\title{
PROPOSIÇÃO DE MÉTODO DE AVALIAÇÃO DE SISTEMAS DE PRODUÇÃO E DE SUSTENTABILIDADE
}

\author{
LUIZ ANTONIO FERRARO JÚNIOR \\ Engenheiro Agrônomo
}

Orientador: Prof. Dr. ANTÔNIO LUIZ FANCELLI

Disscrtação aprescntada à Escola Supcrior dc Agricultura "Luiz de Queiroz", Universidade de São Paulo, para a obtenção do título de Mcstrc $\mathrm{cm}$ Agronomia, Árca dc Concentração: Fitotccnia.

PIRACICABA

Estado de São Paulo - Brasil

Outubro - 1999 
Dados Internacionais de Catalogação na Publicação (CIP)

DIVISÃO DE BIBLIOTECA E DOCUMENTAÇÃO - Campus "Luiz de Queiroz"/USP

Ferraro Junior, Luiz Antonio

Proposição de método de avaliação de sistemas de produção e de sustentabilidade / Luiz Antonio Ferraro Junior. -- Piracicaba, 1999.

$132 p$.

Dissertaçāo (mestrado) - - Escola Superior de Agricultura Luiz de Queiroz, 1999. Bibliografia.

1. Agricultura sustentavel 2. Balanço de energia 3. Milho 4. Segurança alimentar 5. Sistema de produçāo. I. Título

CDD 630.2745 


\section{ERRATA}

Página 9: na 27 ' linha, substituir "investimentoss" e produtoss" respectivamente por "investimentos" e produtos".

Página 11: Suprimir os parágrafos 1 e 2.

Página 15: Na 8' linha, onde está escrito "criação áreas" leia-se "criação de áreas".

Página 47: Na linha 17, coluna E da tabela 6 substituir E17 por E14. Na linha 24, coluna E, substituir E24 por E22.

Página 64: na 20" linha. onde está escrito "alogumas" leia-se "algumas".

Página 90: na 8" linha, onde está escrito "camiminhe" leia-se "caminhe".

Página 92: na $25^{2}$ linha, suprimir a palavra "um" antes de "maiores".

Certamente, outros erros de grafia podem ser encontrados ao longo do texto, o novo sistema de defesa de dissertações e teses, entretanto, não permite a correção após a entrega do texto para a banca. Esta decisão da instituição prejudica a qualidade de muitos textos. Caso o leitor queira utilizar o método pelo EXCELL, atenção às correções sugeridas para a página 47 , sem elas não se obterá um resultado correto. Quaisquer correções que forem julgadas relevantes favor encaminhar ao autor, por carta, no seguinte endereço:

Rua Cap. Jarbas V. de Souza, 161

Jardim São Luís

CEP 14020-470 Ribeirão Preto (SP). 


\section{AGRADECIMENTOS}

À minha esposa por compreender os momentos nos quais não lhe dei a atenção que merece e todo o carinho que o amor que sinto por ela me convida a dar.

Ao Prof. Fancelli pela orientação e disposição para adaptar-se às idas e vindas do processo rico que foi a construção deste trabalho.

Ao Prof. Durval pela co-orientação e atenção sempre cordialmente dispensada.

À CAPES pela bolsa essencial.

Ao Prof. Sorrentino pelo apoio e amizade fundamentais.

Aos colegas e amigos de curso Cris, Oscar, João, Gadioli, Omar, Carlos, Pedro, Marcelo, Renata, Leila, Valéria, pelo companheirismo

Aos bons amigos Marco, André, João, Roberto, Valéria, Mônica, Klaus e Robson pela amizade e estímulo

Ao Rildo, por que se o apoio dado nesta fase fosse melhor, estragava, boa sorte amigo, nas belas aventuras que a vida lhe reserva.

Ao Pessoal da EMBRAPA do Centro Nacional de Pesquisa em Arroz e Feijão pela ajuda imprescindível no campo.

Ao Pessoal da Fazenda Fartura em especial ao Sr. Ricardo Merolla pela cessão de materiais e área para nossa pesquisa

Aos membros da Banca pela atenção dispensada 


\section{DEDICATÓRIA}

Acima de tudo ao meu pai, Luiz Antonio Ferraro, pessoa a quem devo minha vida, meu amor ao mundo, à dignidade, `a justiça, exemplo que me faz sentir que vale a pena continuar e não me omitir. Dedico a ele porque pessoas assim fazem toda a diferença.

À minha mãe, Joênia, e às minhas irmãs, Gabriela e Juliana, seres humanos lindos e íntegros, mulheres emancipadas eguerreiras, têm minha admiração e orgulho eternos.

À minha esposa, Anapaula, pelo coração transbordante de amor e paz e a alma limpa que os olhos revelam. 


\section{SUMÁRIO}

Página

RESUMO

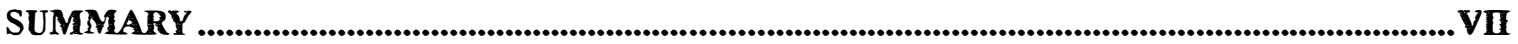

1. INTRODUÇÃO

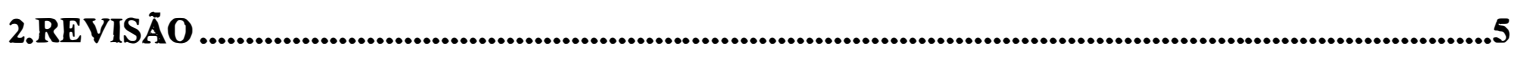

2.1 ESTADO DA ARTE RELACIONADO AOS CONCEITOS DA SUSTENT ABILIDADE NA AGRICULTURA...........5

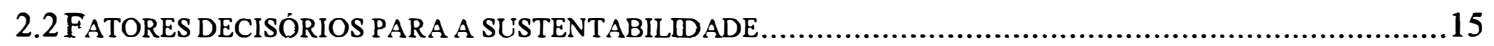

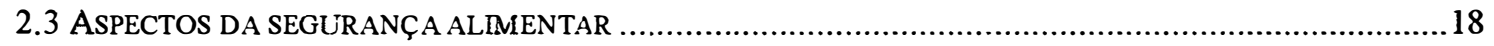

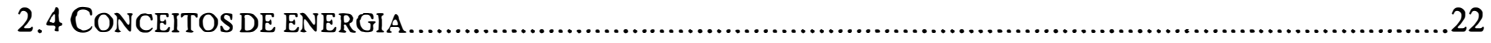

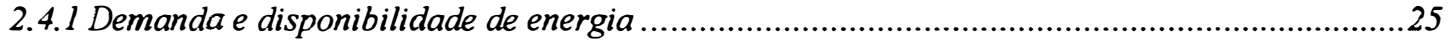

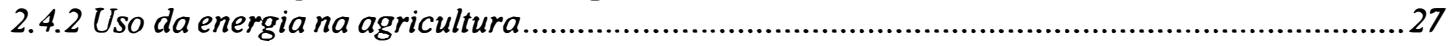

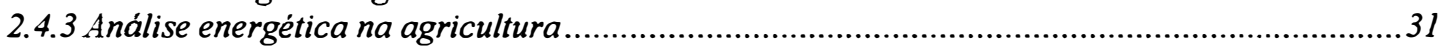

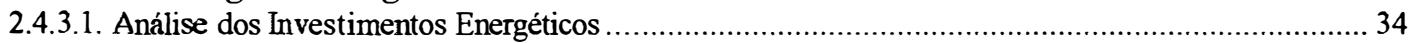

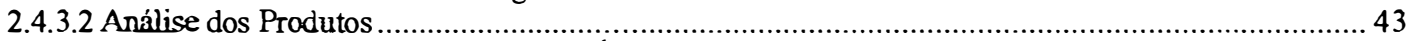

2.4.3.3. Apresentação dos Resultados ou Índices Energéticos ............................................................ 44

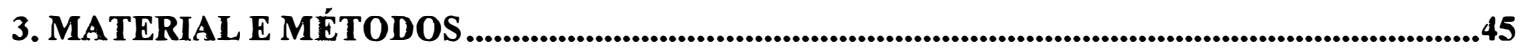

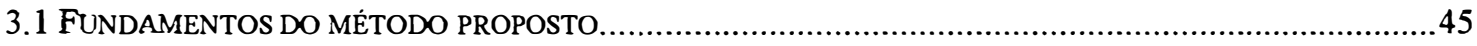

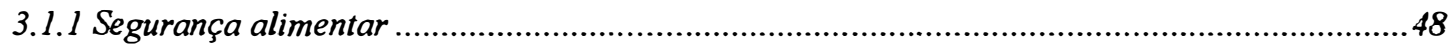

3.1.1.2 Índice de Eficiência do Sistema para Segurança Alimentar (S) .................................................. 50

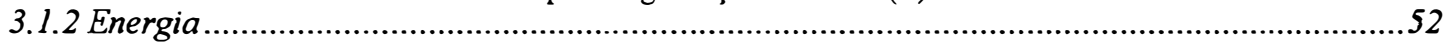

3.1.2.1 Proposta de roteiro para a elaboração da análise energética …..................................................... 54

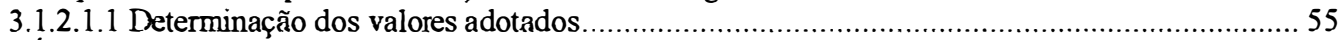

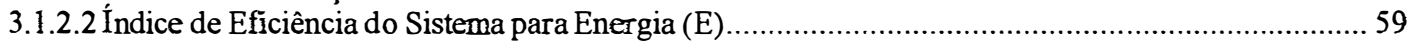

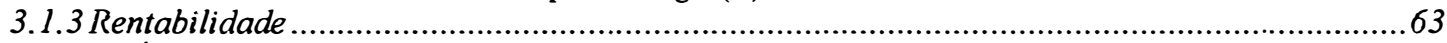

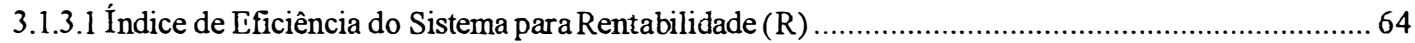

3.1.4 Pressupostos para a validade dos parâmetros do método .......................................................64

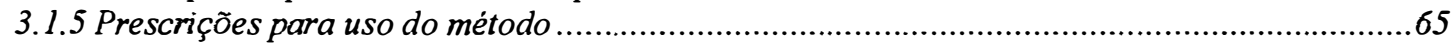

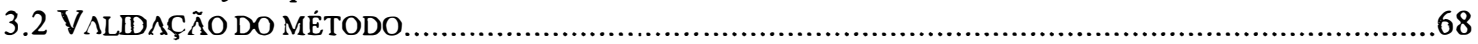

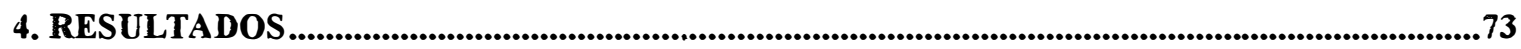

5. DISCUSSÕES

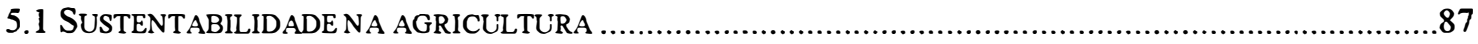

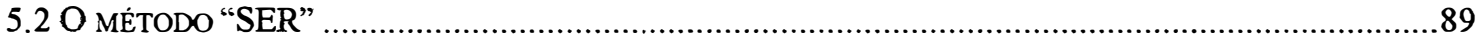

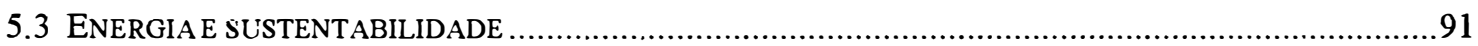

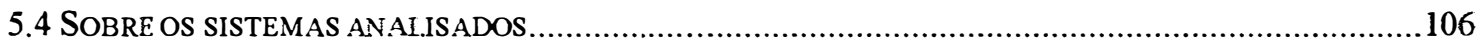

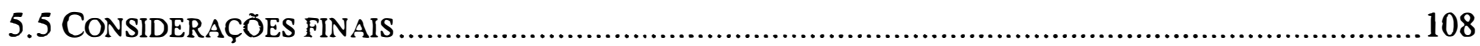

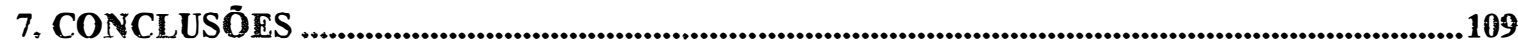

6. BIBLIOGRAFIA ….........................................................................................................................110

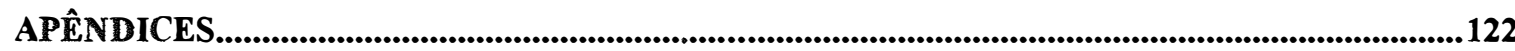




\section{LISTA DE TABELAS}

Página

Tabela 1 : Classes de sustentabilidade propostas no FESLM ............................................... 12

Tabela 2: Fatores de qualidade de energia.............................................................................. 24

Tabela 3: Reservas de petróleo e tempo para depleção total .......................................................... 26

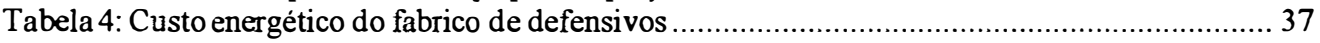

Tabela 5: Custo energético para diversas operações .............................................................. 40

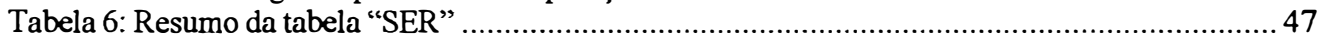

Tabela 7: Consumo energético segundo níveis de demanda .............................................. 48

Tabela 8: Produção de energia por hectare para níveis de consumo............................................ 49

Tabela 9: Consumo protéico segundo níveis de demanda ............................................... 49

Tabela 10: Produção de proteína por hectare para níveis de consurno......................................... 50

Tabela 11: Produtividade atual e potencial para diferentes culturas.......................................... 51

Tabela 12: Potencial da cultura do milho para atender às demandas .......................................... 52

Tabela 13: Fatores de conversão de energia para insumos diversos ...................................... 58

Tabela 14: Fatores de conversão de energia para serviços diversos .......................................... 59

Tabela 15: Fatores de conversão de energia para sistemas de irrigação em função do recalque ......... 57

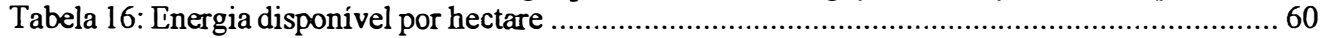

Tabela 17: Custo de oportunidade da terra em fumção de preço e taxas de juros............................. 63

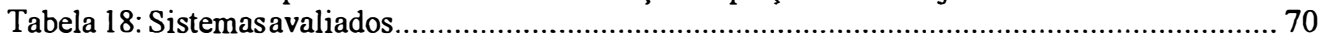

Tabela 20: Critérios para diferentes níveis de fertilização................................................... 71

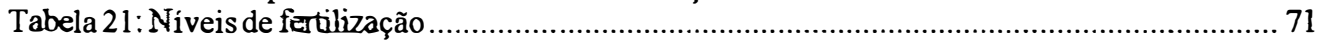

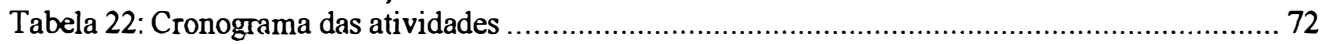

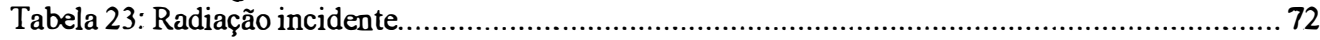

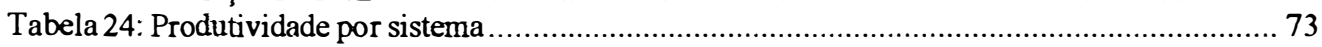

Tabela 25: Custo de produção do sistema com gradagem e adubação EG...................................... 74

Tabela 26: Custo de produção do sistema com plantio direto e adubação EG .............................. 75

Tabela 27: Custo de produção do sistema com Gradagem e ałubação T .................................... 76

Tabela 28: Custo de produção do sistema com plantio direto e adubação T ................................... 77

Tabela 29: Análise energética do sistema com Gradagem e adubação EG .................................. 78

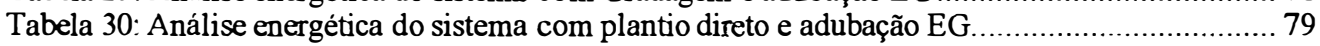

Tabela 31: Análise energética do sistema com Gradagem e ađubação T...................................... 80

Tabela 32: Análise energética do sistema com plantio direto e adubação $\mathrm{T}$................................. 81

Tabela 33: Análise do método "SER" para a avaliação do sistema com Gradagem e adubação EG ... 82

Tabela 34: Análise do método "SER" para a avaliação do sistema com Plantio direto e adubação EG83

Tabela 35: Análise do método "SER" para a avaliação do sistema com Gradagem e adubação T ...... 84

Tabela 36: Análise do método "SER" para a avaliação do sistema com Plantio direto e adubação T . 85

Tabela 37-: Resumo das tabelas "SER" .......................................................................... 86

Tabela 38: Fatores de conversão de energia para diferentes operações mecânicas..........................102

\section{FIGURA}

Figura 1: ESTRUTURA TEÓRICA DA METODOLOGIA....................................................... 46 


\title{
PROPOSIÇÃO DE MÉTODO DE AVALIAÇÃO DE SISTEMAS DE PRODUÇÃO E DE SUSTENTABILIDADE
}

\author{
Autor: Luiz Antonio Ferraro Júnior \\ Orientador: Prof. Dr. Antônio Luiz Fancelli
}

\section{RESUMO}

O presente trabalho propõe uma metodologia para a avaliação de sistemas de produção de modo a aferir sua sustentabilidade.

O método fundamentou-se no reconhecimento da necessidade do desenvolvimento da agricultura sustentável a partir da realidade, na constatação de que não existem modelos prontos de sustentabilidade e que as alterações do processo agrícola dependem fundamentalmente das decisões do agricultor.

A sustentabilidade, como vem sendo exaustivamente debatido nos mais diversos meios, depende de aspectos sociais, ambientais e econômicos; a metodologia para análise proposta neste trabalho interpretou estes como Segurança alimentar, Energia e Rentabilidade respectivamente, compondo assim o método denominado "SER".

Fundamentado nestes conceitos o referido trabalho propõe equações e valores numéricos como instrumentos de análise. Após a validação do método, fundamentada na avaliação de quatro sistemas de produção, concluiu-se que:

a) A análise dos índices e da planilha energética propostos podem orientar 0 processo de tomada de decisão de agricultores e técnicos, no sentido de promover 
alterações ou inovações no sistema de produção objetivando o aumento do grau de sustentabilidade.

b) $\mathrm{O}$ método proposto possibilita a adequada avaliação do grau de sustentabilidade de sistemas de produção, fornecendo um índice "multifuncional" para a sua respectiva análise. 


\title{
PROPOSAL OF A FRAMEWORK TO EVALUATE PRODUCTION SYSTEMS AND SUSTAINABILITY
}

\author{
Author: Luiz Antonio Ferraro Júnior \\ Adviser: Prof. Dr. Antônio Luiz Fancelli
}

\section{SUMMARY}

This work has proposed a framework to evaluate production systems towards sustainability. The framework was based on the recognition that sustainable agriculture must be developed up to the reality, that the practice of sustainable agriculture has no models available and that the changes in the agriculture process depend basically on the farmer decisions.

Generally, the concepts on sustainability consider that this goal must be reached through three aspects: social, environmental and economical aspects. The proposed method has interpreted it as food security, energy and profitability, respectively. The framework has been called "SER", a combination of those words in Portuguese.

Based on these parameters, this work developed equations looking for indices to evaluate the system efficiency in terms of ffod security, energy and profitability; and values of energy conversion from different inputs. Another attribute of this approach is the continuous improvement through its application by its users, introducing new data into the system.

The proposed framework was applied to four agricultural production systems; 
with two different land managements and two fertilization levels, and the conclusion were:

a) The indices and energy analysis proposed are able to guide, farmers and specialists, by their decision process towards the sustainability level improvement;

b) The framework evaluates adequately the sustainability level of production systems by analysing it through multifunctional parameters. 


\section{INTRODUÇÃO}

A questão da sustentabilidade da agricultura e da sociedade vem inquietando técnicos, agricultores, acadêmicos e a sociedade em geral, sem que se saiba que rumo seguir. Muitas pessoas têm erguido bandeiras na defesa de sistemas de produção alternativos como sendo as alternativas para a sustentabilidade. Alguns conceitos ecológicos costumam fundamentar estas apaixonadas defesas, mas certamente não se pode afirmar que espelham toda a verdade. Existe a necessidade de encontrar maneiras de analisar sistemas de produção além da paixão ou da economicidade. Este trabalho discute estas questões e propõe um método para isto.

A partir do século XIX a sociedade ingressou em uma era de modernização que influenciou a maior parte das áreas do conhecimento e atividades humanas. As modificações na sociedade como um todo ocorreram com uma velocidade jamais vista. Consequentemente, as relações humanas, em seus aspectos sócio - econômicos, atingiram enorme complexidade; os indivíduos não mais puderam conhecer e compreender as redes de atividades e pessoas relacionadas aos bens e serviços que cercavam suas vidas. Processos sobrepuseram-se a processos para a obtenção de produtos cada vez mais elaborados. Como resultado surgiu a necessidade do desenvolvimento de fundamentos teóricos para possibilitar o conhecimento do valor incorporado aos bens e serviços. As teorias de valor econômico foram elaboradas a partir do estudo detalhado dos processos. Não foram capazes, entretanto, de valorar adequadamente a ética ou a natureza.

Os mecanismos de mercado levam à desvalorização de qualquer recurso que seja abundante, seja ele qual for, até que este recurso torne-se escasso em virtude do uso ineficiente. Isto ocorreu durante quase dois séculos com os recursos água, solo, minerais 
e energéticos. Dentro deste panorama desenvolveu-se a agricultura moderna e à ela foi dada a missão de garantir segurança alimentar e liberar mão-de-obra para o desenvolvimento urbano - industrial.

Os sistemas de produção desenvolveram-se sob uma ótica produtivista na qual não se atentou à otimização de recursos baratos. Toda a agricultura, que é constituída de processos físicos, químicos e biológicos foi modificada segundo processos de mercado seguindo parâmetros exclusivamente econômicos.

$\mathrm{O}$ custo desse processo foi a perda de recursos naturais e a formação de uma agricultura economicamente eficiente mas "biofisicamente" falha. Além de utilizarmos insumos em excesso e indiscriminadamente, a redução da biodiversidade advinda da monocultura e do manejo com controle de invasoras, pragas e doenças aumentou a entropia do processo agrícola em virtude da maior instabilidade dos sistemas de produção. A estabilização da produção depende cada vez mais da entrada (investimentos energéticos) de recursos com entropia baixa, ou seja, fontes energéticas com energia de alta disponibilidade (energia elétrica, combustíveis, agroquímicos).

Soma-se a isto a tendência global da busca por modelos sustentáveis de agricultura. A transição para a sustentabilidade pressupõe a identificação de sistemas eficientes a longo prazo. Avaliações meramente financeiras de sistemas têm um horizonte demasiadamente curto pois estão sujeitas a distorções impostas pelas flutuações do mercado, o que não é o caso das avaliações em torno dos fluxos de energia.

Através de uma simplificação comparativa pode-se afirmar que o sol é o salário energético da sociedade e as reservas fósseis suas poupanças. Para investir na construção da sociedade moderna fez-se uso intensivo dessas reservas, cabe agora aprender a viver só com o recursos que possamos utilizar no longo prazo, o sol.

Uma abordagem da questão sugere que a agricultura deva antes de mais nada atender às necessidades da população, sem comprometer a possibilidade de que no futuro também possam ser atendidas. Esta necessidade pode ser traduzida como atender à segurança alimentar a curto, médio e longo prazo. Para isso, o agricultor deve encontrar em sua atividade uma rentabilidade que o mantenha participante do processo 
agrícola.

Um instrumento importante para que engenheiros agrônomos, florestais, agricultores e outros profissionais do setor otimizem os processos na agricultura, de modo a permitir o seu desenvolvimento sustentável, é a análise energética de sistemas de produção .

Os economistas que orientam nossas políticas de desenvolvimento estão afastados dos conceitos da ecologia e encontram por interlocutores ecologistas desinteressados da economia. O fruto desta associação infeliz é a crença na tecnologia, e na substituição de tecnologias, baseada em recursos não-renováveis por outras fundamentadas em recursos renováveis através de uma transição calma, simples e imperceptível. A taxa de substituição seria controlada pelo mercado e as leis de oferta e demanda. O Brasil tem imenso potencial hidroelétrico mas vivemos à sombra de blecautes. O que aconteceria se o país passasse a depender $100 \%$ deste tipo de energia? Os perigos advindos da lentidão na taxa de substituição dessa energia na agricultura podem ser a inviabilidade do atual modelo de produção e a conseqüente perda das últimas conquistas da agricultura, principalmente da segurança alimentar. O risco deste tipo de involução é o da involução da própria sociedade, que mergulharia em um caos, em uma barbárie de famintos. Pode-se jogar dados com o destino da humanidade? "Mas afinal, "há diferença entre encontrar-se nas terra, seres humanos com suas ânsias espiritais ou bactérias banhando-se ao sol?" pergunta-se Herman Daly em seu livro "Economia, Ecologia e Ética"; apesar de a parentemente apelativas, estas duas questões são as principais que envolvem a disposição de técnicos e agricultores em repensar os atuais sistemas de produção.

O setor agrícola e a classe agronômica têm que encontrar caminhos para uma otimização da agricultura que atenda tanto à manutenção da segurança alimentar, quanto à economicidade da atividade e à eficiência energética dos sistemas de produção. Os movimentos rebeldes, como Agricultura Orgânica, Permacultura, Agricultura Biodinâmica e Agricultura Natural propõem sistemas de produção pouco aplicáveis à toda sociedade, nas condições atuais de urbanização e industrialização, e que podem colocar em jogo o abastecimento da população. A agricultura sustentável por sua vez 
permanece como conceito teórico abstrato, obscuro até mesmo dentro do meio acadêmico. Técnicas e tecnologias agrícolas como plantio direto, rotação de culturas, adubação verde, controle biológico de insetos, consorciação de culturas, tração animal e uso de resíduos invariavelmente melhoram o balanço energético dos sistemas de produção. A escolha de técnicas, tecnologias e o delineamento de sistemas de produção não podem seguir critérios puramente econômicos, ou antes, os critérios devem assimilar outros valores, principalmente quanto aos recursos naturais.

Várias constatações levaram à escolha do tema deste trabalho, destacamos: a) Há a necessidade de que se desenvolvam sistemas de produção sustentáveis; b) Sustentabilidade tem permanecido como conceito teórico; c) Não existem indicadores para orientar a tomada de decisões para a sustentabilidade; d) Energia é um indicador muito consistente para se avaliar a sustentabilidade; e) Produtividade e lucratividade são indispensáveis à sustentabilidade na agricultura e f) Os benefícios de um processo de diagnose participativa ocorrem ao longo do próprio processo e não apenas através de seus resultados.

Este trabalho tem por objetivo avaliar o estado da arte da sustentabilidade na agricultura e através deste estudo, fundamentar uma nova metodologia que torne objetivas as questões teóricas concernentes à sustentabilidade e possibilite assim avaliar sistemas de produção com este fim. Propõe-se a contribuir com a agricultura e com a sociedade através da elaboração de um método de avaliação de sistemas de produção que :a) Avalie com razoável confiabilidade e simplicidade a sustentabilidade do sistema de produção para orientar os tomadores de decisão; b) Ofereça um índice de sustentabilidade da cultura ou da propriedade para a sociedade e c) Estimule, através de sua aplicação, o pensar global do agricultor e de técnicos do setor. 


\section{REVISĀO}

\subsection{Ostado da arte relacionado aos conceitos da sustentabilidade na agricultura}

$\mathrm{Na}$ literatura, não se encontra uma definição operacionalmente útil do que seja "sustentabilidade" da agricultura. A palavra "sustentabilidade" tem forte conotação valorativa: reflete mais uma expressão dos desejos e valores de quem a exprime do que algo concreto, de aceitação geral. Em razão disso, as definições correntes são vagas e amplas o suficiente para englobar o máximo de condições que se possam requerer do processo de desenvolvimento (Cunha, 1994).

O conceito de sustentabilidade implica uma perspectiva, um critério geral no que se refere às relações básicas da organização social, mais do que um conjunto concreto e específico de ações a serem empreendidas por indivíduos ou organizações públicas e privadas de uma sociedade em particular (Trigo et al., 1994).

Assim, ao se falar de desenvolvimento sustentável é preciso reconciliar aspectos econômicos e sociais com as dimensões biofísicas referentes aos recursos naturais e à própria capacidade dos distintos ecossistemas em responder à demanda a que lhes submetem as sociedades humanas (Girt, 1990). O sentido do termo sustentável é buscar melhorar a qualidade de vida humana, respeitando a capacidade de suporte dos ecossistemas que a mantém (Alho, 1992).

Trigo et al. (1994) cita a Comissão Brundtland ("Our common Future") segundo a qual "Desenvolvimento sustentável procura satisfazer as necessidades do presente sem comprometer a capacidade das gerações futuras alcançarem suas próprias necessidades." 
Segundo Benbrook (1994) define-se como agricultura sustentável a produção de alimentos e fibras por um sistema que aumenta a capacidade produtiva inerente dos recursos naturais e biológicos em sintonia com a demanda, enquanto proporciona lucros adequados aos agricultores, fornece alimentos saudáveis aos consumidores e minimiza os impactos adversos sobre o meio ambiente e a saúde dos trabalhadores rurais e animais. Os sistemas de agricultura sustentável constituem um objetivo que todos os agricultores devem empenhar-se por realizar, e os experimentos com sistemas agrícolas alternativos são um meio comprovadamente eficaz de se atingir esse fim.

Outro conceito importante define agricultura sustentável como o manejo bem sucedido de recursos para a agricultura, de modo a satisfazer as necessidades humanas em transformação, mantendo ou melhorando, ao mesmo tempo, a qualidade do ambiente e conservando os recursos naturais (TAC/CGIAR, 1988 citado por Comine \& Müller, 1993).

Com base nas definições conhecidas sobre agricultura sustentável, pode-se observar que todas incorporam os seguintes itens: "manutenção a longo prazo dos recursos naturais e da produtividade agrícola; o mínimo de impactos adversos ao ambiente; retornos adequados aos produtores; otimização da produção das culturas com o mínimo de insumos químicos; satisfação das necessidades humanas de alimentos e de renda; atendimento das necessidades sociais das famílias e das comunidades rurais" (NRC, 1991).

De acordo com a FAO (1991), a agricultura e o desenvolvimento rural sustentáveis podem ser definidos como "o manejo e a conservação da base de recursos naturais, e a orientação da mudança tecnológica e institucional, de maneira a assegurar a obtenção e a satisfação das necessidades humanas para as gerações presentes e futuras".

Segundo a declaração de Den Bosch de 1992 que expressa o conceito para a FAO: "Agricultura sustentável é o manejo e conservação dos recursos naturais e a orientação de mudanças tecnológicas e institucionais de tal maneira a assegurar a satisfação de necessidades humanas de forma continuada para as gerações presentes e futuras. Tal desenvolvimento sustentável conserva o solo, a água e recursos genéticos 
animais e vegetais; não degrada o meio ambiente; é tecnicamente apropriado, economicamente viável e socialmente aceitável".

A sustentabilidade da agricultura e dos recursos naturais, segundo o ICA (1992), se refere ao uso dos recursos biofísicos, econômicos e sociais segundo sua capacidade, em um espaço geográfico, para, mediante tecnologias biofísicas, econômicas, sociais e institucionais, obter bens e serviços diretos e indiretos da agricultura e dos recursos naturais para satisfazer as necessidades das gerações presentes e futuras. $O$ valor presente dos bens e serviços deve representar mais que o valor das externalidades e dos insumos incorporados, melhorando ou pelo menos mantendo de forma indefinida a produtividade futura do ambiente biofisico e social. Além do mais, o valor presente deve estar eqüitativamente distribuído entre os participantes do processo.

Altieri (1989) integra a produtividade dos sistemas agrícolas a aspectos econômicos, sociais e ambientais, referindo-se à sustentabilidade como "a habilidade de um agroecossistema em manter a produção através do tempo, face a distúrbios ecológicos e pressões sócio-econômicas de longo prazo".

Um sistema deveria ser considerado insustentável, segundo Altieri (1993), quando acusa-se: redução da capacidade produtiva provocada por erosão ou contaminação dos solos por agrotóxicos; redução da capacidade homeostática, tanto nos mecanismos de controle de pragas quanto nos processos de reciclagem de nutrientes; redução da capacidade evolutiva do sistema, em função da erosão genética ou da homogeneização genética provocada pelas monoculturas; redução da disponibilidade e qualidade de recursos que atendam necessidades básicas (acesso a terra, água) e redução da capacidade de utilização adequada dos recursos disponíveis, principalmente devido ao emprego de tecnologias impróprias.

Segundo Maloouf (1993) as causas básicas da insustentabilidade são degradação do solo, disponibilidade limitada de água, esgotamento de outros recursos naturais, pobreza, crescimento rápido da população e diminuição da força de trabalho agrícola. Segundo o mesmo autor, as estratégias para o desenvolvimento agrícola sustentado devem focalizar cinco áreas de ação: a) utilização eficiente de tecnologias adequadas e 
com boa relação custo/benefício b) melhoria da infra-estrutura rural c) disponibilidade de fundos de investimento para insumos e serviços agrícolas d) desenvolvimento do conhecimento, atitude e técnicas dos fazendeiros e) pesquisas de tecnologias agrícolas avançadas e ambientalmente adequadas.

No Brasil, o termo agricultura "auto-sustentável" foi definido por Flores et al. (1991) como sendo: "uso de tecnologias adequadas às condições do ambiente regional e mesmo local, e da previsão e prevenção dos impactos negativos, sejam eles sociais, econômicos e ambientais. O objetivo final é a garantia de que os agroecossistemas sejam produtivos e rentáveis ao longo do tempo, conseguindo para tanto uma certa estabilidade dos fatores de produção, os quais nem sempre são facilmente manejáveis, pois são influenciados pelo mercado, por aspectos sociais e culturais e pelas condições climáticas características de cada realidade regional".

De um modo geral, percebe-se que a agricultura sustentável será, provavelmente, uma evolução do atual modelo de produção agrícola, em uma direção que ainda não está clara, mas que certamente combinará práticas convencionais e alternativas; porém, não se constituirá de um conjunto bem definido de práticas, como foi o pacote tecnológico da Revolução Verde, pois cada agroecossistema apresenta características distintas e requer manejos específicos (Ehlers, 1996).

A teoria neoclássica tem servido de base para alguns economistas buscarem sistemas com conceitos, métodos e técnicas para a valoração ambiental, acreditando que através da valoração econômica de recursos naturais seu uso será otimizado em direção à sustentabilidade. Segundo Marques \& Comune (1997) existem três correntes de economistas trabalhando nesta direção: a primeira é a da economia do meio ambiente e dos recursos naturais, que baseia-se nos fundamentos da teoria neoclássica; a segunda é a da economia ecológica que fundamenta-se nas leis da termodinâmica e busca valorar os recursos naturais com base nos fluxos de energia líquida dos ecossistemas e por último encontramos uma corrente chamada economia institucionalista que procura abordar o problema pelo ponto de vista dos custos de transação incorridos pelos elementos do ecossistema (instituições, comunidades, agências, públicos em geral), na 
busca de uma determinada qualidade ambiental.

Para os economistas ecológicos a valoração econômica apoiada na economia neoclássica não se aplica a bens e serviços ecológicos que são de longo prazo, além de não incorporarem as futuras gerações e não fazerem qualquer menção a valores sobre os quais não podemos compreender toda sua importância. A proposta que fazem para avaliar os serviços ecológicos é a análise energética, um método com base biofísica. Segundo os economistas neoclássicos esta abordagem não contempla as hipóteses da soberania do consumidor. O que é certo para qualquer estudioso da sustentabilidade é que o meio ambiente possui valor econômico não refletido pelo funcionamento de mercado. A abordagem ecológica pressupõe que os limites ao crescimento, baseados na escassez de recursos não são necessariamente superáveis por evoluções da tecnologia (Daly, 1992). Não considerar seu valor pode implicar em um uso excessivo e na sua degradação. Para Marques \& Comune (1997) meio ambiente e sistema econômico interagem, através dos impactos da economia no ambiente e dos recursos naturais na economia. A falta de informações confiáveis, quanto a essas interações entre economia e natureza, implica na necessidade de elaborar-se métodos para avaliar os bens e serviços obtidos através dos ecossistemas. Segundo May (1997), são preferidos métodos construtivos de valoração, estruturados para poder informar aos atores sociais do conteúdo e finalidade do processo. Há portanto um consenso quanto à idéia de que devemos avaliar, de alguma maneira, os serviços prestados pelos ecossistemas.

Também existem, baseadas nestes parâmetros, discussões sobre políticas públicas voltadas para a sustentabilidade. Sobre isso abordaremos alguns comentários no decorrer do texto.

Ehrlich (1994) citado por Begossi (1997) considera como principais desafios à economia ecológica a educação e o estabelecimento de uma sociedade sustentável, para a qual é necessário: adaptar a teoria de alocação de recursos, para relacionar os investimentoss e produtoss físicos e biológicos ao sistema econômico; incorporar aos serviços provenientes do funcionamento dos ecossistemas, os cálculos econômicos; incluir os conceitos de eqüidade e energia em indicadores de eficiência econômica; e 
incluir os fatores ambientais na contabilidade nacional. Reforçando a interface entre a economia ecológica e a educação, esta corrente é vista como uma das principais linhas de educação ambiental, segundo Leonardi (1997) citando Sorrentino (1995), o conceito de valorização do pequeno de Schumacher (1977) e documentos importantes como "Nosso Futuro Comum" (Comissão Brundtland, 1987). Segundo a autora, a esta quarta corrente incluem-se ONGs e ambientalistas que defendem tecnologias alternativas de uso da terra, de uso da energia e no tratamento de resíduos. Ecologia é o conhecimento de nossa casa e, economia o manejo dela; estas duas ciências são etmológica e fundamentalmente indissociáveis; para que o manejo da casa seja feito de acordo com conhecimentos das ciências é necessário que este conhecimento seja partilhado, que todos possam participar da discussão sobre como a "casa" deva ser gerenciada. Partilha de conhecimentos, democratização do saber, participação nas escolhas são pressupostos que não devem ser esquecidos na agricultura sustentável. $O$ desenvolvimento participativo de tecnologias é um dos passos fundamentais para que se possa respeitar as diferenças locais de ambiente e cultura, passo necessário à construção do processo desta nova agricultura.

Há, indubitavelmente, a necessidade da superação do atual paradigma produtivista, que deve ser suplantado por um novo paradigma centrado em diversos aspectos de qualidade e quantidade, o padrão para a agricultura deverá ser multifuncional segundo Romeiro \& Salles Filho (1997). Por isso entende-se que o processo agrícola não deverá ser orientado apenas pelas funções de produtividade e rentabilidade mas também incluir aspectos ambientais e sociais, usualmente excluídos do processo decisório. De modo geral, sabe-se que alguns pontos críticos têm contribuído para a insustentabilidade dos sistemas. O chamado sistema convencional apresenta como características o intenso uso de máquinas, diversas atividades de preparo do solo, uso de agroquímicos para proteção vegetal e homogeneização do sistema; os problemas provenientes dessas práticas, têm prejudicado a manutenção da produtividade.

Assim, o presente trabalho, busca identificar, com maior precisão, esses temas que, de modo geral, parecem indicar os caminhos para a sustentabilidade da agricultura. 
Veiga (1994) observa que, em geral, todas as definições de agricultura sustentável incorporam os seguintes itens: a) Manutenção a longo prazo dos recursos naturais e da produtividade agrícola; b) Mínimo de impactos adversos ao ambiente; c) Retornos adequados aos produtores; d) Otimização da produção com minimização de insumos químicos; e) Satisfação das necessidades humanas de alimentos e renda e f) Atendimento das necessidade das comunidades e famílias rurais.

Um sistema de produção, ou agroecossistema é considerado insustentável por Altieri (1989), caso tenha reduzida: sua capacidade produtiva em virtude de erosão ou contaminação dos solos, sua capacidade homeostática, nos mecanismos de controle de pragas e reciclagem de nutrientes, sua capacidade evolutiva, em virtude da erosão genética provocada pelas monoculturas, sua disponibilidade e qualidade de recursos essenciais como terra e água, sua capacidade de utilização correta dos recursos disponíveis, principalmente pelo uso de tecnologias impróprias.

A agricultura só é sustentável quando é ecologicamente correta, economicamente viável e socialmente justa, Gips (1986). Reijntjes et al. (1994) consideram como essenciais à construção da agricultura sustentável a: Otimização da disponibilidade e reciclagem de nutrientes; Manejo dos fluxos de radiação solar, água e ar; O aproveitamento da sinergia e complementariedade na combinação de recursos genéticos; A redução das perdas por pragas e doenças; e, O desenvolvimento participativo de tecnologias.

De modo geral uma agricultura mais equilibrada ecologicamente deveria substituir fertilizantes químicos de alta solubilidade por outros de menor solubilidade ou por fertilizantes orgânicos, deveria haver substituição de defensivos químicos por biológicos e a mudança radical de equipamentos de preparo do solo em direção ao plantio direto, Romeiro \& Salles Filho (1997).

Uma metodologia para análise da sustentabilidade do manejo de solo (FESLM) elaborada por Smyth \& Dumanski (1995); propõe que, um sistema de manejo de solo deve: a) Manter ou melhorar a produção (Produtividade); b) Reduzir os riscos da produção (Segurança); c) Proteger os recursos naturais e prevenir degradação do solo e da água (Proteção); d) Ser economicamente viável (Viabilidade) e e) Ser socialmente 
aceitável (Aceitabilidade).

Esses cinco objetivos seriam, segundo os autores os pilares da sustentabilidade do manejo de solo. Os mesmos autores identificam seis classes para a sustentabilidade conforme a Tabela 1 .

Tabela 1 : Classes de sustentabilidade propostas no FESLM

\begin{tabular}{llc}
\hline & CLASSE & $\begin{array}{c}\text { LIMITES DE } \\
\text { CONFIANÇA }\end{array}$ \\
\hline \multirow{2}{*}{ SUSTENTÁVEIS } & 1. Sustentável a longo prazo & $>25$ anos \\
& 2. Sustentável a médio prazo & $15-25$ anos \\
& 3. Sustentável no curto prazo & $7-15$ anos \\
INSUSTENTÁ VEIS & 4. Levemente insustentável & $5-7$ anos \\
& 5. Moderadamente insustentável & $2-5$ anos \\
& 6. Altamente insustentável & $<2$ anos \\
\hline
\end{tabular}

Fonte: Smyth \& Dumanski (1995)

Outro enfoque importante relacionado à sustentabilidade na agricultura relaciona-se à relação causas e efeitos ambientais na sociedade com origem no setor agrícola. Destaca-se aí a contribuição do setor agrícola para o efeito estufa, estimada em 14\% por Lashof e Tirpak (1990) citados por Goldemberg (1998). Co-relacionadas estão o efeito de produção de energia sobre o efeito estufa (57\%) e do desmatamento (9\%) segundo os mesmos autores. Ao demandar energia em formas prontamente disponíveis como combustíveis, máquinas, eletricidade e outros insumos, a agricultura contribui para o processo de emissão de carbono na atmosfera, que é o principal gás estufa, além disso as expansões de área através de desmatamento também aumentam a emissão de gases associada ao processo agrícola.

É fácil chegar a um consenso quanto à sustentabilidade como um objetivo de longo prazo para a agricultura (Benbrook,1994). Contudo, no âmbito da propriedade agrícola, os agricultores têm de reagir a um sem-número de fatores prementes, muitos dos quais atuam no curto prazo. Nestes fatores, dentre muitos outros, incluem-se os mercados, preços dos insumos, condições climáticas, regras governamentais, tecnologia disponível, custo de mão de obra, acesso a profissionais especializados, capital disponível e assim por diante. Quando um agricultor é levado à falência pela queda dos 
preços de seus produtos, o funcionamento da propriedade torna-se financeiramente insustentável; mas quando os prejuízos com a colheita crescem devido a excessiva erosão ou salinidade do solo, ou ainda em razão de um colapso nos métodos de controle de insetos, o sistema agrícola é tão financeiramente insustentável quanto no caso da falência, embora por motivos diferentes (Benbrook, 1994).

Segundo Trigo et al. (1994) citando documento do Banco Mundial (1990), um elemento essencial para o desenvolvimento sustentável da agricultura é o investimento em atividades produtivas de longa maturação, tais como o reflorestamento, os cultivos perenes, a conservação de solos e outras. Nas condições econômicas atuais é muito menos rentável fazer investimentos a longo prazo do que era no passado. Uma razão para isso se encontra nas taxas de juros reais. No plano internacional elas subiram de uma média de 2,64\% ao ano entre 1963 e 1973 à média de 5,85\% entre 1980 e 1989; no Brasil os juros anuais hoje em dia estão em torno de $16 \%$ ao ano com prazo de pagamento de 12 meses. Nessa situação é impossível; estimular o produtor rural a investir em atividades que só darão frutos a médio ou longo prazo. Outro fator que inibe o investimento produtivo de longo prazo é a magnitude da variação dos níveis de inflação de ano para ano, sendo em geral acompanhadas de mudanças significativas dos preços relativos.

As políticas de abertura comercial, atualmente em voga, são outro aspecto que requer uma análise cautelosa; se não forem complementadas por esquemas que assegurem a expressão das internalidades negativas e positivas de certas atividades, corre-se o risco de gerar efeitos negativos sobre os recursos naturais e o meio ambiente na busca da competitividade sem que estes efeitos sejam externados para a sociedade e para os tomadores de decisão a tempo de reparar-se esses erros. O mercado é um instrumento poderoso para orientar a atividade econômica e promover o crescimento, mas se não forem incorporadas reformas que venham garantir que os preços efetivamente reflitam as limitações de longo prazo, corre-se o risco de cair na ilusão de um crescimento baseado na extração de recursos, e não na criação de uma competitividade real (Trigo et al., 1994).

O presente conceito de agricultura sustentável, segundo Bird \& Ikerd (1994), 
requer viabilidade de um modelo de unidade agrícola do tipo "family farm" (propriedade familiar) no século XXI. Os atributos estruturais desse modelo são: a) A unidade agrícola é operada pelo proprietário; b) Os dias de trabalho da mão-de-obra contratada não excedem os dos membros da família de agricultores; c) A unidade agrícola é, em geral, uma sociedade de no máximo, três famílias; d) A unidade agrícola é estruturada como uma relação conjunta entre administradores e trabalhadores; e) A unidade agrícola diversificada; f) Há ênfase no uso de recursos obtidos na própria unidade produtora; g) Comumente, as tomadas de decisões realizam-se no próprio local e em tempo real; h) Existe um conjunto diversificado de posturas empresariais.

As posturas empresariais associadas a esse modelo abordam o tipo de sistema de produção, objetivos econômicos, objetivos concernentes à qualidade ambiental, objetivos de conservação de recursos naturais e objetivos de qualidade de vida.

Políticas públicas errôneas ou "top-down" orientadas podem gerar graves crises políticas ou econômicas, ou ainda serem simplesmente ignoradas. Podem, inclusive como já relatado no Brasil na década de 70, estimular o agricultor a um uso excessivo ou inadequado de insumos "modernos".

Existem diversos instrumentos de políticas públicas para a agricultura que permitem, de forma geral, contribuir para modificações que podem ser associadas aos conceitos genéricos de sustentabilidade. Estes instrumentos, sejam eles de ordem macroeconômica, setorial, jurídica ou político social devem ser difundidos e implementados sem que se pese apenas os aspectos econômicos destas políticas.

Um resumo das políticas para a sustentabilidade pode ser encontrado no quadro organizado por Trigo et al.(1994) exposto no apêndice 3.

Políticas de ordem macroeconômica como desvalorização e redução das taxas de juro podem contribuir para que fique mais rentável investir em agricultura, menos rentável usar capital importado, fique viável investir em atividade de longa maturação.

Políticas como financiamento da atividade estatal, adequação de impostos, e reserva de recursos para para implementar políticas de sustentabilidade também podem contribuir para a sustentabilidade na agricultura.

Instrumentos de políticas setoriais como eliminar controle de preços de alimentos 
subsídio ao crédito para práticas sustentáveis, maior investimento em conservação dos solos, culturas perenes, taxar água de irrigação, Não subsidiar desmatamento e agroquímicos, Evitar construir estradas de colonização, Subsidiar replantio de florestas naturais.

Políticas de ordem jurídica são extremamente relevantes para a reorientaçào do uso de recursos e para conservação de solos e biodiversidade. São exemplos de instrumentos desta linha de política para a sustentabilidade a titulação de terras e garantia de propriedade, a criação áreas protegidas, as leis de patrimônio genético e leis sobre uso de praguicidas e de ordenamento territorial

É, inquestionável a pressão causada pela pobreza das pessoas sobre os recursos naturais. Políticas públicas que minimizem a pobreza têm um papel fundamental na construção da agricultura sustentável. Mostra-se essencial melhorar o acesso às oportunidades e à educação, incorporar a população no manejo dos recursos e criar-se mais empregos (Trigo et al., 1994)

\subsection{Fatores decisórios para a sustentabilidade}

A agricultura processa-se através das decisões tomadas pelo agricultor que se baseiam principalmente no mercado (função de preço e demanda); também influem os fatores culturais, nível de informação, acesso a tecnologias e, pouco a pouco, cresce a preocupação do agricultor com a manutenção do potencial produtivo da área, que é, em geral, a sua visão de sustentabilidade.

Agricultores e pesquisadores estão continuamente lutando para desenvolver práticas de manejos de solo, culturas, animais e nutrientes que sejam produtivas, ambientalmente seguras, economicamente interessantes e socialmente aceitáveis (Karlen et al., 1995).

Em um trabalho desenvolvido com apoio da FAPESP, Sorrentino e Chaves (1998) avaliaram a visão de sustentabilidade por parte de agricultores familiares e a maior parte deles não conhece o termo e associa-o usualmente à expressão "sustento", referindo-se a capacidade do trabalho na lavoura de manter sua família com dignidade. 
Sustentabilidade é para a maioria a sobrevivência de sua família, sem que isso queira dizer agricultura de subsistência, em geral, sustentabilidade apesar de bastante associada à questão econômica é para os agricultores, sustento com melhoria da qualidade de vida. É também recorrente o conceito de não destruição dos recursos naturais.. Encontra-se, entretanto, no conjunto das entrevistas, associados ao termo agricultura sustentável, conceitos como viabilidade econômica, manutenção da produtividade, conservação de recursos naturais e culturais através das gerações, redução de insumos externos à propriedade, redução do uso de agrotóxicos, necessidade de tecnologias adaptadas, manutenção do homem no campo e garantia de educação.

As medições atuais de produtividade dos cultivos utilizam os rendimentos por área, sem levar em conta o efeito que a produção tem sobre a reserva dos recursos a serem utilizados (Trigo et al., 1994). Seria ingênuo considerar que a simples criação de indicadores diferentes dos econômicos motivaria agricultores e técnicos a pensar o processo agrícola de modo interdisciplinar.

A predominância do aspecto econômico no processo de decisão dos agricultores é resultado da forte pressão que estes vêm sofrendo pelo mercado (política de preços baixos para cesta básica, taxa de juros alta, alta de preços de insumos), e é claro, em virtude dos paradigmas da nossa sociedade de consumo.

O histórico dos insucessos da extensão rural no Brasil podem ser encontrados descritos em centenas de relatos e, principalmente no resultado que provocou na classe rural brasileira. Os técnicos em ciências agrárias são vistos com desconfiança, e projetos de extensão ou desenvolvimento rural são recebidos de maneira passiva, através da qual o agricultor fica aguardando pacotes tecnológicos ou presentes do governo.

A extensão rural brasileira baseou-se no convencimento dos agricultores na direção da modernização, ou melhor, da intensificação no uso de insumos modernos.

A partir da análise dos textos de Queda (1987) e Malagodi (1999) sobre o processo de interação entre técnicos e agricultores, pode-se depreender que os novos paradigmas da extensão são: a) A participação do agricultor deve existir, efetivamente, no diagnóstico, nas propostas, no planejamento, na implementação; b) A aprendizagem no processo de extensão ocorre em via de mão dupla, ou seja, agricultores e técnicos 
aprendem e ensinam; c) $\mathrm{O}$ técnico deve reconhecer o valor do conhecimento técnico local; d) Técnicos e agricultores buscam uma visão global da propriedade rural e e) Responsabilidade global deve permear a ação local.

O êxito das ações junto aos pequenos agricultores brasileiros depende do conhecimento das condições e do reconhecimento do papel do agricultor na determinação dos problemas e soluções.

Um dos aspectos que afeta negativamente as possibilidades da construção de um novo paradigma para a agricultura é a falta de diálogo entre técnicos, acadêmicos e agricultores. Há pouca eqüidade nessas relações, o que dificulta a inclusão de processos dialógicos, essenciais à sustentabilidade na agricultura.

As relações entre pesquisa e desenvolvimento são muito marcadas por um esquema racionalista que se caracteriza pela anterioridade das pesquisas em relação à difusão de técnicas; por uma hierarquia da ciência e pela especialização de tarefas, deixando à pesquisa o monopólio da inovação; pela linearidade das transferências técnicas, o que distancia cada vez mais os agricultores da reflexão, bem como da experimentação (Wünsch, 1995). Na prática, entretanto, a inovação tecnológica, no campo, ocorre por vias complexas e interativas, portanto, segundo Wünsch (1995), para que as medidas de pesquisa e desenvolvimento se tornem complementares é essencial a participação do agricultor.

O processo de adoção de novas práticas e/ou tecnologias por parte do agricultor depende de que este saiba, queira e possa adotar a inovação. (Galjart, 1972). O desenvolvimento participativo de tecnologias objetiva fortalecer a habilidade de experimentação dos agricultores, e incentivar a continuação do processo de inovação sob controle local (Reijntjes, 1994).

Assim, saber, depende de reconhecer que existe um problema a ser resolvido, ou algo a ser modificado. Querer depende de reconhecer-se que a proposta é confiável/desejável. Poder, depende da disponibilidade de recursos materiais, financeiros e humanos para implementar-se a inovação (Galjart, 1972).

A elaboração de indicadores e métodos que incluam outros parâmetros é apenas um primeiro passo para que se traga à realidade da agricultura seus aspectos ambientais 
e sociais. No nível do estabelecimento, no regional ou nacional, a agricultura de baixo investimento traz implícita a necessidade de monitorar de modo cuidadoso os fluxos de nutrientes, água e energia para que se possa alcançar equilíbrio com alta produção (Reijntjes, 1994).

\subsection{Aspectos da segurança alimentar}

A agricultura é um processo que tem por função primordial abastecer a sociedade com produtos imprescindíveis à manutenção das necessidades básicas da população. A sociedade demanda da agricultura o fornecimento destes produtos com menores custos e máximas qualidades possíveis, cresce também a preocupação com a segurança destes alimentos e os danos causados pelo processo agrícola.

Para Schumacher (1977) um dos erros mais graves de nossa era é a crença na solução do problema da produção.

Caso as taxas de crescimento populacional continuem com os atuais níveis indesejados, em 2100 a população mundial atingirá 10,2 bilhões de pessoas, ou entre 7,3 e 8,3 bilhões se for atingido um tamanho familiar médio próximo ao desejado. (Bongaarts, 1994).

As estimativas pessimistas consideram que o mundo poderá atingir uma população de 27,3 bilhões de pessoas em 100 anos, as previsões moderadas 10,2 bilhões e as otimistas 3,6 bilhões ( considerando-se inevitável que a população mundial, antes deste decréscimo atinja 8,6 bilhões nos próximos 50 anos) segundo Teich \& Nogueira (1999).

É inegável a conquista quanto à segurança alimentar na segunda metade do século XX. As evoluções tecnológicas introduzidas no sistema agrícola de produção a partir da Segunda Grande Guerra permitiu a elevação dos estoques e a redução da participação do custo de alimentação nos orçamentos das famílias.

Segundo Bird \& Ikerd (1994) a agricultura cumpriu seu objetivo público no século XX. As fábricas e escritórios foram supridos de trabalhadores e as despesas com alimentação diminuíram. Há um século, o censo de 1890 indicava que nos E.U.A., 22 
milhões de pessoas viviam em unidades agrícolas; passados cem anos essa fatia reduziuse para 4,6 milhões. A produção de alimentos absorvia cerca de $50 \%$ dos recursos do país, hoje o custo da alimentação onera menos de $12 \%$ da renda do consumidor médio americano. Entretanto, a sociedade agora parece estar impondo à agricultura um novo e mais amplo objetivo: desenvolver sistemas de produção de alimentos e fibras que sejam eficientes e produtivos, mas também seguros para o meio ambiente, viáveis em termos econômicos e proveitosos para a sociedade. As políticas governamentais do futuro têm de levar em consideração a qualidade de vida das pessoas que trabalham e moram nas comunidades rurais, bem como da sociedade como um todo, enquanto consumidores e ocupantes do ambiente natural.

Qualquer avaliação de desempenho da agricultura das nações mais avançadas, segundo Veiga (1994), durante a segunda metade do século XX será forçosamente levada a constatar que ela garantiu, às populações, um inédito grau de segurança alimentar. Foi somente nos últimos 30 ou 40 anos que amplos contingentes de desvalidos de alguns países da América do Norte, Europa e leste Asiático tiveram acesso a uma verdadeira abundância alimentar. Este processo ocorreu com tal intensidade que, hoje em dia, essas sociedades defrontam-se com os problemas de saúde causados por dietas pletóricas, enquanto o resto do mundo continua a viver com a degeneração causada pela fome. Simultaneamente, também tem sido nos países adiantados onde mais cresce a consciência sobre as distorções ambientais de seus sistemas de produção e do padrão de consumo de alimentos. Ampla gama de manifestações sociais permite perceber uma ascendente preocupação com a salubridade alimentar, que tende a estar cada vez mais ligada à conservação dos recursos naturais usados em sua produção. E as "pressões decorrentes já requerem novos métodos de produção agropecuária que venham a reduzir os impactos ambientais adversos e assegurar altos níveis de pureza e não toxicidade dos alimentos. É este, em última instância, o desafio social embutido na expressão "agricultura sustentável". Ainda segundo Veiga (1994), nesses países desenvolvidos, onde as políticas públicas já vêm reagindo à nova exigência social, começa a ficar clara a complexidade da transição a um novo padrão agroalimentar.

O processo está bem mais atrasado na América Latina, mas já entrou nas 
prioridades de instituições regionais, tornando perceptíveis alguns avanços, particularmente no âmbito da pesquisa agropecuária.

$\mathrm{O}$ rápido crescimento da população até o início do século XXI exigirá aumentos de produção que dificilmente poderão esperar pela superação do padrão tecnológico atual. Enquanto isso, a necessidade de obter segurança alimentar para a maioria dos povos continuará legitimando práticas produtivas que degradam recursos naturais, poluem o meio ambiente e contaminam os alimentos. Permanecerão assim as estratégias produtivas resultantes de estímulos econômicos de curto prazo, que não levam em conta a necessidade de proteger o patrimônio natural e assegurar o bem estar a longo prazo, que levaram os sistemas agricolas atuais a apresentarem uma série de distorções. Tornase cada vez mais evidente a dependência da agricultura de insumos energéticos como resposta à disseminação de espécies de importância econômica cada vez mais dependentes de nutrientes, como também a perda de produtividade dos solos como resultado dos processos de degradação e perda de fertilidade por má utilização agronômica (Trigo et al., 1994). Ao mesmo tempo, os processos de desertificação avançam de maneira significativa, particularmente nos ecossistemas de sequeiro, onde já se observam processos degradatórios em $70 \%$ da área total. Nos ecossistemas irrigados a utilização irracional dos sistemas de irrigação tem reduzido a produtividade como conseqüência de processos de sedimentação e crescentes problemas de salinização e alcalinização. Os riscos de desertificação no planeta afetam $43 \%$ das áreas da África, $32 \%$ da Ásia e 19\% da América Latina (FAO, 1984).

O presente trabalho discute a sustentabilidade na agricultura, entretanto, esta depende diretamente do que a sociedade está demandando dela. Não há dúvidas de que caso todos consumíssemos como a média americana de consumo o mundo dos humanos não sobreviveria. Temos atualmente uma realidade na qual diversos países caminham para fazer parte do clube da sociedade de consumo, como Índia, China e países do leste europeu. O padrão atingido por uma minoria de privilegiados é inevitavelmente o sonho que a maioria carente busca atingir; isto é inviável em virtude das limitações do próprio meio. O sonho que se busca, só pode ser atingido pelos poucos mais rápidos, fortes e criativos. Schumacher (1977) em seu livro "O Negócio é ser pequeno" fala sobre um 
novo sonho para a nossa espécie, sonho de simplicidade, de humildade e que todos poderiam atingir.

O último relatório sobre o Desenvolvimento Mundial (WDR) de 1999, considerou que o mundo está perdendo a guerra contra a miséria. Indicadores como consumo de calorias, qualidade das moradias e o acesso aos serviços básicos continuam a ser profundamente insatisfatórios. Uma em cada 5 crianças não completa 5 anos de escola e, uma porcentagem semelhante não consome a quantidade de proteína e calorias necessárias, dado este que explica a mortalidade anual de 9 milhões de crianças com menos de 5 anos nos países pobres (Sotero, 1999).

A FAO recomenda um mínimo de $3.000 \mathrm{kcal}$ per capita/dia para a manutenção nutricional. Entretanto, as pessoas não necessitam energia apenas para sua manutenção, utilizam-na também para suas atividade de lazer, preparo de alimentos, transporte, aquecimento, moradia e vestuário. Há no mundo uma enorme disparidade no uso da energia, sendo seu uso intensivo associado às pessoas com padrões de vida almejados pela maioria desfavorecida. Em média, o consumo diário per capita de energia é de aproximadamente $15.000 \mathrm{kcal}$. A média em países em desenvolvimento é de 6.300 $\mathrm{kcal} /$ dia, em países industrializados $52.800 \mathrm{kcal}$, chegando a um consumo de 230.000 $\mathrm{kcal} /$ dia pelo chamado homem tecnológico (Goldemberg, 1998). Segundo dados do Banco Mundial de 1980 , os países industrializados suportam $26 \%$ da população mundial, consomem $78 \%$ da produção e $81 \%$ da energia. Um americano consome, em média, tanta energia quanto 2 europeus, 55 indianos, 168 tansanianos e 900 nepalis. (Strahm, 1989).

Segundo dados da ONU (1990), o consumo de energia no mundo passou de 203 hexajoules para 310 no periodo entre 1970 e 1990, principalmente devido aos aumentos populacionais, e ao aumento do consumo per capita dos paises em desenvolvimento e nos do leste europeu. Estes dados podem ser melhor analisados no apêndice 7.

$\mathrm{O}$ custo energético total para satisfazer as necessidades humanas básicas varia entre 27.800 e $36.400 \mathrm{kcal} /$ dia per capita (Goldemberg, 1998). Segundo as Estatísticas da FAO de 1998, existem no mundo 20 países (16 na África, 3 na Ásia e o Haiti) com taxas per capita médias de fornecimento energético na dieta abaixo de $2000 \mathrm{kcal} / \mathrm{dia}$; 
estes países encontram-se nesta situação devido a conflitos armados ou sub-produção de alimentos. Pelo menos 29 países enfrentam algum problema de miséria associada à fome. A multidão de miseráveis, que era de 1,2 bilhão em 1987, já soma hoje 1,5 bilhão, ou $25 \%$ da população do planeta, e deve chegar perto de 2 bilhões no ano de 2015 (Sotero, 1999). Os diferentes cenários de consumo podem ser analisados em detalhe nos apêndices 5 e 6 .

O nível seguro de consumo de proteína, segundo as recomendações nutricionais da FAO, é de $37 \mathrm{~g}$ per capita por dia para uma pessoa adulta. Para Goldemberg (1998), o nível almejado de consumo de proteína dentro do Modelo de Desenvolvimento Mundial inspirado no modelo americano é de $\operatorname{lo0g}$ per capita/dia.

Para o atendimento às demandas da sociedade a agricultura dispõe de uma área limitada, conforme os últimos números da FAO (1998) a área total de terras no mundo é de 13.048.407.000 de hectares, destas áreas apenas 1. 381.917 hectares são considerados aráveis. Os dados da FAO (1998) podem ser analisados no Apêndice 4.

A área cultivada atualmente restringe-se a $0,31 \times 10^{9}$ ha (Serra et. al., 1979). Caso não se continue com os processos de expansão agrícola, que implicam em emissão de gases estufa e perda de biodiversidade é com a atual área cultivada que se deve contar para garantir o bem--estar da população mundial.

\subsection{Conceitos de energia}

Energia é a capacidade de realizar trabalho e é equivalente ao trabalho propriamente dito, é medida em unidades como Unidade Térmica Britânica (BTU), kilocaloria, Joule, kilowatt-hora. No apêndice 2 podem ser encontrados diversos fatores de conversão para as diferentes unidades.

Força é uma quantidade vetorial (uma quantidade tendo magnitude e direção) tendendo a produzir mudanças no movimento dos objetos, medida em unidades como kilogramaforça, dina e Newton. Trabalho é o produto da força por uma distância, medido por unidades como newton-metro. Potência é o tempo no qual um trabalho é realizado ou energia é dispendida, é medida por unidades como watt $\left(\mathrm{J}^{-\mathrm{s}^{-1}}\right)$ (Fluck \& 
Baird, 1982).

Os princípios que governam as conversões da energia são as duas leis da termodinâmica.

A Primeira Lei da Termodinâmica ou Princípio da Conservação da Energia, pode ser enunciada da seguinte maneira: Energia não pode ser criada ou destruída, mas pode apenas mudar de uma forma para outra. A energia total existente sob diversas formas é invariável.

A Segunda Lei da Termodinâmica ou Lei da Entropia, trata da irreversibilidade dos processos naturais, segundo Odum (1969) pode ser enunciada da seguinte maneira: nenhum processo que implique uma transformação da energia ocorrerá espontaneamente, a menos que haja uma degradação da energia de uma forma concentrada para uma dispersa.

A entropia é a medida da energia não-disponível que resulta das transformações, também pode ser considerada um índice geral da desordem de um sistema associado com a degradação da energia. A entropia do universo não para de crescer, tendendo a um máximo no qual encontremos um equilíbrio termodinâmico.

A segunda lei da termodinâmica nos remete à questão da qualidade da energia, pois as mesmas quantidades de energia de formas diferentes possuem diferentes potenciais para realizar trabalho. A energia química contida nos combustíveis fósseis possui um alto grau de ordenação, ou seja, uma grande disponibilidade de energia, maior que a mesma quantidade de energia oriunda da luz solar, que por sua vez está mais disponível que o calor disperso nas águas dos mares. Segundo Cavalcanti (1997), ao extrair recursos de baixa entropia, ordenados, deste último e jogar de volta lixo, resíduos de alta entropia, matéria em desordem, o processo econômico muda o perfil do meio no seu aspecto qualitativo. A teoria econômica neoclássica exclui a realidade física da produção, os recursos naturais e serviços ecológicos não fazem parte das funções de produção. Einstein considerava a segunda lei da termodinâmica a lei suprema da natureza e a lei fundamental da ciência. O aumento da entropia até seu limite é inevitável e um dia, inexoravelmente, o universo não terá quentes e frios, altos e baixos, o fim do mudo não é gelado ou quente, é morno. O problema da atual sociedade é 
depender de processos que geram grande entropia, da transformação de recursos de baixíssima entropia como combustíveis e energia elétrica para a obtenção de materiais e serviços altamente elaborados. A degradação da qualidade da energia em uma intensidade jamais vista pode ser avaliada pela quantidade de lixos, poluentes, barulho e poluição visual existente em nossas cidades.

Alguns estudiosos tentaram avaliar o dano, ou nível de degradação entrópica de diversas formas de energia utilizadas pelo homem. Odum \& Odum (1981) citados por Flück \& Baird (1982) organizaram a seguinte tabela com fatores de qualidade de energia:

Tabela 2: Fatores de qualidade de energia

\begin{tabular}{ccc}
\hline Tipo de Energia & $\begin{array}{l}\text { Calorias } \\
\text { Equivalentes } \\
\text { solares }\end{array}$ & $\begin{array}{c}\text { Calorias equivalentes de } \\
\text { Combustiveis Fósseis }\end{array}$ \\
\hline Luz Solar & 1,0 & 0,0005 \\
Produção Vegetal Bruta & 100 & 0,05 \\
Produção Vegetal Líquida (madeira) & 1.000 & 0,5 \\
Combustível Fóssil (entregue para uso) & 2.000 & 1,0 \\
Energia na água elevada & 6.000 & 3 \\
Eletricidade & 8.000 & 4 \\
\hline
\end{tabular}

Fonte: Odum \& Odum (1981)

Os organismos vivos, os ecossistemas assim como os agroecossistemas e os sistemas urbano - industriais são sistemas termodinâmicos abertos, fora do ponto de equilíbrio, que trocam continuamente energia e matéria com o ambiente para assim diminuir a entropia interna, mantendo a ordem necessária à manutenção da vida e do sistema (Odum, 1969). Na natureza, diversidade é sinônimo de estabilidade, a simplificação dos sistemas agrícolas implica no crescimento dos fatores que a desestabilizam obrigando os agricultores a recorrerem a técnicas mais intensivas, ou seja, de baixa entropia e alto valor energético, para preservar as condições básicas à manutenção da produtividade (Romeiro \& Salles Filho, 1997). Essas técnicas não resolvem os desequilíbrios são apenas medidas paliativas para garantir a produção. 
Portanto, podemos definir o comportamento da energia nos sistemas como um fluxo, visto que as transformações energéticas ocorrrem em um sentido único e não em ciclos como a matéria. Os organismos vivos e os ecossistemas mantêm-se através de seu consumo de entropia negativa (neguentropia) do meio ambiente. Estão distantes do equilíbrio termodinâmico e estabilizam-se pela constante dissipação de energia e matéria (Cavalcanti, 1997). Os ecossistema terrestres em seu conjunto podem ser sustentados por que representam somados um sistema fechado que pode ser mantido em níveis mínimos caso não seja perturbado além de sua capacidade de suporte (Cavalcanti, 1997). A homeostase própria dos sistemas naturais faz com que sua produção de entropia seja mínima. A eficiência ecológica de um sistema decresce na medida em que passa demandar matéria e energia de baixa entropia do meio ambiente para manter sua estabilidade. Este aumento da degradação entrópica ocorre e é inerente aos processos, principalmente nos mais tecnificados, independentemente de um possível aumento da produtividade que possa ocorrer.

\subsubsection{Demanda e disponibilidade de energia}

De acordo com o Relatório Bruntland da "World Comission on Environment and Development" de 1987, a demanda energética do mundo crescerá até $500 \%$ nos próximos 40 anos, com o crescimento populacional do terceiro mundo e a busca por atingir padrões de vida comparáveis àqueles do mundo desenvolvido, no qual um quinto da população consome mais de 50\% da energia comercial do globo (Gibbons et al., 1989 citados por Hall \& Hall, 1993). Um outro fator agravante é o crescimento da demanda energética dos processos de extração de recursos energéticos, em 1905, um barril de petróleo rendia 46 barris retirados; a relação atual é de menos de 6 barris obtidos por barril utilizado (Cavalcanti, 1997). Ou seja, o aprofundamento das reservas está diminuindo a relação custo - benefício da sua exploração. Este fato reduz a possibilidade de que a descoberta de novas reservas venha a diminuir a intensidade do problema de abastecimento energético. A tabela 3 expõe o cenário atual quanto à perspectiva de fornecimento de petróleo em função das reservas conhecidas e dos atuais 
níveis de consumo.

Tabela 3: Reservas de petróleo e tempo para depleção total

\begin{tabular}{|c|c|c|c|}
\hline \multirow[t]{3}{*}{ REGIÃO } & \multicolumn{2}{|c|}{$\begin{array}{l}\text { RESERVAS DE } \\
\text { PETRÓLEO }\end{array}$} & $\begin{array}{c}\text { RESERVAS RESTANTES } \\
\text { EM } 1989 \text { TAXAS DE } \\
\text { PRODUÇÃO }\end{array}$ \\
\hline & 1980 & 1990 & \multirow[b]{2}{*}{ NÚNERO DE ANOS } \\
\hline & \multicolumn{2}{|c|}{ BILHOัES DE BARRIS } & \\
\hline ORIENTE ME்DIO & 362 & 660 & 110 \\
\hline AMÉRICA LATINA & 70 & 125 & 51 \\
\hline RÚSSIA E LESTE EUROPEU & 66 & 60 & 13 \\
\hline ÁFRICA & 55 & 59 & 28 \\
\hline ÁSIA E OCEANIA & 40 & 47 & 20 \\
\hline AMÉRICA DO NORTE & 39 & 42 & 10 \\
\hline EUROPA OCIDENTAL & 23 & 18 & 13 \\
\hline MUNDO & 665 & 1.011 & 44 \\
\hline MUNDO (TEP) $10^{9}$ & & 138,5 & \\
\hline MUNDO (GCAL) $10^{9}$ & & 13,85 & \\
\hline
\end{tabular}

Fonte: "British Petroleum Statistical Review" citado por Flavin e Lenssen (1991).

A alta eficiência econômica de alguns países capitalistas é, em grande parte, um resultado do alto uso de combustíveis fósseis. Isto foi possível, especialmente nos E.U.A devido à abundância de petróleo e carvão da primeira metade do século (Hall \& Hall, 1993).

Aproximadamente $17 \%$ do total da energia utilizada na economia americana é consumida nos sistemas alimentares (Pimentel, 1984 citado por Pimentel et al., 1989). Cerca de $6 \%$ para produção, $6 \%$ para processamento e embalagem e o restante para distribuição e preparação. Estes $17 \%$ do total da energia representa 1.500 litros de combustível por pessoa/ano apenas para a alimentação. Foi calculado que se toda a população do mundo consumir como a americana as reservas de óleo do mundo durariam apenas mais 12 anos, isto usando todo o óleo apenas para produção, nada para transporte, aquecimento e resfriamento (Pimentel, 1984).

Desde a crise energética de 1973 o consumo americano de energia para a produção agricola continuou a crescer, ao mesmo tempo que a força de trabalho continuou a declinar. 
As usinas para produção de energia nuclear estão, desde 1998, em decréscimo de produção; todos os paises desenvolvidos cancelaram nos últimos anos a instalação de novas usinas e a maior parte deles tem um cronograma para desativação total das que estão em funcionamento; a razão para isto é o alto custo de produção da energia nuclear comparado a outros sistemas, a pressão de ecologistas e da sociedade por maior segurança e contra essas usinas e a dificuldade crescente em encontrar locais seguros para a deposição dos rejeitos atômicos.

O setor agropecuário consumia $8 \%$ da energia final consumida pelos diferentes setores da economia nos anos 70, atualmente este valor reduziu-se para 5\% (Januzzi, 1994).

A intensificação do uso da energia nos países em desenvolvimento vinha sendo um objetivo generalizado por acreditar-se que esta seria a saída para a melhoria da qualidade de vida nesses países. Apesar do aumento do consumo de energia chegar a 4 vezes o que era em 1960, os caminhos para este crescimento de consumo tem feito com que estes países aumentem seu endividamento externo, sofram com as crises de petróleo e piorem sua qualidade ambiental. Em geral a abordagem tradicional não visa a maximização dos serviços da energia mas o aumento dos suprimentos. (Lenssen, 1991). Os diversos cenários para o consumo energético mundial nos próximos 20-30 anos indicam, em geral, poucas mudanças na estrutura do abastecimento mundial. As perspectivas da substituição de recursos energéticos não-renováveis por recursos renováveis não são, em geral, promissoras, como podemos analisar nos apêndices 5 e 6 .

\subsubsection{Uso da energia na agricultura}

Segundo Cavalcanti (1997), os limites termodinâmicos indicam claramente o que pode ser feito. A construção de um desenvolvimento termodinamicamente responsável pode lançar as bases fundamentais para o desenho de uma sociedade sustentável.

Segundo Januzzi (1994) analisando dados do balanço energético nacional de 1992, o consumo de energia do setor agropecuário tem variado entre 5 e $8 \%$ da energia total consumida no país. Deste percentual, $48 \%$ representa consumo de óleo diesel, que 
se configura como o principal energético do setor; isto demonstra que a agricultura, em geral, não foge ao padrão mundial no qual formas não-renováveis de energia predominam sobre as demais.

Os organismos vivos e o seu ambiente não-vivo estão inseparavelmente interrelacionados e interagem entre si. Chamamos de sistema ecológico ou ecossistema qualquer unidade ( biossistema ) que abranja todos os organismos que funcionam em conjunto numa determinada área, interagindo de tal forma que um fluxo de energia produza estruturas bióticas claramente definidas e uma ciclagem de materiais entre as partes vivas e não-vivas (Odum, 1959).

Ecossistemas naturais funcionam com energia de modo auto-regulado, a energia solar é o único combustível para esses sistemas. (Fluck \& Baird, 1982).

Segundo Odum (1969) os agroecossistemas têm uma grande dependência energética para a produção e ainda as plantas e animais do sistema sofrem seleção artificial e não natural.

Há entretanto limites, cada vez mais próximos para a intensificação do uso da energia na agricultura, devido à escassez de recursos energéticos, aos limites biofísicos do ambiente, à degradação dos espaços e da qualidade dos produtos agrícolas. Não existem mais razões técnicas ou econômicas para ampliar-se o uso de fertilizantes pois após um determinado ponto a resposta à esta entrada inexiste ou é mesmo negativa, também não há possibilidade de se aumentar a mecanização agrícola uma vez que isto só implicaria em perdas fisicas e biológicas do solo.

Ecossistemas Naturais que dependem exclusivamente da luz solar como florestas de altitude e mares subsistem com um nível de energia anual entre $1.000-10.000$ $\mathrm{kcal} / \mathrm{m}^{2}$. Ecossistemas que dependem de luz solar e subsídios naturais, como estuários e algumas florestas úmidas, necessitam entre $10.000-40.000 \mathrm{kcal} / \mathrm{m}^{2}$ por ano. Ecossistemas que dependem de energia solar e subsídios antropogênicos (agricultura, aqüicultura) $10.000-40.000 \mathrm{kcal} / \mathrm{m}^{2}$ esistemas urbano - industriais (cidades, bairros industriais) 100.000 a $3.000 .000 \mathrm{kcal} / \mathrm{m}^{2}$ Odum (1969)

A constante solar é $1360 \mathrm{~W} / \mathrm{m}^{-2}$ ou $2 \mathrm{gcal} / \mathrm{cm}^{-2} / \mathrm{min}$. Um máximo de $67 \%$ pode atingir o solo, em um dia de verão, sem nuvens ao meio-dia, ou seja apenas 1,34 
$\mathrm{gcal} / \mathrm{cm}^{-2} / \mathrm{min}$. Dependendo da latitude, a energia solar que atinge a superficie, anualmente, está entre 1 e $2 \times 10^{6} \mathrm{kcal} . \mathrm{m}^{-2}\left(2739,7\right.$ e $5479,5 \mathrm{kcal} . \mathrm{m}^{-2}$.ou 27,4 e $54,8 \mathrm{x}$ $10^{6} \mathrm{kcal} . \mathrm{m}^{-2}$ por dia).

Antes da revolução industrial a agricultura dependia quase que exclusivamente de recursos gerados na própria propriedade; a primeira Revolução Agrícola que promoveu sistemas de rotação como o Norfolk na Inglaterra e a integração da produção vegetal à animal possibilitaram um grande aumento da eficiência da produção sem implicar no uso de fontes exógenas de nutrientes ou energia que nesta época, entre os séculos XVII e XIX, não se encontravam disponíveis (Romeiro \& Salles Filho, 1997).

A modernização da agricultura está vinculada a diversos fatores, dentre eles a intensificação de produtos obtidos com alto conteúdo energético. Desta maneira, o aumento de produtividade importa no incremento do dispêndio de energia (Mello, 1986).

O desenvolvimento tecnológico ocorrido na agricultura brasileira nos últimos trinta anos (1960-1990), e o conseqüente aumento da demanda de insumos energéticos no setor, traz à tona a questão da eficiência energética (Comitre, 1995). Segundo Fancelli (1994), o atual sistema de produção tende ao balanço energético negativo.

As modificações do processo agrícola das últimas três décadas ocorreram no sentido de induzir os agricultores a substituírem suas práticas tradicionais por outras com maior intensidade energética, com o intuito de promover a produtividade média. Os fracassos dos projetos de desenvolvimento agrícola, em geral, ocorrem por não atingirem os agricultores visados e por incentivarem um modelo tecnológico de alto custo econômico e energético (Wünsch, 1995).

Nos agroecossistemas existe energia entrando em diversas formas; está na forma da radiação solar que incide sobre as plantas na área cultivada, no trabalho realizado pelas pessoas, animais ou máquinas e ainda nos diferentes insumos e materiais que consumiram energia para sua obtenção (Mello, 1986). De acordo com Serra et al. (1979), embora se reconheça a influência de fatores básicos como o clima, solo e variedades, a produção agrícola é seguramente dependente da energia investida na cultura. O mesmo Serra et al. (1979), lembra que usando a tecnologia moderna, os Estados Unidos investem $15.522 \mathrm{Mcal} / \mathrm{ha}$ na cultura do arroz obtendo uma 
produtividade de 5,8t/ha enquanto que com a aplicação de tecnologia tradicional, as Filipinas investem $41 \mathrm{Mcal} / \mathrm{ha}$ obtendo produtividade de 1,25t/ha. Isto significa 378 vezes mais energia para uma produção apenas 4,6 vezes maior. Segundo Gorgatti (1984), uma medida expressiva do aumento de produtividade conseguido pela utilização de práticas modernas é dada pelo fato de que, enquanto na agricultura nômade um hectare produz alimento básico para uma pessoa e, na agricultura considerada tradicional a taxa se eleva para quatro a seis pessoas, na agricultura moderna a produção de cereais chega a alimentar 20 a 25 pessoas por hectare/ano. Se, por um lado, o desenvolvimento de novas técnicas gerou avanços na produtividade de determinadas culturas, por outro, atingiu um padrão de consumo energético de elevada dependência em relação a recursos dos quais o Brasil não possui auto-suficiência, caracterizando-se uma dupla dependência: tecnológica e econômica (Comitre, 1995).

Pimentel (1973), observou que a crise energética teria um impacto significativo na tecnologia de produção de alimentos nos EUA e na Revolução Verde porque ambos os sistemas de produção dependiam de altos investimentos energéticos. Investimentos de combustíveis fósseis tornaram-se de tal forma integrais e indispensáveis à moderna agricultura, que uma crise energética terá um impacto significativo na produção de alimentos em todas as partes do mundo que têm adotado ou estão adotando o sistema ocidental de produção.

Segundo Mello (1986), os gastos energéticos são proporcionais ao grau de interferência mecânica e química nos ecossistemas, sendo a tração motorizada e os insumos químicos para fertilização e defesa da produção as parcelas que representam os maiores custos energéticos.

Outro impacto significativo deste processo foi a redução da necessidade de mãode-obra na agricultura. Na agricultura americana, durante o período entre 1920 e 1973 , enquanto a eficiência no uso do trabalho humano aumentava ( em virtude do crescente uso de energia por hora de trabalho), a eficiência energética industrial diminuia por causa do decréscimo na quantidade de trabalho humano por unidade de energia (Hall et al., 1986 citados por Hall \& Hall, 1993). 


\subsubsection{Análise energética na agricultura}

Análise energética é a análise objetiva das quantidades fisicas de energia envolvidas em um processo ou sistema, ou seja, a identificação e mensuração dos fluxos de energia. (Fluck \& Baird, 1982).

Existem duas escolas principais de análise energética, aquela proposta pelo "International Federation of Institutes for Advanced Study" - IFIAS) que objetiva facilitar as conversões, previsões de demanda e efeitos, prevendo os efeitos de queda na oferta e compreendendo o sistema termodinâmico; e a escola de Odum, ou Ecoenergética que se constitui em um procedimento de avaliação energética que pode ser utilizado para identificar recursos alternativos de manejo. Segundo diversos autores a tendência é que surjam novas formas de abordagem que venham a contribuir para uma união das duas escolas. $\mathrm{O}$ presente trabalho não é feito com o intuito de se realizar uma síntese das escolas energéticas mas tenta incluir aspectos de ambas, a mensuração do valor incorporado a bens e serviços e a análise conjunta de outros aspectos associados à sustentabilidade de sistemas.

Existe energia entrando nos sistemas agrícolas, tanto direta quanto indiretamente e os bens e serviços são em geral formados pelas duas formas de energia. Energia direta é aquela contida na comida para humanos e animais e também a do combustível para as máquinas. A energia contida em um bem ou serviço é a soma de esforço humano, combustível fóssil e outras formas de energia; a esta soma damos o nome de energia incorporada.

Diversos métodos são utilizados para determinar a quantidade de energia contida em um bem ou em um serviço, dentre os quais destacam-se:

1)Análise estatística: Determina a energia contida através de dados estatísticos. Divide-se a quantidade de energia consumida pelo país pelo seu produto nacional bruto, por exemplo, obtendo-se a intensidade energética da moeda. Exemplo: $11.917 \mathrm{kcal} /$ dollar em 1975 nos E.U.A. Através dos dados da Matriz energética: determina-se o valor energético de um bem ou serviço através da conversão segundo o consumo energético e o PIB do país, obtém-se o dado da intensidade energética da 
economia como um todo. Para o Brasil, segundo determinado em 1982, o valor é de $10.141 \mathrm{kcal} / \mathrm{US} \$$.

2)Análise de investimentos/produtos: Uma matriz quadrática de uma economia é formada considerando-se as quantidades de energia e produto por commodity.

3)Análise de processo: Identifica-se as redes e processos para se obter um determinado produto; essas redes e processos são analisados para determinar os investimentoss energéticos que somados traduzem a energia total necessária para geração do bem em questão. (Fluck \& Baird, 1982). Identificando os bens e serviços envolvidos no processo de geração e avaliando o custo energético total envolvido na criação de determinada quantidade do insumo podemos, assim, estimar seu valor energético.

Segundo Santos (1994), o índice usado para comparar as eficiências energéticas dos sistemas corresponde ao quociente do rendimento de grãos de cada espécie em estudo pela energia cultural, representada pelo uso de insumos e pelas atividades de operações realizadas no sistema. Esse índice é denominado de produtividade cultural. $\mathrm{O}$ resultado pode ser dado em $\mathrm{kg} / \mathrm{cal}$. Energia cultural é a energia gasta na obtenção de um bem ou serviço.

No caso de culturas destinadas à alimentação humana, investigações conduzidas nos EUA mostram que, para alguns alimentos, a razão entre a energia alimentar e a energia investida na cultura é menor que a unidade.

Entretanto como se trata de alimentos, mesmo que as razões sejam inferiores à unidade, ainda assim os teríamos que produzir porque constituem a única forma de energia que é aceita pelo organismo humano. Todavia, deve-se almejar sistemas de produção eficientes e racionais, fundamentados em uma atividade energeticamente sustentável, buscando-se o máximo rendimento econômico (Santos, 1994).

Segundo Santos (1994), a análise energética aliada à econômica pode contribuir para a compreensão dos rendimentos culturais obtidos nos diferentes sistemas de produção. Desta maneira, quando uma espécie não responde adequadamente aos seus investimentos energéticos, pode-se considerar que algum insumo está sendo 
desperdiçado e que poderia ser melhor aproveitado, principalmente, em países onde existe carência de produtos agrícolas.

Uma análise econômica permite conhecer os fluxos e taxas de retomo do capital investido, em um horizonte de tempo pequeno, sujeito à instabilidade de mercado e do sistema financeiro, e restrita ainda no espaço. Por outro lado, quando são avaliados os fluxos de energia que constituem o sistema, acrescenta-se um referencial que não está sujeito a mudanças no mercado e suas lógicas financeiras, não é limitado no espaço ou no tempo mas, antes, se submete às leis da natureza (Mello,1986).

Segundo Serra et al. (1979), a maior dificuldade para obtenção do indicador energético de uma dada cultura (isto é, a grandeza que mede a quantidade de energia investida no preparo do produto agrícola) é a computação cuidadosa da energia indireta embutida nas máquinas e nos produtos químicos utilizados como insumo para a lavoura. Evidentemente, qualquer produto ao ser elaborado exige o consumo de uma certa quantidade de trabalho humano, de transporte, de capital, de matéria prima e de combustível. Este combustível é chamado de energia direta. $\mathrm{Na}$ prática, esta energia representa apenas uma fração da quantidade total da energia realmente gasta; a diferença entre a energia direta e a total é definida como energia indireta. Nestas condições é extremamente importante contabilizar todas as energias indiretas para que se possa, no final, obter um número realista que exprima a energia total gasta como insumo dos produtos agrícolas.

Todavia, o primeiro ponto que se faz necessário estudar, quando se pensa em economia, é o da produtividade. Como diminuir racionalmente o uso de energia na agricultura, ou usar fontes alternativas, sem afetar negativamente a produtividade, se possível aumentando-a, é uma questão que deve ser respondida em qualquer estudo neste mister. Dentro das alternativas para se economizar energia no processo agrícola, não há dúvida de que o preparo do solo ou o sistema de cultivo ocupa um lugar de destaque. A questão é se descobrir, para cada situação edafoclimática, a intensidade ideal de movimentação do solo, além da qual o consumo de energia não se traduz em produtividade, isto é, o ponto de eficiência energética máxima. Outra variável importante, ressalta Vieira (1984), a ser vista no processo são as economias 
proporcionadas indiretamente a longo prazo. Se considerarmos a erosão como uma apreciável fonte de perda de energia no processo agrícola, poder-se-á concluir que sistemas agrícolas eficientes no controle da erosão, poderão ser poupadores de energia a longo prazo mesmo não o sendo a curto prazo.

Mello (1986), dentre as recomendações finais de seu trabalho, ressalta a necessidade da análise energética de diversos sistemas produtivos interagindo, pois, conhecendo-se os fluxos energéticos dos sistemas e suas interações pode-se aperfeiçoar o rendimento energético do conjunto.

O uso de insumos internos, por sua vez, não garante por si só a sustentabilidade do sistema de produção; sistemas agrícolas com baixo "investimentos" muitas vezes baseiam-se no uso de recursos sub-valorizados de modo não sustentável (Chambers et al., 1989).

\subsubsection{Análise dos Investimentos Energéticos}

\section{a. Sementes}

Pimentel, em seus trabalhos utlizou, diversas maneiras de valoração energética da semente; a principal forma considerou o dólar americano (US\$) como fator de conversão e o valor utilizado foi de $15.800 \mathrm{kcal} /$ US\$.

Para alguns autores a produção de mudas e sementes requerem maiores cuidados, portanto consomem mais energia; assim sendo utilizam dados energéticos dos sistemas de produção que apresentam maiores consumos de energia como os que representam a produção de sementes, como Serra et al. (1979), estes acrescem ao valor da semente, ainda, uma quantidade de energia equivalente ao seu transporte por $20 \mathrm{~km}$.

A FAO considera um valor, genérico, de $7170 \mathrm{kcal} / \mathrm{kg}$ para países industrializados e um outro valor, também genérico, de $3580 \mathrm{kcal} / \mathrm{kg}$ para países subdesenvolvidos.

Alguns autores, dentre eles Pimentel (1980), consideram o valor energético da semente como sendo igual ao do grão, outros como sendo o dobro do valor do grão.

Vários autores recomendam a conversão do custo financeiro em custo calórico. 
Esta recomendação foi seguida por Mello (1986) em seus trabalhos. Considerou o valor de $10.141 \mathrm{kcal} /$ dolar obtido através da divisão do consumo de energia primária pelo PIB; dados de 1982 da Matriz Energética Brasileira.

\section{b. Nitrogênio}

$\mathrm{O}$ nitrogênio fertilizante é obtido industrialmente pela liquefação do $\mathrm{N}$ atmosférico; para este processo são necessárias pressões de até 600 atmosferas e temperaturas de $600{ }^{\circ} \mathrm{C}$ (Malavolta, 1981). O processo de síntese da amônia, matériaprima básica na fabricação dos fertilizantes é descrito pela equação I:

$$
\mathrm{N}_{2}+3 \mathrm{H}_{2} \leftrightarrow 2 \mathrm{NH}_{3}+24.000 \mathrm{cal}
$$

Pimentel (1980) considerou $12.000 \mathrm{kcal} / \mathrm{kg}$ de N, Serra et al. (1979) 13.875 $\mathrm{kcal} / \mathrm{kg}$ de N e Mello (1986) $14.977 \mathrm{kcal} / \mathrm{kg}$ de N. Os dados variam de 12.000 a 25.000 $\mathrm{kcal} / \mathrm{kg}$, esta variação é função do tipo de matéria prima utilizada e do produto obtido (tipo de adubo nitrogenado), gás natural é a matéria prima que propicia o nitrogênio com menor custo energético. Dentre os produtos o de menor custo é a amônia anidra, seguida da uréia e do nitrato de amônio (Lockeretz, 1977).

Pela análise das fábricas brasileiras de fertilizantes nitrogenados, Felipe Júnior et al. (1984) encontraram um valor médio de $14.930 \mathrm{kcal} / \mathrm{kg}$ de $\mathrm{N}$. Mello (1986) considerou $6.917 \mathrm{kcal}$ por $\mathrm{kg}$ de uréia $(45 \% \mathrm{de} \mathrm{N})$.

Fluck \& Baird (1982) citam valores entre 33 e $68 \mathrm{MJ} / \mathrm{kg}(7887$ e $16252 \mathrm{kcal} / \mathrm{kg})$ para a amônia, 50 e $78 \mathrm{MJ} / \mathrm{kg}$ ( 11950,3 e 18642,4 kcal/kg) para a uréia, entre 59 e 77 $\mathrm{MJ} / \mathrm{kg}$ ( 14101 e $18403 \mathrm{kcal} / \mathrm{kg}$ ) para o nitrato de amônia. A média das indústrias para o nitrato de amônia é de $71.1 \mathrm{MJ} / \mathrm{kg}(16993,3 \mathrm{kcal} / \mathrm{kg}$ ). Valores entre 70 e $80 \mathrm{MJ} / \mathrm{kg}$ ( 16730,4 e 19120,5 kcal/kg) são os mais comuns citados por Fluck e Baird (1982) citando diversos autores.

\section{c. Fósforo}

O ácido fosfórico, matéria-prima para a maior parte dos adubos fosfatados, pode 
ser obtido por via úmida ou por via seca, a segunda exige que o concentrado fosfático seja fundido a mais de $1.300^{\circ} \mathrm{C}$. Consome, portanto, mais energia que a via úmida que utiliza apenas água e ácido sulfúrico para solubilizar o fósforo da rocha (Malavolta, 1981).

Os gastos de energia na produção de fertilizantes fosfastados estão na mineração, solubilização (temperaturas altas ou com ácido sulfúrico), transporte e embalagem. Termofosfato e Fosfato Rhenania exigem elevação de temperatura acima dos $1000{ }^{\circ} \mathrm{C}$.

Pimentel (1980) considerou $3.000 \mathrm{kcal} / \mathrm{kg}$ de $\mathrm{P}_{2} \mathrm{O}_{5}$, Serra et al.(1979) 1.665 $\mathrm{kcal} / \mathrm{kg}$ de $\mathrm{P}_{2} \mathrm{O}_{5}$ e Mello (1986) considerou $3.384 \mathrm{kcal} / \mathrm{kg}$ de $\mathrm{P}$ e $2.340 \mathrm{kcal} / \mathrm{kg}$ para Superfosfato Simples $\left(21 \%\right.$ de $\left.\mathrm{P}_{2} \mathrm{O}_{5}\right)$. Fluck \& Baird (1982) citam valores entre 9.7 e $22.1 \mathrm{MJ} / \mathrm{kg}(2318$ e $5282 \mathrm{kcal} / \mathrm{kg}$ ) para o superfosfato triplo. Encontraram também em seu levantamento o valor de $17.4 \mathrm{MJ} / \mathrm{kg}(4159 \mathrm{kcal} / \mathrm{kg})$ para o superfosfato simples.

\section{d. Potássio}

O processo de fabricação de adubos fosfatados necessita da realização de atividades como mineração, trituração, dissolução em água ou ácido sulfúrico, cristalização, filtração, secagem e transporte/embalagem (Malavolta, 1981). Em todas essas fases encontram-se gastos de energia.

Pimentel (1980) considerou $1.600 \mathrm{kcal} / \mathrm{kg}$ de K2O, Serra et al. (1979) 1.110 $\mathrm{kcal} / \mathrm{kg}$ de $\mathrm{K}_{2} \mathrm{O}$ e Mello (1986) $2.268 \mathrm{kcal} / \mathrm{kg}$ de $\mathrm{K}$. Mello (1986) considerou 1.718 $\mathrm{kcal} / \mathrm{kg}$ de Cloreto de Potássio ( $45 \%$ de N).

Outro valor encontrado na literatura é de $2.268 \mathrm{kcal} / \mathrm{kg}\left(60 \% \mathrm{~K}_{2} \mathrm{O}\right)$ para o cloreto de potássio. Fluck \& Baird (1982) citam valores de $\mathrm{K}_{2} \mathrm{O}$ de até $2.200 \mathrm{kcal} / \mathrm{kg}$

\section{e. Cálcio e Magnésio}

A produção de calcário envolve as seguintes etapas: perfuração, detonação, remoção, britagem, moagem, peneiramento e armazenamento (Malavolta, 1981). É claramente um material com menores custos energéticos envolvidos em sua produção, que os fertilizantes em geral.

Pimentel (1980) considerou $315 \mathrm{kcal} / \mathrm{kg}$ de calcário e Mello (1986) $400 \mathrm{kcal} / \mathrm{kg}$ 
de calcário. Usualmente cálcio e magnésio são fornecidos em quantidades mais que suficientes através da calagem, cujo objetivo é a correção química dos solos.

\section{f. Defensivos Agrícolas}

Defensivos requerem energia fóssil em grande quantidade para sua produção.

A energia é necessária diretamente pelo gasto de calor e eletricidade para síntese do ingrediente ativo e indiretamente dos combustíveis que geram os estoques de hidrocarbonetos usados na manufatura.

$\mathrm{Na}$ matriz americana para Agentes Químicos encontra-se um valor de 45.464 $\mathrm{kcal} /$ US\$, pelo menos quatro vezes acima do valor encontrado na matriz energética brasileira (1982).

Serra et al. (1979) consideram um valor médio de $73.260 \mathrm{kcal} / \mathrm{kg}$ para todos os defensivos, independentemente do tipo ou da formulação, que só inclui a energia para fabricação. Segundo Mello (1986), formicidas demandam $46.270 \mathrm{kcal} / \mathrm{kg}$ para sua fabricação enquanto herbicidas e inseticidas $74.250 \mathrm{kcal} / \mathrm{kg}$.

Além das variações com a energia dispendida com o ingrediente ativo, os dados também variam com a formulação, embalagem e transporte.

Tabela 4: Custo energético do fabrico de defensivos

\begin{tabular}{lcccc}
\hline & $\begin{array}{c}\text { Óleo } \\
\text { Emulsionável }\end{array}$ & Pó molhável & Grânulos & Pó seco \\
\cline { 2 - 5 } Herbicida & \multicolumn{5}{c}{ kcal/kg em função do tipo } \\
Inseticida & 99.910 & 62.770 & 86.600 & $-\cdots$ \\
Fungicida & 86.910 & 61.470 & 74.300 & 74.300 \\
& 64.910 & 27.770 & 51.600 & 51.600 \\
Formulação & \multicolumn{5}{c}{$\mathrm{kcal} / \mathrm{kg}$ em função da etapa de produção } \\
Embalagem & 33.300 & 2.500 & 3.600 & 3.600 \\
Transporte & 8.500 & 2.600 & 20.000 & 20.000 \\
\hline
\end{tabular}

Fonte: Pimentel (1980)

Segundo Pimentel (1980), os princípios ativos representam, em geral, a maior parte do valor energético dos defensivos. Em média os princípios ativos demandam, para sua fabricação, para herbicidas, $57.000 \mathrm{kcal} / \mathrm{kg}$, para fungicidas, $44.000 \mathrm{kcal} / \mathrm{kg}$ e 
inseticidas, $22.000 \mathrm{kcal} / \mathrm{kg}$

Entretanto, os valores médios podem ocultar diferenças significativas nos custos energéticos de princípios ativos, como podemos observar no apêndice 9. Princípio ativos de herbicidas bastante utilizados como Atrazina e Glifosate exigem investimentos energéticos bastante diferentes, 45 e $109 \mathrm{kcal} / \mathrm{g}$ respectivamente.

\section{g. Trabalho Humano}

Pimentel, em muitos de seus trabalhos considera, valor energético zero para o trabalho humano, por considerar que praticamente não há dispêndio extra de energia para o mesmo. Em alguns casos, o autor considerou um valor de $485 \mathrm{kcal} / \mathrm{h}$ de trabalho.

Pimentel (1974) e Cook (1976) determinaram diferentes valores para diferentes níveis de esforço, esforços leves demandam em média $300 \mathrm{kcal} / \mathrm{kg}$ em atividades leves, 400 em atividades moderadas, 500 em atividades pesadas, 600 em atividades muito pesadas, 50 durante o sono e 100 em outras atividades. Uma maior diversidade de valores energéticos para diferentes atividades humanas podem ser encontrados no apêndice 8. Em muitos trabalhos encontra-se o valor de $500 \mathrm{kcal} / \mathrm{hora}$ (Mello, 1986) .

O grupo de pesquisadores do "Institute for Energy Analyses of Oak Ridge" sugere que a energia gasta na forma de mão-de-obra não deva ser computada para fins de avaliação do índice de energia de um produto pois uma pessoa trabalhando ou desempregada requer praticamente a mesma quantidade de energia na forma de alimento, moradia, vestuário.

No relatório para a Secretaria de Tecnologia Industrial e Min. da Indústria e Comércio, Serra et al., (1979) consideram um valor pequeno; entretanto, afirmam que algum valor deve ser atribuído, no caso do Brasil, em função do trabalho braçal substituir as máquinas; em muitos casos consideram em seus trabalhos o valor recomendado por Heichel de $525 \mathrm{kcal} / \mathrm{h}$. Para perceber-se a distância entre os critérios, e conseqüentemente entre os valores atribuídos à intensidade energética do trabalho humano temos vários autores citados por Flück \& Baird (1982):

Entre 0,49 e 0,58 MJ/dia (117 e 138,6 kcal/dia) para a energia líquida muscular gasta no trabalho (Makhijani, 1975). Em casos no qual o trabalho é predominantemente 
intelectual este dado se torna pouco útil. Valores maiores são sugeridos por Revelle (1976) entre 6,4 e $8 \mathrm{MJ} / \mathrm{dia}(1529,7$ e $1912 \mathrm{kcal} / \mathrm{dia}$ ou $250 \mathrm{kcal} / \mathrm{hora})$, pois considera um porção da energia contida nos alimentos consumidos, teoricamente equivalente à porção gasta durante o trabalho. Este valor é igual ao determinado pela FAO.

Pimentel et al.(1973) e Stanhill (1974) recomendam valores entre 8 e 18,2 MJ/dia (1,91 e 4,35 Mcal/dia) equivalentes à energia total contida no alimento consumido.

Todos esses métodos apresentados buscam quantificar a energia consumida para o trabalho, outros se prestam para a avaliação dos recursos energéticos consumidos, como os utilizados por Willians et al. (1977) citados por Flück \& Baird (1982) que consideram valores entre 414,6 e 607,8 MJ/dia (99,1 e 145,3 Mcal/dia) para a manutenção da família rural americana e De Wit (1975) também citado por Flück \& Baird (1982) que calcula um valor chamado razão de substituição marginal de 543 MJ/dia (129,8 Mcal/dia). Este valor representa a taxa na qual a energia é substituída por trabalho, ou seja, quando um sistema de produção de uso intensivo de energia é substituído por outro menos intensivo.

\section{h. Trabalho Animal}

Um único animal de tração aumenta 10 vezes a potência de trabalho de um homem. Mello (1986) considerou $2.400 \mathrm{kcal} / \mathrm{hora}$, valor este que foi determinado por Odum. Encontram-se, entretanto valores entre 2000 (Pimentel, 1974) e $4600 \mathrm{kcal} / \mathrm{hora}$ (FAO, 1994). O apêndice 12 exprime o tempo médio para a realização de diversas operações agrícolas sob diferentes sistemas:

\section{i. Operações com Máquinas}

Pimentel (1980) soma a energia "contida" nos materiais que constituem cada máquina e implemento, incluindo pneus, a energia para fabricação, adiciona o valor de peças de reposição e ajusta o valor total conforme o custo acumulado para reparos (TAR). Este dado total é dividido pela expectativa de vida útil da máquina e do implemento e também pela área média trabalhada por ano. Em seus trabalhos o valor considerado é de $18.000 \mathrm{kcal} / \mathrm{kg}$. Encontram-se na literatura valores acima de 20.000 
$\mathrm{kcal} / \mathrm{kg}$. Os dados em geral variam de $10 \mathrm{a} 60 \mathrm{~kg}$ gastos por hectare trabalhado. Um dado médio para operações mecânicas é de $49.944 \mathrm{kcal} / \mathrm{hora}$ trabalhada. Em média a vida útil de um trator é considerada de 12 anos, a de um implemento, 15 anos. O combustível é considerado separadamente e é computado como energia direta da operação.

No apêndice 11 pode-se encontrar o referencial para estimar-se a energia direta, consumo de combustíveis, de diversos tipos de operações mecânicas. Os dados do apêndice 12 exprimem o tempo médio para a realização de diversas operações agrícolas sob diferentes sistemas, fundamental para estimarmos o desgaste das máquinas (energia indireta).

Pimentel (1980) calculou diversos dados que permitem o cálculo da energia dispendida por operação em função da depreciação por hora trabalhada para diferentes operações. Estes dados, encontrados no apêndice 13 fundamentam o cálculo para a energia indireta de operações mecânicas. Mello (1986) compilou os dados de forma simples, apresentando valores genéricos para as operações por hectare trabalhado. Um trator, segundo Mello, consome em média, $49.944 \mathrm{kcal} / \mathrm{hora}$. Um implemento de pulverização, $2.356 \mathrm{kcal} / \mathrm{hora}$. $\mathrm{O}$ resultado segundo seu critério seria a soma destas duas quantidades multiplicado pelo tempo médio necessário a cada operação. A tabelas 5 apresenta dados relativos à energia direta e indireta que compõem o valor energético de operações agrícolas compilados por Mello (1986).

Tabela 5: Custo energético para diversas operações

\begin{tabular}{lc}
\hline Operação & $\mathrm{kcal} / \mathrm{ha}$ \\
\hline Manutenção de Terraço & 27.567 \\
Escarificação & 77.188 \\
Aração & 110.268 \\
Gradagem & 49.621 \\
Pulverização & 42.300 \\
Semear/adubar & 45.550 \\
Colheita mecânica & 168.463 \\
\hline
\end{tabular}
Fonte: Mello (1986)

Serra et al. (1979) baseiam-se nos dados da Matriz Insumo-Produto, para 
determinar o custo energético de máquinas e implementos, consideram o valor da matriz Americana de 1967, ou seja, $19.955 \mathrm{kcal} / \mathrm{US} \$$.

\section{j. Transporte}

O transporte marítimo consome $120 \mathrm{kcal} / \mathrm{kg}$ para longas distâncias (Leach, 1975), o transporte rodoviário, 0,83 kcal/kg em $1 \mathrm{~km}$ (Pimentel, 1980).

Valores entre 88 e $129 \mathrm{kcal} / \mathrm{kg}$ transportado são encontrados para a energia direta demandada por diferentes meios de transporte segundo Hirst (1973) citado por Fluck \& Baird (1982) que calcularam a energia direta e indireta para transporte aéreo $(30,3 \mathrm{MJ} / \mathrm{t} . \mathrm{km})$, rodoviário $(4,34 \mathrm{MJ} / \mathrm{t} . \mathrm{km})$, ferroviário e hidroviário $(0,84 \mathrm{MJ} / \mathrm{t} . \mathrm{km})$. Os dados de Hirst (1973) podem ser encontrados na apêndice 14.

\section{Irrigação}

Pimentel (1980) considera na análise da irrigação o custo energético para manufatura dos produtos utilizados, o combustível utilizado para a bomba e sua eficiência, a elevação necessária da água, o tipo de irrigação. Em seu trabalho encontramos dados entre 5000 e $20000 \mathrm{kcal} / \mathrm{cm} \cdot \mathrm{ha}^{-1}\left(\mathrm{~cm} \cdot \mathrm{ha}^{-1}\right.$ equivale a $\left.100 \mathrm{~m}^{3}\right)$. Em diversos trabalhos de análise energética, Pimentel (1980) utiliza dados em média com $125 \mathrm{kcal} / \mathrm{m}^{3}$.

Segundo Mello (1986) os gastos energéticos envolvidos em irrigação são significantes e devem ser considerados, mesmo se forem apenas regos, canais ou bombas a baixas taxas de trabalho.

Para sistemas de aspersão, a FAO considera que o custo energético da irrigação chega a $2.145 .570 \mathrm{kcal} / \mathrm{ha}$ irrigado.ano, incluindo-se a depreciação do sistema e um gasto próximo a 180 litros de diesel/ano com o sistema.

Nos apêndices 18, 19 e 20 podem ser encontrados dados referentes à energia direta e indireta de irrigação para diferentes recalques e diferentes sistemas de irrigação, que fundamentaram os valores genéricos sugeridos pelo método. 


\section{m. Terra}

Tradicionalmente, a energia solar, tem sido considerada um bem grátis. Entretanto, o fazendeiro precisa possuir ou alugar terra para suportar as plantas que capturam a luz solar e o aumento do preço da terra reflete diretamente no aumento do valor da energia fotossintéticamente ativa. A terra é uma rede de captação não só para energia solar mas também para agroquímicos, $\mathrm{CO}_{2}$ e chuva. Valores entre 2.000 e

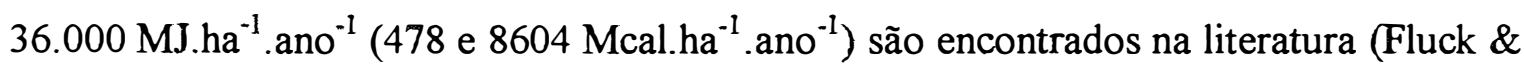
Baird, 1982).

Em geral, as análises energéticas não consideram qualquer valor para a terra, exceto aquelas nas quais o autor gera o índice de produtividade ecológica que se baseia no rendimento calórico da área em função da radiação solar.

\section{n. Insumos Orgânicos}

O valor energético de insumos orgânicos é calculado, em geral, segundo seu valor calórico. Em seus estudos comparativos entre sistemas orgânicos e convencionais de produção, Pimentel et al. (1984) consideraram $15.000 \mathrm{kcal} /$ tonelada de esterco de gado úmido. Nestes estudo observaram que a substituição do nitrogênio químico pelo esterco permitiu um decréscimo significativo no investimentos, sendo um dos fatores que contribuíram para que o balanço energético melhorasse de 4,47 para 7,34 do sistema convencional para o orgânico.

\section{Edificações}

Pimentel (1980) considera valores entre $38.000 \mathrm{kcal} / \mathrm{ft}^{2}$, para construções de serviços e $139.000 \mathrm{kcal} / \mathrm{ft}^{2}$ para residências.

\section{p. Outros Insumos}

Cook (1976) e Flück \& Baird (1982) compilaram valores para diversas matérias primas e substâncias, incluindo gasto na extração e processamento desses materiais; esses dados podem ser encontrados nas apêndice 15 e 16. Estes dados podem ser úteis para cálculo de fatores de conversão energéticos. 


\section{q. Combustiveis e Fontes de energia direta}

Pimentel (1980) calcula o valor de combustíveis segundo a soma de seu valor calórico à demanda energética para a produção (refino). Gasolina possui um valor de $8.179 \mathrm{kcal} / \mathrm{l}$ que acrescido de $1.930 \mathrm{kcal} /$ referente aos investimentos durante o processamento resulta em $10.109 \mathrm{kcal} / \mathrm{l}$. Diesel possui um valor calórico de $9.235 \mathrm{kcal} / \mathrm{l} \mathrm{a}$ este deve ser adicionado um valor de $2.179 \mathrm{kcal} / \mathrm{l}$ referente aos investimentos durante o processamento resulta em $11.414 \mathrm{kcal} / \mathrm{l}$ (Pimentel, 1980).

Os valores para gasolina variam entre 9.449 e 11.110 , do diesel entre 10.358 e 11.414, para eletricidade pode ser utilizado um valor de $2.863 \mathrm{kcal} / \mathrm{kwh}$ (Cook, 1976; Serra, 1979; Pimentel, 1980 e Mello, 1986). Os valores podem ser analisados no apêndice 10 .

\subsubsection{Análise dos Produtos}

A utilidade de materiais vegetais para humanos e animais depende de sua composição e da energia armazenada nas ligações químicas de sua constituição orgânica (Marten, 1988). A energia armazenada no material vegetal é determinada pelo conteído de calor determinado em bomba calorimétrica.

Os produtos gerados são avaliados para análises energéticas segundo o seu valor calórico; para este trabalho, interessa-nos também conhecer seu valor protéico.

Pode-se valorar energeticamente os produtos agrícolas simplesmente considerando o valor calórico. A utilidade dos produtos de origem vegetal, tanto para as pessoas quanto para os animais depende de sua composição e da energia armazenada nas ligações químicas da sua constituição orgânica (Loomis \& Connor, 1996). A energia

armazenada nos materiais vegetais é determinada pelo conteúdo bruto de calor, que por sua vez é auferida através de bombas calorimétricas.

Outras questões referem-se à qualidade do produto e seu valor entre os diversos grupos bioquímicos.

O cálculo da energia gerada pelos produtos de cada sistema deverá ser obtido 
com a conversão das quantidades produzidas em função do valor calórico. Ou seja, o produto obtido no processo agrícola, aquele que é extraído do sistema, deve ser multiplicado em função da quantidade ou massa gerada, pelo fator de conversão (valor calórico). Os teores de proteína também são apresentados pois, no método proposto contribuem para a formação do índice de segurança alimentar do sistema. Esses dados podem ser encontrados na apêndice 17.

\subsubsection{Apresentação dos Resultados ou Índices Energéticos}

Os resultados dos trabalhos de análise energética variam, inclusive, a forma de apresentação de resultados.

a) PRODUtOS/INVESTIMENTOS: kcal obtidas divididas pelas calorias consumidas no processo produtivo (Pimentel, 1980)

b) PRODUTIVIDADE CULTURAL: $\mathrm{kg}$ de produto obtido dividido pelas calorias consumidas no processo produtivo (Santos, 1989).

c) PROTEÍNA/INVESTIMENTOS: $\mathrm{kg}$ de proteína obtidas por hectare divididas pelas calorias consumidas (Pimentel, 1980).

d) PROdUTIVIdAde ECOlÓGICA: Quantidade de energia obtida por hectare dividida pela quantidade de energia fornecida pela radiação solar durante o período de ocupação da cultura. 


\section{MATERIAL E MÉTODOS}

\subsection{Fundamentos do método proposto}

A figura 1 reúne de modo sintético e didático os conceitos depreendidos da literatura que fundamentaram o método proposto, denominado "SER", para análise de sustentabilidade. Esta denominação refere-se aos termos segurança (S), energia (E) e rentabilidade (R). Neste esquema observa-se em um extremo a palavra sustentabilidade; na literatura pode-se observar que as diversas manifestações em torno dessa expressão evidenciam uma mudança de pensamento, apoiada pela necessidade urgente de repensar a produção agrícola.

Três pilares sustentam a maior parte dos conceitos de sustentabilidade mais modernos, -economia, sociedade e ambiente-, muito comumente expressos como viabilidade econômica, justiça social e adequação ambiental. A proposta "SER" de diagnóstico de sistemas de produção para fins de sustentabilidade fundamenta-se na eficácia, tendo como parâmetros a inserção, e a importância do setor para a sociedade; seu desempenho bio-fisico e sua capacidade de sobreviver em um mercado competitivo.

Os parâmetros propostos são, portanto, a SEGURANÇA ALIMENTAR (Sociedade), a ENERGIA (Ambiente) e a RENTABILIDADE (Economia) como se pode observar na figura le busca representar toda a base teórica, depreendida da literatura consultada e que fundamentou a elaboração do método. 


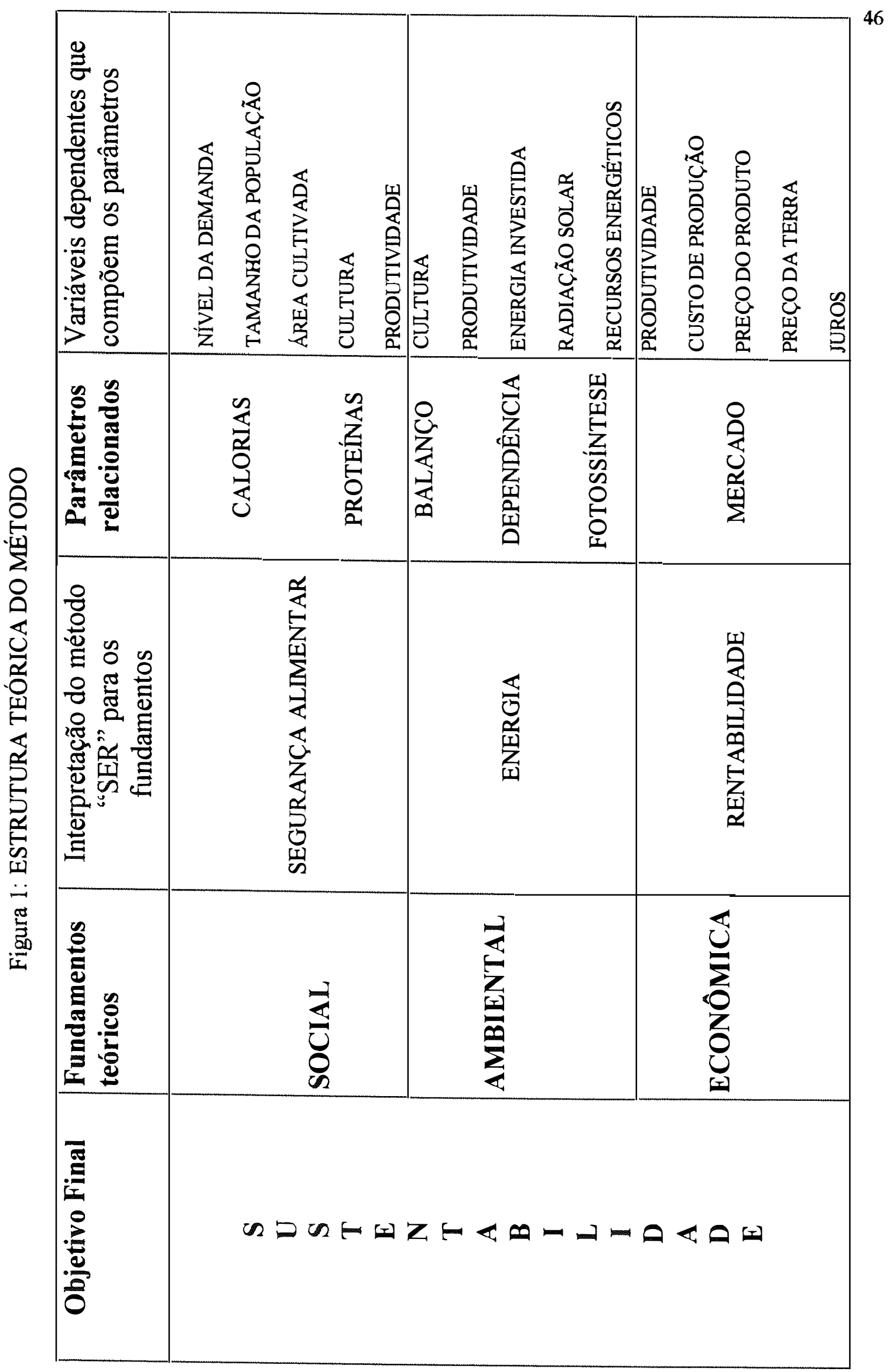


A proposta "SER" é um processo que exige a participação do agricultor, é necessário levantar-se aspectos do sistema que só ele conhece. Na tabela 6 pode-se analisar a proposta que é o resumo do método; na qual encontra-se a tradução prática, matemática, dos conceitos depreendidos como bases da sustentabilidade, organizados de forma a gerar o índice de sustentabilidade. O método proposto, conforme apresentado na tabela 6, deve ser copiado para um aplicativo como o EXCELL. As onze primeiras linhas constituem-se em variáveis dependentes de cada sistema de produção analisado e as linhas seguintes contém as fórmulas propostas no método.

Tabela 6: Resumo da tabela "SER"

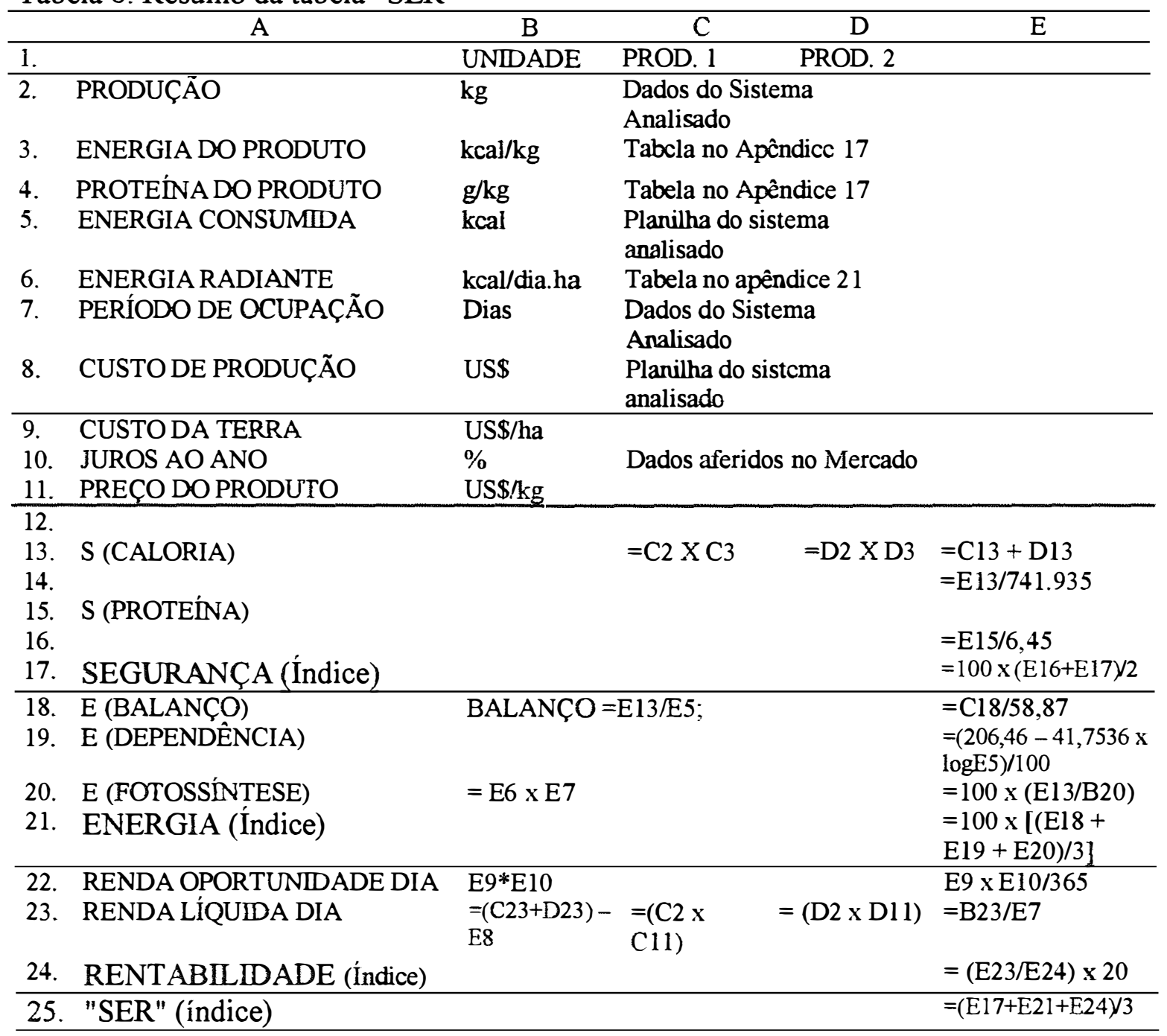

Na seqüência do texto é detalhado o procedimento utilizado para a geração da tabela e dos parâmetros considerados no processo. 


\subsubsection{Segurança alimentar}

A área cultivável é de 1.381 .917 .000 hectares $\left(1,382 \times 10^{9}\right)$, levantada pela FAO para o ano de 1996 que é, mas a área cultivada atualmente restringe-se a $0,31 \times 10^{9}$ ha. Esta área não tende a variar, seu aumento é bastante improvável, pelo contrário as pequenas variações ocorreram no sentido do decréscimo, principalmente em virtude de processos como salinização, desertificação e erosão destas áreas que, em muitas partes do mundo, vêm sofrendo um uso inadequado e altamente intensivo. A população mundial, atualmente, é de aproximadamente 6 bilhões de pessoas (agosto de 1999). A expectativa é que a população mundial estabilize-se em torno de 10 bilhões de pessoas nos próximos 50 anos.

\section{A)Máxima produtividade calórica possível.}

Existe um mínimo de calorias que uma área deva produzir para cumprir com sua função de garantir a segurança alimentar mundial. Este índice é uma função da demanda calórica mundial e da área plantada, esta, varia com o padrão de consumo de energia e com a população, como pode-se observar na tabela 7 .

Tabela 7: Consumo energético segundo níveis de demanda

\begin{tabular}{cccccccc}
\hline Padrão & \multicolumn{3}{c}{ Per capita } & \multicolumn{2}{c}{ População de 6 } & \multicolumn{2}{c}{$\begin{array}{c}\text { População de } 10 \\
\text { bilhões }\end{array}$} \\
Consumo & / dia & / ano & /dia & / ano & /dia & /ano \\
\hline Subsistência & $\mathrm{kcal}$ & Mcal & Pcal & Pcal & Pcal & Pcal \\
\cline { 2 - 7 } & 3.000 & 1095 & 18 & 6570 & 30 & 10950 \\
Padrão médio desenvolvimento & 6.300 & 2299,5 & 37,8 & 13797 & 63 & 22995 \\
Padrão médio & 15.000 & 5475 & 90 & 32850 & 150 & 54750 \\
Satisfacão básica & 32100 & 11716 & 192,6 & 70299 & 321 & 117165 \\
Padrão médio industrializado & 52.800 & 19272 & 316,8 & 115632 & 528 & 192720 \\
Padrão tecnológico & 230.000 & 83950 & 1380 & 503700 & 2300 & 839500 \\
\hline
\end{tabular}

A produtividade calórica por hectare para a sustentabilidade, para os diversos níveis de consumo e diferentes tamanhos da população, é portanto definida por estes 
padrões de demanda e podem ser observados na tabela 8 .

Tabela 8: Produção de energia por hectare para níveis de consumo

\begin{tabular}{|c|c|c|c|c|c|c|}
\hline Padrão: & & Médio em & & & Módio & \\
\hline \multirow{2}{*}{\multicolumn{7}{|c|}{ Dados em Mcal/ha }} \\
\hline & & & & & & \\
\hline \multicolumn{7}{|c|}{ População de 6 bilhões } \\
\hline por dia & 58 & 122 & 290 & 621 & 1021 & 4451 \\
\hline por ano & 21190 & 44500 & 10596 & 22670 & 373006 & 1624838 \\
\hline \multicolumn{7}{|c|}{ População de 10 bilhões } \\
\hline por dia & 97 & 203 & 483 & 1035 & 1703 & 7419 \\
\hline por ano & 35322 & 74177 & 176612 & 377951 & 621677 & 2708060 \\
\hline
\end{tabular}

\section{B)Máxima produtividade protéica possivel.}

Existe um mínimo de proteína que uma área deva produzir para cumprir com sua função de garantir a segurança alimentar mundial. Este índice é uma função da demanda protéica mundial e área plantada como pode-se observar na tabela 9

Tabela 9: Consumo protéico segundo níveis de demanda

\begin{tabular}{|c|c|c|c|c|c|c|}
\hline Padrão & \multicolumn{2}{|c|}{ Per copita } & \multicolumn{2}{|c|}{$\begin{array}{c}\text { População de } 6 \\
\text { bilhões }\end{array}$} & \multicolumn{2}{|c|}{$\begin{array}{l}\text { População de } \\
10 \text { bilhões }\end{array}$} \\
\hline Consumo & / dia & / ano & /dia & / ano & /dia & /ano \\
\hline & $\mathrm{g}$ & $\mathrm{kg}$ & 1000ton & 1000 ton & 1000 ton & 1000 ton \\
\hline Subsistência & 37 & 13,505 & 222 & 81030 & 370 & 135050 \\
\hline $\begin{array}{l}\text { Padrão médio } \\
\text { industrializado }\end{array}$ & 100 & 36,5 & 600 & 219000 & 1000 & 365000 \\
\hline Padrão tecnológico & 200 & 73 & 1200 & 438000 & 2000 & 730000 \\
\hline
\end{tabular}

A produtividade de proteína produzida por hectare, para atender aos diversos padrões de consumo é portanto uma função destes padrões, observados na tabela 9, e podem ser analisados na tabela 10 . 
Tabela 10: Produção de proteína por hectare para níveis de consumo

\begin{tabular}{lccr}
\hline Padrão & Subsistência & Médio industrializado & Tecnológico \\
\hline \multicolumn{4}{c}{ kg de proteína necessários por hectare } \\
\hline \multicolumn{3}{c}{ para 6 bilhões de habitantes } \\
\hline por dia & 0,72 & 1,94 & 3,87 \\
por ano & 261,39 & 706,45 & 1412,90 \\
\hline \multicolumn{3}{c}{ para 10 bilhões de habitantes } \\
\hline por dia & 1,19 & 3,23 & 6,45 \\
por ano & 435,65 & 1177,42 & 2354,84 \\
\hline
\end{tabular}

\subsubsection{2 Índice de Eficiência do Sistema para Segurança Alimentar (S)}

$$
\text { A = Energia produzida por dia por hectare } \div \mathbf{7 4 1 . 9 3 5} \mathrm{kcal}
$$

Caso o valor de energia consumida seja inferior a $58.064 \mathrm{kcal} / \mathrm{ha}$.dia (calorias suficientes para atender à subsistência de 6 bilhões de pessoas), o valor de A deve ser considerado igual a zero, pois o sistema não atende às necessidades de subsistência dos atuais 6 bilhões de pessoas. Se o valor da energia produzida por hectare por dia for superior a $741.935 \mathrm{kcal}$ (Calorias suficientes para atender ao padrão moderno para 10 bilhões de pessoas), o valor de A deverá ser igual a 1 . A tendência é que a utilização deste parâmetro praticamente impeça que possamos atingir um índice 1 para a energia produzida por hectare comparada à demanda. Isto conduz-nos à reflexão sobre a sustentabilidade de modelos de sociedade tão dependentes de consumo de energia e matéria. Menor consumo seria suficiente para a manutenção confortável das pessoas, mas manutenção não é o objetivo dentro de nossa sociedade.

A equação 2 determina $o$ valor de $B$ para a formação do índice para sustentabilidade.

$$
B=\text { Proteína produzida por dia por hectare } \div \mathbf{6 , 4 5}
$$

Caso o valor de proteína produzida seja inferior a $0,72 \mathrm{~kg} / \mathrm{ha}$.dia, o valor de B 
deve ser considerado igual a zero, pois o sistema não atende às necessidade de subsistência dos atuais 6 bilhões de pessoas. O valor que deve ser produzido por hectare, em um dia é 6,45 , proteína suficiente para a demanda "moderna" de 10 bilhões de pessoas.

A equação que determina o índice de segurança é a equação 3 .

$$
S=[(A+B) \div 2] \times 100
$$

Gomide et al. (1995) apresenta na tabela 11, os índices de produtividade atuais e potenciais para algumas culturas, estes dados servem de base para estimar-se a gravidade do problema que envolve os atuais níveis de consumo das populações dos países desenvolvidos:

Tabela 11: Produtividade atual e potencial para diferentes culturas

\begin{tabular}{lcccc}
\hline \multicolumn{1}{c}{ cultura } & \multicolumn{2}{c}{ Atual t/ha } & \multicolumn{2}{c}{ Potencial t/ha } \\
& Brasil & Cerrado & $\begin{array}{c}\text { Lavouras } \\
\text { tecnificadas }\end{array}$ & $\begin{array}{c}\text { Potencial } \\
\text { disponivel }\end{array}$ \\
\hline Milho & 2,0 & 2,0 & 7,6 & 13,6 \\
Soja & 1,8 & 2,0 & 4,0 & 5,0 \\
Feijão & 0,4 & 0,4 & 2,0 & 4,0 \\
Feijão irrigado & 1,3 & 1,6 & 2,5 & 4,2 \\
Arroz & 1,7 & 1,2 & 3,1 & 4,8 \\
Trigo & 1,7 & 2,0 & 2,7 & 3,5 \\
\hline
\end{tabular}

Duas culturas exemplares quanto ao potencial de atendimento às demandas da sociedade por energia e proteína são respectivamente a cultura do milho e a da soja. Tomamos como exemplo a cultura do milho para demonstrar o problema da sustentabilidade da agricultura, diretamente relacionado à questão da demanda da sociedade. O modelo técnológico moderno que implica em altíssimas demandas energéticas é inevitavelmente insustentável caso um dia todas as pessoas venham a tê-lo como padrão de qualidade de vida. 
Tabela 12: Potencial da cultura do milho para atender às demandas

\begin{tabular}{|c|c|c|c|}
\hline Produtividade & toneladas & & 13,6 \\
\hline Teor de Proteína & $\mathrm{g} / \mathrm{kg}$ & & 89 \\
\hline Teor de Calorias & $\mathrm{kcal} / \mathrm{kg}$ & & 3610 \\
\hline Produção de proteína & $\mathrm{kg} / \mathrm{dia}$ & & 10,09 \\
\hline Produção de calorias & $\mathrm{kcal} / \mathrm{dia}$ & & 409133 \\
\hline Demanda tecnológica por calorias & $\mathrm{kcal} / \mathrm{dia}$ & 4451612,90 & 0,092 \\
\hline Demanda média por calorias & $\mathrm{kcal} / \mathrm{dia}$ & 290322,60 & 1,41 \\
\hline Demanda subsistência por calorias & $\mathrm{kcal} / \mathrm{dia}$ & 58064,50 & 7,046 \\
\hline Demanda tecnológica por proteína & $\mathrm{kg} / \mathrm{dia}$ & 3,87 & 2,606 \\
\hline Demanda média por proteína & $\mathrm{kg} / \mathrm{dia}$ & 0,97 & 10,4 \\
\hline Demanda subsistência por proteína & $\mathrm{kg} / \mathrm{dia}$ & 0,72 & 14,01 \\
\hline Tempo de Ocupação & & 120 & \\
\hline
\end{tabular}

Como pode-se observar nos dados da tabela 12, para uma demanda considerada como sendo de subsistência, a produtividade potencial de calorias da cultura do milho poderia atender $705 \%$ uma população de 6 bilhões de pessoas e $140 \%$ a uma demanda média desta população, entretanto não bastaria para o abastecimento de $9 \%$ da população de 6 bilhões de pessoas caso esta tivesse uma demanda considerada tecnológica. Há, sem dúvida alguma, a necessidade de adequar-se os atuais padrões de consumo às possibilidades de atendimento pela agricultura.

\subsubsection{Energia}

Quanto à energia o método proposto considera como essenciais à agricultura sustentável os seguintes princípios :

\section{a) Baixa dependência de recursos energéticos externos à propriedade}

Depende do consumo energético médio por hectare na agricultura, da taxa de substituição das formas de energia. Como pode-se constatar na literatura, atualmente apenas $13 \%$ do abastecimento de energia no mundo é proveniente de fontes renováveis e 
seguras. A perspectiva mais otimista para os próximos 20 anos prevê uma elevação modesta do consumo e uma aumento da participação de outras fontes além das fósseis ou nucleares, de 13 para $42 \%$. A média das previsões dos diferentes cenários, indica um consumo de 13,93 Gtep/ano, sendo aproximadamente $76 \%$, ou seja $10,6 \mathrm{Gtep} / \mathrm{ano}$ consumidos na forma de combustíveis fósseis ou energia nuclear, 37,7\% maior que o consumo primário total atual. Só o consumo de petróleo representaria 3,6 Gtep/ano. Para as atuais estimativas de reservas, este consumo esgotaria a possibilidade de manutenção do fornecimento em 38,5 anos. A agricultura consome, em média, $8 \%$ da energia na sociedade e obedece aos padrões de estrutura de abastecimento da sociedade. A questão que o método deverá avaliar é: o sistema de produção analisado contribui para agravamento do quadro energético mundial, o mantém ou ajuda a diminuir o ônus da grande pressão sobre as reservas. Reduzir a pressão sobre as reservas significa aumentar o fôlego da sociedade, como um todo, para com o tempo, substituir energia nãorenováveis por renováveis e reduzir seus atuais padrões de consumo.

\section{b) Máximo balanço energético possível}

Este dado relata diretamente a taxa de eficiência da máquina (sistema) analisada com relação à segunda lei da termodinâmica. O dado também pode ser expresso em porcentagem. Reflete a capacidade daquele modo de produção e daquela cultura em transformar as energias antrópicas inseridas em produtos. Esta eficiência é um dado essencial à sustentabilidade na medida em que avalia a capacidade produtiva relacionada à degradação de energia do sistema.

\section{c) Máxima eficiência fotossintética possível.}

Esse dado é influenciado pelo manejo e pelo potencial do material genético utilizado. Sua aplicação à determinação do índice energético e consequentemente ao índice de sustentabilidade deve-se à percepção de que há custo de oportunidade associado à área e que este depende, em grande parte, da quantidade de energia radiante disponível em cada local e em cada época do ano. Uma área tropical no período de verão é uma oportunidade de geração de calorias e proteínas muito maior que a de uma área 
temperada em pleno inverno. A eficiência na transformação da energia solar é a medida que reflete a capacidade deste sistema de produção, no futuro, permitir que a sociedade viva de seu salário, o Sol.

Estes princípios têm sua formulação matemática apresentada no item 3.1.2.2, o qual contém o índice se eficiência do sistema para energia. $\mathrm{O}$ item a seguir apresenta as sugestões deste trabalho para a homogeneização dos dados energéticos para diversos bens e serviços utilizados na agricultura.

\subsubsection{Proposta de roteiro para a elaboração da análise energética}

Todos os passos propostos devem ser conduzidos pelo agricultor ou em parceria entre o técnico e o agricultor; o técnico deve, neste caso, agir como orientador, facilitando a compreensão do agricultor e dirimindo suas dúvidas.

Assim, a análise energética deverá contemplar as seguintes etapas:

I. Definir objetivos da análise

II. Identificar o sistema

III. Identificar os limites do sistema

IV. Ajustar a metodologia segundo o objetivo

V. Identificar as entradas e saídas do sistema

VI. Fazer a planilha de entradas e saídas

VII. Converter valores energéticos

VIII. Analisar resultado segundo objetivo

IX. Analisar a planilha segundo objetivo

X. Concluir tentando orientar modificações no sistema.

A primeira questão que emerge ao se iniciar uma análise energética em um agroecossistema trata dos limites deste sistema. O outro passo que se faz necessário para a confecção da planilha de análise energética é a identificação de entradas e saídas e 
formação da planilha. Para isso faz-se necessário:

\section{a. Análise dos Investimentos energéticos}

A análise dos investimentos energéticos do sistema de produção em questão exige que estes sejam identificados, convertidos em valores energéticos e contabilizados.

Investimentos energéticos são todas as entradas de bens ou serviços dentro da unidade de estudo ou sistema. Os limites dependem do objeto de estudo, podem ser uma gleba de uma propriedade ou podem ser toda uma propriedade, podem inclusive ser todo um estado ou país.

\section{b. Análise dos Produtos}

A análise dos Produtos também depende de que estes sejam identificados, convertidos em valores energéticos e contabilizados. Esta metodologia propõe uma análise em função do valor calórico e do teor de proteína dos produtos.

\subsection{Determinação dos valores adotados}

Como pode-se constatar a partir da análise da literatura disponivel, existe a necessidade de uniformização dos valores energéticos adotados para bens e serviços. É muito importante que os trabalhos feitos neste campo possam ser comparados sem necessidade de correções. Neste trabalho, encontra-se uma revisão dos valores utilizados para os principais insumos e serviços na agricultura.

Muitos trabalhos são feitos nas indústrias para determinação desses valores, os dados referentes a insumos industrializados, geralmente, variam muito pouco; as pequenas variações devem-se às diferenças das instalações de cada indústria e às vezes do processo utilizado. Para estas variações o importante é seguir alguns critérios para a escolha de diferentes valores. As dificuldades na determinação dos valores energéticos para as atividades agrícolas referem-se principalmente aos bens e serviços nos quais o critério adotado influencia muito no valor energético, como por exemplo, para sementes, trabalho humano e terra. 
Neste trabalho, a idéia é disponibilizar valores que possibilitem a aplicação direta e simples pelo usuário do método. Não há como determinar-se exatamente a quantidade de energia necessária a um sistema de produção; mais importante é a ordem de grandeza da intensidade energética e sua relação com a produtividade.

Para os insumos industriais, deverão ser utilizados valores mais altos, quando for necessário refletir fatores não expressos na simples intensidade energética do bem como potencial poluidor, necessidade de transporte a longas distâncias, depleção de recursos não-renováveis. Através deste critério não se pretende seguir a linha proposta por Odum de adotar-se valores em FFE (Equivalente de Combustível Fóssil), na qual o valor energético reflita aspectos sociais, econômicos e ambientais do bem ou serviço, a intenção é tão somente estabelecer-se um critério que permita uniformizar os valores adotados aproximando-os um pouco mais de sua realidade quanto a fatores ecológicos, principalmente quanto à energia. A adoção deste critério não exclui, muito pelo contrário, sugere, a necessidade de se aprimorar as avaliações de sustentabilidade dos sistemas de produção incluindo nelas outros parâmetros, além de energia, que melhor expressem sua posição quanto à sustentabilidade ecológica, econômica e social.

Sempre que o usuário do método não encontrar um valor confiável para um insumo ou serviço deverá decidir-se dentre duas possibilidades:

1) Fazer uma análise do processo que gerou o investimento energético em questão, e determinar, assim, com razoável precisão, o valor energético;

2) Converter o valor segundo a matriz energética brasileira, ou seja, 10.141 $\mathrm{kcal} /$ US\$. Este valor apesar de genérico não compromete o resultado da análise final, a não ser que o valor resultante represente uma porcentagem muito alta, acima de 20$30 \%$ do custo energético total.

A revisão bibliográfica contida neste trabalho permite que os usuários do método possam, caso julguem necessário, calcular os valores energéticos de bens ou serviços não discriminados na proposta ou que necessitem de um valor mais específico para a análise de seu sistema de produção.

Os valores adotados podem ser determinados através de análise de processo, matriz energética ou segundo o valor de algum produto correlato. 
Os valores de serviços não indicados neste trabalho devem ser gerados através de análises de processo. A complexidade da análise dependerá do nível de precisão desejado.

A tabela 14 apresenta um resumo dos fatores de conversão de energia para a maioria dos insumos utilizados na agricultura. Os critérios que orientaram a determinação destes valores podem ser encontrados na discussão do método, os dados que fundamentaram os cálculos encontram-se na revisão bibliográfica e nos apêndices.

A tabela 15 apresenta os valores determinados para a conversão dos serviços mais utilizados na agricultura; a tabela 13 contém a sugestão de valores para conversão da energia contida na irrigação em função do recalque exigido e do sistema de irrigação utilizado. Assim como para a tabela 14, os critérios que fundamentaram a elaboração destes valores encontram-se no item de discussão deste trabalho e os valores nos apêndices e na revisão bibliográfica.

Os valores encontrados na tabelas 13,14 e 15 são suficientes para a elaboração da planilha energética dos investimentos energéticos. Os valores para conversão energética dos produtos pode ser encontrados no apêndice 17. Assim, o usuário do método pode compor sua análise energética. A partir desta análise pode-se caminhar para a obtenção do índice de eficiência do sistema para energia.

Tabela 13: Fatores de conversão de energia para sistemas de irrigação em função do recalque

\begin{tabular}{cccc}
\hline Energia: & $\begin{array}{c}\text { Recalque } \\
10 \mathrm{~m}\end{array}$ & $\begin{array}{c}\text { Recalque } \\
50 \mathrm{~m}\end{array}$ & $\begin{array}{c}\text { Recalque } \\
100 \mathrm{~m}\end{array}$ \\
\cline { 2 - 4 } Sistema x recalque & \multicolumn{3}{c}{$\mathrm{kcal} / \mathrm{mm}$.hectare } \\
\hline Superficie & 30 & 129 & 437 \\
Pivot & 338 & 378 & 735 \\
Aspersão & 338 & 378 & 735 \\
Gotejamento & 270 & 308 & 616 \\
\hline
\end{tabular}


Tabela 14: Fatores de conversão de energia para insumos diversos

\begin{tabular}{|c|c|c|}
\hline \multicolumn{3}{|c|}{ FATORES DE CONVERSÃO PARA SEMENTES E OUTROS PROPÁGULOS } \\
\hline & Exemplo & Valor adotado \\
\hline Semente de alta tecnologia & Semente milho hibrido & $2 \times$ o valor calórico da semente \\
\hline Semente de baixa tecnologia & Milho de paiol & $=$ valor calórico da semente \\
\hline Propágulo ("resto cultural") & Maniva de mandioca & $0 \mathrm{kcal} / \mathrm{kg}$ \\
\hline Propágulo - produto & Batata - semente & Valor calórico do produto \\
\hline Mudas & Muda de eucalipto & Fazer análise de processo \\
\hline Propágulo adquirido & Maniva comprada & Peso x $15 \mathrm{kcal} / \mathrm{kg}$ \\
\hline \multicolumn{3}{|c|}{ FATORES DE CONVERSÃO PARA CORRETIVOS E FERTILIZANTES } \\
\hline NITROGENADOS & $\mathrm{N}$ & Mcal/t ou kcal/kg \\
\hline $\mathrm{N}$ & 100 & 25.000 \\
\hline Uréia & 45 & 18.643 \\
\hline Nitrato de Amônio & 34 & 18.403 \\
\hline Nitrato de Cálcio & 16 & 4.000 \\
\hline Amônia anidra & 82 & 16.252 \\
\hline Sulfato dc amônio & 21 & 5.250 \\
\hline Nitrato de Potássio & 14 & 3.500 \\
\hline FOSFÓRICOS & $\mathrm{P}_{2} \mathrm{O}_{5}$ & $\mathrm{kcal} / \mathrm{kg}$ ou Mcal/t \\
\hline $\mathrm{P}_{2} \mathrm{O}_{5}$ & 100 & 3.000 \\
\hline Super Fosfato Simples & 21 & 2.340 \\
\hline Super Fosfato Triplo & 48 & 5.282 \\
\hline Termofosfato & 30 & 900 \\
\hline Fosfato de rocha & 5 & 150 \\
\hline $\mathrm{P}$ & 114 & 3.384 \\
\hline POTÁSSICOS & $\mathrm{K}_{2} \mathrm{O}$ & $\mathrm{kcal} / \mathrm{kg}$ ou Mcal/t \\
\hline $\mathrm{K}_{2} \mathrm{O}$ & 100 & 1.600 \\
\hline Sulfato de Potássio & 50 & 800 \\
\hline $\mathrm{KCl}$ & 60 & 1.718 \\
\hline Sulfato deK e Mg & 25 & 400 \\
\hline Calcário & $\mathrm{kcal} / \mathrm{kg}$ ou Mcal/t & 400 \\
\hline Micronutrientes & kcal/US\$ & 10.141 \\
\hline \multicolumn{3}{|c|}{ FATORES DE CONVERSÃO DE ENERGIA PARA DEFENSIVOS } \\
\hline Inseticida & & 86.910 \\
\hline Formicida & & 46.270 \\
\hline Fungicida & $\mathrm{kcal} / \mathrm{kg}$ & 73.260 \\
\hline Hcrbicida & & 99.910 \\
\hline \multicolumn{3}{|c|}{ FATORES DE CONVERSÃO PARA OUTROS INSUMOS } \\
\hline Esterco Bovino Úmido & & 15 \\
\hline Esterco Bovino Seco & & 30 \\
\hline Outros tipos de esterco & & 30 \\
\hline Saco Polipropileno & $\mathrm{kcal} / \mathrm{kg}$ & $25.979,92$ \\
\hline Mulch plástico & & $2.275,33$ \\
\hline Grafite & & 7.800 \\
\hline Outros & $10.141 \mathrm{kcal} / \mathrm{US} \$ \mathrm{ou}$ & nálise de processo específica \\
\hline
\end{tabular}


Tabela 15: Fatores de conversão de energia para serviços diversos

\begin{tabular}{|c|c|}
\hline \multicolumn{2}{|c|}{$\begin{array}{l}\text { ARA OPERAÇÕES COM TRAÇÃO ANIMAL } \\
\text { kcal/hectare }\end{array}$} \\
\hline Aração & \\
\hline Gradagem & 10.800 \\
\hline Pulverização & 5.400 \\
\hline Semeadura & 9.450 \\
\hline Fertilização & 4.050 \\
\hline Capina & 10.800 \\
\hline Colheita & 1.350 .000 \\
\hline \multicolumn{2}{|c|}{$\begin{array}{l}\text { FATORES DE CONVERSÃO PARA OPERAÇÕES MECÂNICAS } \\
\text { kcal/hectare }\end{array}$} \\
\hline Aração & 136.010 \\
\hline Gradagem & $47.975,5$ \\
\hline Pulverização & 10.035 \\
\hline Semeadura & $31.536,5$ \\
\hline Cultivo & 142.209 \\
\hline Colheita & 168.463 \\
\hline Manutenção de Terraços & 27.567 \\
\hline \multicolumn{2}{|c|}{$\begin{array}{l}\text { FATORES DE CONVERSÃO PARA TRANSPORTE } \\
\text { kcal/tonelada.km }\end{array}$} \\
\hline Rodoviário & 1.040 \\
\hline Ferroviário & 201 . \\
\hline Hidroviário & 201 \\
\hline Aéreo & 7.242 \\
\hline
\end{tabular}

\subsubsection{2 Índice de Efíciência do Sistema para Energia (E)}

\section{a) Balanço energético}

Caso o balanço energético seja superior a 58,87, o valor de A é igual a 1 .

$\mathrm{O}$ balanço ideal deve refletir no mínimo um produto, em termos de energia, que atenda à subsistência dos atuais 6 bilhões de pessoas, produzido com investimentos que não ultrapassem $8 \%$ do consumo de energia primária total que a agricultura anualmente consome nos 0,31 x 109 ha. Ou seja, o balanço ideal é :

$21.193,55 \mathrm{Mcal} / \mathrm{ha} \div 360 \mathrm{Mcal} / \mathrm{ha}=\mathbf{5 8 , 8 7}$ 
Portanto, sendo o balanço energético ideal igual a 58,87, o índice que refletirá a eficiência obedece à equação 4 :

$$
A=(\text { Balanço do Sistema Analisado } \div 58,87)
$$

\section{b) Nivel de dependência}

O nível de dependência está diretamente relacionado à área de terra cultivada e à porcentagem de consumo energético da agricultura do total da sociedade. A tabela a seguir apresenta o consumo de energia médio por hectare se considerarmos vários níveis de consumo, de $8 \%$ do total anual até $100 \%$ das reservas mundiais.

Tabela 16: Energia disponivel por hectare

\begin{tabular}{lcc}
\hline \multirow{2}{*}{ Nivel de Consumo } & \multicolumn{2}{c}{ Área cultivada de $0,31 \times 10^{9}$ ha } \\
\cline { 2 - 3 } & tep/ha.ano & Mcal/ha.ano \\
\hline $1,1144 \times 10^{9}$ tep & 3,595 & 360 \\
$13,93 \times 10^{9}$ tep & 44,94 & 4.494 \\
$138,5 \times 10^{9}$ tep & 446,8 & 44.677 \\
$277 \times 10^{9}$ tep & 893,5 & 89.355 \\
\hline
\end{tabular}

Quanto ao nível de dependência, o modelo de agricultura desenvolvido pode manter os catastróficos padrões de consumo da sociedade, piorá-los ou contribuir para uma melhoria das perspectivas de sustentabilidade da sociedade moderna. Frente a uma perspectiva de abastecimento energético de apenas 38,5 anos, considerando um padrão de participação no consumo energético de $8 \%$ por parte da agricultura com um consumo primário total de 13,93 Gtep/ano, a agricultura não seria um fator de agravamento no quadro mundial da energia se seu consumo mundial total não ultrapassasse 1,1144 Gtep/ano. Para uma área arável total de $1,382 \times 10^{9}$, o consumo de energia por área não deveria superar 0,80637 tep/ha.ano (0,080637 Gcal/ha.ano, ou 80,637 Mcal/ha.ano). Entretanto, a área atualmente cultivada é de 0,31 x 109 ha, para que não precisemos expandir as área de cultivo, ou seja provocar maior perda de biodiversidade e emissão de carbono na atmosfera, o consumo de energia não deveria superar 359,484 Mcal/ha.ano. 
O consumo anual de energia na agricultura, atualmente equivale a $8 \%$ do consumo primário total do mundo (13,93 × $10^{9}$ tep), ou seja $1,1144 \times 10^{9}$ tep. A energia fóssil restante no mundo é de $138,5 \times 10^{9}$ tep; como em geral o consumo de energia é $50 \%$ fundamentado em energia fóssil, consideramos que ao consumir-se, no mundo, 277 $\times 10^{9}$ tep todo o combustível fóssil mundial estará liquidado.

Esta proposta considera este consumo de $277 \times 10^{9}$ tep como sendo trágico; caso todos os sistemas de produção consumissem $89.355 \mathrm{Mcal} / \mathrm{ha}$, a energia fóssil terminaria apenas com as atividades agrícolas em um ciclo produtivo; valores iguais ou maiores que este não atendem em nada a sustentabilidade de um sistema de produção quanto à sua dependência por recursos energéticos. O consumo de $360 \mathrm{Mcal} / \mathrm{ha}$ por sua vez faz com que o sistema de produção esteja adequado ao atual nível de consumo energético da sociedade, não que este seja em si sustentável; para esta proposta consideraremos que sistemas de produção com valores de consumo energético iguais ou menores que este atendem $100 \%$ da sustentabilidade na agricultura.

A distância entre um consumo de $89.355 \mathrm{Mcal} / \mathrm{ha}$ e de $360 \mathrm{Mcal} / \mathrm{ha}$ é muito grande; os danos à sustentabilidade para todo aumento de energia acima de $360 \mathrm{Mcal} / \mathrm{ha}$ é muito grande; assim aumenta exponencialmente as perspectivas de insustentabilidade energética da agricultura. Por isto a função foi linearizada através da conversão em equação logarítmica para que reflita mais adequadamente as implicações do consumo acima de $360 \mathrm{Mcal} / \mathrm{ha}$.

$\log 360$, ou seja 2,556 representa $100 \%$ de atendimento enquanto $\log 89.355$, ou seja 4,951 , representa $0 \%$ de atendimento.

Os investimentos energéticos devem ser transformados em um logarítmo base 10 que se situará entre 2,556 e 4,951, e será a variável independente da equação da reta (x).

$O$ coeficiente angular da reta é a tangente do ângulo oposto.

A tangente de $\alpha$ (alfa) é a razão entre o cateto oposto e o cateto adjacente, ou seja, conforme a equação 5 :

$$
(100-0) \div(2,556-4,951)=\mathbf{- 4 1 , 7 5 3 6}=\alpha
$$

O ângulo da reta que representa a equação é de $89^{\circ} 26^{\prime} 49^{\prime \prime}$.

Para o consumo de 86.935 Mcal temos a equação 6: 


$$
Y=a+b x, \text { ou seja, }
$$

$$
0=a+(-41,7536 * 4,951)
$$

Portanto, $a=\mathbf{2 0 6 , 4 6 .}$

A equação através da qual definiremos o índice para o nível de dependência do sistema de produção é definida pela equação 7 :

$$
B=(206,46-41,7536 * \log \text { Investimentos }) \div 100
$$

\section{c) Eficiência fotossintética}

A eficiência fotossintética (EF) é calculada aqui em função da radiação incidente e da energia obtida no processo.

Coombs et al. (1983) apresentam uma série de médias de eficiência fotossintética para várias culturas, nesta plantas $\mathrm{C} 3$ como a batata apresenta uma eficiência média de $0,5 \%$, e plantas $\mathrm{C} 4$ entre 0,6 e 0,7\% como milho e sorgo respectivamente, algumas culturas como cana-de-açúcar (C4) e beterraba (C3) chegam à uma eficiência próxima e até acima de $1 \%$ em alguns casos devido ao grande potencial de conversão de energia em açucares simples. Como a maioria das culturas tem uma eficiência fotossintética (EF) abaixo de 1\%, consideraremos este valor como o $100 \%$ de sustentabilidade. A EF é calculada dividindo-se a produtividade de energia do sistema pelo total de energia radiante incidente durante o período de ocupação da cultura. A energia radiante deve ser considerada segundo a latitude e a época do ano, obtida em tabela neste mesmo trabalho; ou mesmo com postos metereológicos locais. Portanto o índice que representa a eficiência energética é obtido através da equação 8:

$$
C=\operatorname{EF} \times 100
$$

O índice de sustentabilidade para energia é a média dos três parâmetros apresentados acima. Logo pode ser representado pela equação 9: 


$$
E=[(A+B+C) \div 3] \times 100
$$

\subsubsection{Rentabilidade}

Não há como garantir a sustentabilidade da atividade agrícola sem se considerar a rentabilidade obtida pelo agricultor. $\mathrm{O}$ investimento na agricultura possui mais riscos que outros investimentos, a gerência na agricultura é desgastante. Se a rentabilidade obtida na atividade agrícola não superar a rentabilidade que o agricultor poderia obter caso vendesse suas terras e aplicasse o montante da venda no mercado, este, certamente, fará a opção de abandonar a agricultura. Caso este tipo de fato ocorra com freqüência e em grande intensidade no mundo a sustentabilidade da agricultura estará ameaçada. Consequentemente, o índice da sustentabilidade de um sistema de produção deve considerar a rentabilidade. O objetivo, no caso é a máxima lucratividade possível. A tabela 17 expõe preços de terra e taxas de juro comuns no mercado que compõem a formação do índice para rentabilidade. Os valores entre US\$ 50,00 e US\$ 500,00 são os mais realistas, os preços de terra mais reais são aqueles entre US\$500 e 2.000 por hectare e as taxas de juro entre 10 e $25 \%$ ao ano.

Tabela 17: Custo de oportunidade da terra em função de preço e taxas de juros

\begin{tabular}{ccccccc}
\hline \multicolumn{7}{c}{ Retomo financeiro por hectare.ano (US\$) } \\
\hline Custo & \multicolumn{7}{c}{ Taxa de Juros Anual(\%) } \\
\hline US\$/ha & 5 & 10 & 15 & 20 & 25 & 30 \\
\hline 250 & 12,5 & 25 & 37,5 & 50 & 62,5 & 75 \\
500 & 25 & 50 & 75 & 100 & 125 & 150 \\
1000 & 50 & 100 & 150 & 200 & 250 & 300 \\
1500 & 75 & 150 & 225 & 300 & 375 & 450 \\
2000 & 100 & 200 & 300 & 400 & 500 & 600 \\
3000 & 150 & 300 & 450 & 600 & 750 & 900 \\
5000 & 250 & 500 & 750 & 1000 & 1250 & 1500 \\
\hline
\end{tabular}




\subsubsection{1 Índice de Eficiência do Sistema para Rentabilidade (R)}

Consideramos que nenhum agricultor abandonará a atividade se esta propiciar um rendimento acima de cinco vezes a oportunidade de rentabilidade através da venda da terra e aplicação do valor auferido no mercado de capitais. Assim, o índice que representa a rentabilidade no método proposto é obtido pela equação 10 .

$$
R=(B \div A) \times 20
$$

Onde: A é o Custo de oportunidade por dia $=$ [Custo da terra/ha $\times$ Juros ao ano]/365 e,

B é a Rentabilidade líquida por dia $=($ Renda Bruta - Custo de produção $) /$ tempo de ocupação da cultura ou sistema avaliado.

Caso o valor de B/A seja igual ou maior que cinco o índice R será 100.

Para pequenas propriedades familiares a rentabilidade deve ser calculada de outra forma, muitas vezes, nelas encontramos sistemas de produção intrincados que visam a comercialização, a troca e a subsistência da família. A sustentabilidade econômica, neste caso, deve ser avaliada considerando-se todos estes fatores que contribuem para a compreensão da rentabilidade de tais sistemas de produção.

\subsubsection{Pressupostos para a validade dos parâmetros do método}

A validade do método proposto depende de que alogumas condições permaneçam inalteradas:

1. A área cultivada não será ampliada em defesa das áreas naturais restantes.

2. Os processos de desertificação e salinização serão totalmente contidos, ou o aumento de área cultivada será equivalente aos processos de perda de área.

3. Não haverão explosões populacionais ou mortandades em massa a níveis que desmintam todas as hipóteses formuladas pelos organismos internacionais para as 
estimativas populacionais.

4. O desenvolvimento de tecnologias não superará as previsões mais otimistas quanto à substituição de energias não-renováveis ou inseguros por formas renováveis.

O índice "SER" é considerado como sendo a média dos índices para Segurança, Energia e Rentabilidade; refletindo assim, a igual importância dos parâmetros. Portanto pode ser representado pela equação 11 .

$$
[(\mathrm{S}+\mathrm{E}+\mathrm{R}) \div 3]=\mathrm{SER}
$$

\subsubsection{Prescrições para uso do método}

O processo de diagnose é uma ação poderosa que, se bem conduzida, pode promover uma reflexão construtiva sobre a realidade por parte de quem dela depende e ela constrói. A utilização de um método de avaliação de sistemas de produção, com agricultores e técnicos, é uma ferramenta útil na promoção da visão crítica sobre o processo agrícola, suas funções e implicações, sob uma perspectiva mais ampla por parte dos tomadores de decisão. Quem melhor conhece o sistema são as pessoas que nele trabalham; ao técnico cabe facilitar um processo de descoberta ou redescoberta do sistema e de suas características.

A visão cartesiana que nos permitiu analisar problemas e propor soluções com maior precisão tirou-nos a capacidade de entender o mundo, seus objetos e fenômenos como um todo interdependente. $\mathrm{O}$ procedimento analítico propõe o estudo das partes separadamente, supondo que a reunião destas constitui ou reconstitui o todo.

Sistema, segundo diversos autores é uma inter-relação entre elementos que constituem uma entidade ou unidade global, ou ainda, um arranjo de componentes físicos, um conjunto ou coleção de coisas, unidas ou relacionadas de tal maneira que formam um todo.

A visão sistêmica da propriedade implica num reconhecimento da importância de 
fatores que vinham sendo desconsiderados ou desvalorizados em análises de seções da propriedade ou do sistema.

$\mathrm{O}$ reconhecimento da insustentabilidade do sistema de produção vigente na propriedade ou região não implica, de forma alguma, numa mudança de posturas. A análise do agroecossistema para fins de sustentabilidade é por si só um processo educativo ou orientador para o agricultor. Entretanto, identificar um problema pode não ser motivo suficiente para que este agricultor queira modificar seu sistema de produção porque:

1) A relevância do problema não é reconhecida

2) A eficiência da técnica de análise, e portanto seus resultados não lhe parecem confiáveis

O segundo problema pode ser resolvido mais facilmente a partir do momento em que alguns técnicos e agricultores utilizarem a técnica e apresentarem resultados que os demais agricultores, que ainda não a adotaram, reconheçam como algo desejável para suas propriedades ou para seus critérios de decisão (envolvam ou não a questão de responsabilidade para com o meio ambiente, ou meio social).

O não reconhecimento do problema torna-se uma questão muito mais séria a partir do momento que o agricultor mostre indiferença para questões como responsabilidade para com consumidores, concidadãos e para com as gerações futuras. Responsabilidade ou compromisso para com o meio, seja ele o meio social ou natural é diretamente proporcional à responsabilidade do meio para com o indivíduo. $\mathrm{O}$ agricultor precisa ser sensibilizado para as questões sociais e ambientais, isto exige técnicos atentos à estas questões que se disponham a trabalhar como educadores ambientais junto aos agricultores.

$O$ resultado que indicaria sustentabilidade plena da agricultura seria o indice "SER" 100 , ou seja $100 \%$ de sustentabilidade quanto à demanda da sociedade de 10 bilhões de pessoas, quanto ao uso de energia antrópica e natural e quanto à lucratividade do agricultor. Nos atuais sistemas de produção este índice é praticamente inatingível. O que deve se buscar é a melhoria contínua deste índice. $O$ método pode ser utilizado das seguintes maneiras: 


\section{A) Estudos Comparativos entre sistemas de produção ou entre glebas}

A análise de sustentabilidade segundo o método proposto pode ser aplicada ao estudo de diferentes formas de manejo ou técnicas aplicadas a uma mesma cultura. Aplica-se ao estudo de safras para a comparação de diferentes manejos e/ou para a comparação da mesma cultura ao longo de diversas safras.

Quando a eficiência energética for comparativamente inferior, principalmente quanto ao balanço energético, é interessante proceder-se à sua avaliação para encontrar práticas que oneram o sistema acima do normal e que provavelmente não estão propiciando o retorno adequado. Esta análise faz um maior sentido caso a piora do índice "SER" seja significativa; caso contrário a piora da eficiência energética pode ser uma opção do agricultor em beneficio da rentabilidade e produtividade, que uma prática, mesmo que energéticamente ineficiente, pode promover.

Este modo de uso do método aplica-se especialmente a agricultores e técnicos de um determinado setor da agricultura, como canavieiro, florestal, cerealista ou horticultor. Neste caso poderiam ser disponibilizados resultados na forma de publicações, home page do setor (trigo e cana por exemplo possuem), para contribuir com as comparações.

\section{B) Análise de sistemas diversificados ou da propriedade como um todo}

Neste caso, a análise deve compreender todo ano agrícola, e incluir todas as entradas e saídas do sistema, ou propriedade, como um todo. É interessante realizar-se Comparações entre vários anos agrícolas subsequentes de um sistema de produção

Pode ser útil observar como o índice e seus componentes variam ao longo de vários anos de análise. A variação da rentabilidade, da produtividade da eficiência quanto à energia e do balanço energético isoladamente permite a avaliação da melhora ou deterioração desses índices. No caso da piora referir-se ao balanço energético, é interessante notar quais os itens que mais contribuíram com o fato, esta análise permite avaliações como: a) Piora nos gastos com defesa fitossanitária indicam uma deficiência nos aspectos da biodiversidade do sistema de produção; b) Aumento nos gastos com 
fertilização química podem indicar problemas de perdas excessivas de solo no sistema e um problema de conservação e c) Piora nos gastos com mecanização podem indicar que estas práticas estão sendo usadas em excesso, sem o respectivo retorno, incluindo talvez uma piora nas características fisicas do solo.

Esta forma de utilização do método aplica-se de modo geral a agricultores e extensionistas; neste caso o mais importante é a reflexão por parte dos tomadores de decisão, os índices podem orientar as reflexões e as novas decisões.

\section{C) Identificação de problemas nos sistemas de produção}

A análise de uma tabela de valores energéticos de um sistema de produção permite compará-lo com outros quanto à proporção dentre os diferentes investimentos. Esta análise pode indicar-nos quais os fatores críticos no sistema, quando comparados a sistemas eficientes tanto energética quanto economicamente. Um gasto muito acima do normal com fertilizantes, herbicidas ou praguicidas podem indicar uma falha no manejo quanto nutrição das plantas, manejo de solos ou diversidade da produção, respectivamente. Aplica-se ao estudo de safras, o que pode permitir a Comparação de uma cultura com o padrão regional.

Ao perceber uma grande discrepância nos índices de uma determinada propriedade, a análise cuidadosa de suas práticas pode servir para identificar onde estão os possiveis grandes erros ou acertos que o agricultor esteja realizando.

Também pode ser útil para agricultores e extensionistas, além da reflexão por parte de cada agricultor, seria importante divulgar os resultados através dos técnicos de extensão da região.

\subsection{Validação do método}

Para a validação do método foram avaliados os sistemas de produção implantados na Fazenda Três Irmãos, em Santa Helena, sudoeste do Estado de Goiás, onde o solo vem sendo cultivado por seis anos, no sistema de plantio direto. Esta 
localidade encontra-se a $17^{\circ} 48^{\prime} 49^{\prime \prime}$ de latitude sul e $50^{\circ} 35^{\prime} 49^{\prime \prime}$ de longitude oeste em uma altitude de aproximadamente $615 \mathrm{~m}$ acima do nível do mar, sendo o clima predominante o tipo Aw, tropical e chuvoso. A radiação solar varia em torno de 450 $\mathrm{cal} / \mathrm{cm}^{2} / \mathrm{dia}$ (Goedert, 1980). O solo é classificado como Latossolo Roxo eutrófico, com textura franco-arenosa nos primeiros $20 \mathrm{~cm}$ e argilosa entre 20 e $40 \mathrm{~cm}$ de profundidade.

Para a validação do método foram empregados dois métodos de manejo do solo: plantio direto e gradagem com grade aradora $(0-0,1 \mathrm{~m})$; bem como dois níveis diferentes de adubação; um deles determinado pela equivalência da expectativa da exportação (rendimento médio obtido na propriedade - EG) e o outro prescindindo da adubação potássica e fosfórica. O controle de doenças, pragas e de plantas daninhas foram executados de acordo com a necessidade, segundo padrões comumente utilizados em áreas comerciais.

Foram utilizados os métodos de cálculo para as entradas de energia para trabalho humano, fertilizantes, corretivos, sementes, defensivos, máquinas (combustíveis e energia incorporada nas máquinas), e implementos descritos neste trabalho (encontra-se no item metodologia). Neste método considera-se a entrada de energia direta (relacionada ao uso de combustíveis e energia elétrica por exemplo) e energia indireta (na qual se considera a energia incorporada na fabricação/realização de um bem ou serviço). Foi realizado o acompanhamento de todas as atividades do processo produtivo, do preparo do solo à colheita, coletando todas as informações necessárias à avaliação da entrada de energia de cada bem e serviço utilizado segundo o método supracitado.

$\mathrm{Na}$ colheita foram considerados dados de população final e rendimento de grãos. Considerando valores calóricos médios (já existentes na literatura) para os grãos produzidos, foi obtida a saída da energia em grãos; à este valor foi acrescentado o efeito químico residual da adubação convertido em valores energéticos (efeito que também pode ser negativo), obtendo assim a soma total de energia do sistema.

A tabela 18, apresenta os sistemas que foram avaliados para a validação do método proposto, assim como a denominação, ou sigla, que foi aplicada a cada um deles, as primeiras duas letras indicam o manejo de solo (PD ou GA) e as seguintes a fertilização (EG ou T). 
Tabela 18: Sistemas avaliados para validação do método "SER"

\begin{tabular}{lll}
\hline 1. & Plantio Direto Adubação T & PDT \\
2. & Plantio Direto Adubação EG & PDEG \\
3. & Grade Aradora Adubação T & GAT \\
4. & Grade Aradora Adubação EG & GAEG \\
\hline
\end{tabular}

Foi utilizado o Milho híbrido BR 3123, um híbrido triplo apresentando ciclo de 63 dias para o florescimento, altura média de $2,2 \mathrm{~m}$, ciclo até a maturidade fisiológica 130 dias, altura média de inserção das espigas de $1,25 \mathrm{~m}$, grãos semi-duros e resistente ao acamamento.

O espaçamento entre linhas foi de $90 \mathrm{~cm}$ e a densidade de semeadura de 7-8 sementes por metro linear. A população média dos tratamentos foi de 58.850 plantas por hectare, sendo que não houve diferença significativa entre eles que pudesse afetar a análise comparativa.

As sementes foram tratadas com 2,0 1 de Furazin/100kg de sementes acrescido de $0,5 \mathrm{~kg}$ de grafite.

Para o controle de insetos-praga foram feitas com aplicações de Lorsban e Karatê quando necessário, sendo que todos os sistemas exigiram controles.

No sistema de plantio direto foi empregada a dessecação dos restos de cultura e plantas invasoras antes da semeadura. Para esta atividade foi utilizada a pulverização química com Glifosate na dosagem de 2 litros por hectare.

Foi utilizada uma grade aradora com 20 discos lisos com diâmetro de $66 \mathrm{~cm}$, marca SuperTatu, modelo CR 1820. O implemento foi tracionado por trator de $80 \mathrm{HP} \mathrm{e} \mathrm{a}$ profundidade média de trabalho foi de $14 \mathrm{~cm}$. Após a operação de manejo de solo foi feita uma pulverização com 2 litros de gramocil por hectare.

As operações de manejo de solo foram realizadas simultaneamente com semeadora-adubadora da marca Semeato, modelo PAR 2800, com quatro linhas. A plantadora estava equipada com discos de corte e com um sistema para sulcagem e distribuição do adubo e disco duplo desencontrado para sulcagem e distribuição das sementes. O sistema dosador de sementes era o de discos perfurados horizontais 
adaptado ao tamanho da semente.

Tabela 20: Critérios para diferentes níveis de fertilização

\begin{tabular}{|c|c|c|c|c|c|c|}
\hline $\begin{array}{c}\text { Cultura } \\
\text { Produção esperada }\end{array}$ & & $\mathrm{N}^{\mathrm{T}}$ & $\mathrm{N}^{2}$ & $\mathrm{P}_{2} \mathrm{O}_{5}^{3}$ & $\mathrm{~K}_{2} \mathrm{O}^{4}$ & FTE BR-12 \\
\hline Milho & $\mathrm{T}$ & 30 & $30+90$ & 0 & 0 & 30 \\
\hline $9 \mathrm{t} / \mathrm{ha}^{5}$ & $\mathrm{EG}$ & 30 & $30+90$ & 83 & 55 & 30 \\
\hline
\end{tabular}

Tabela 21: Niveis de fertilização

\begin{tabular}{lll}
\hline $\mathrm{kg}$ de adubo & $\mathrm{T}$ & $\mathrm{EG}$ \\
\hline Uréia & 67 & 67 \\
Super fosfato simples & -- & 415 \\
KCl & -- & 92 \\
BR-12 & 30 & 30 \\
Sulfato de amônia & 572 & 572 \\
\hline
\end{tabular}

As tabelas 20 e 21 apresentam, respectivamente, os critérios que determinaram os níveis de fertilização de cada sistema e a quantidade e tipo de fertilizante utilizado para a adubação segundo o rendimento esperado (EG) e adubação sem aplicação de fósforo e potássio (T).

O controle da mato-competição foi feito com pulverização química com atrazina; a dose utilizada foi de 4 litros por hectare para grade e 2 litros por hectare para o plantio direto.

Como pode-se observar na tabela 22 , o tempo de ocupação do preparo à colheita foi de 134 dias; da semeadura à colheita, 112 dias e da emergência à colheita, 108 dias. A tabela 22 apresenta, resumidamente, os principais eventos ocorridos nos sistemas de produção avaliados. 
Tabela 22: Cronograma das atividades

\begin{tabular}{lll}
\hline Evento & Data & Observação \\
\hline Preparo do solo & $09 / 09 / 96$ & Grade + Atrazina (21) p/GA \\
Dessecação das plantas daninhas & $26 / 10 / 96$ & Round up (21/ha) p/ PD \\
Adubação e Semeadura & $31 / 10 / 96$ & \\
Controle de plantas daninhas & $03 / 12 / 96$ & Atrazina (21) p/ GA \\
& $26 / 12 / 96$ & Atrazina (21) p/ PD e GA \\
Cobertura nitrogenada & $21 / 11 / 96$ & $1^{2}$ cobertura \\
& $17 / 12 / 96$ & $2^{2}$ cobertura \\
Controle fitossanitário & & Lorsban e Karatê para GA e PD \\
Colheita e trilha & $20 / 02 / 97$ & \\
\hline
\end{tabular}

A radiação incidente para o cálculo da eficiência fotossintética, considerou, segundo a sugestão deste método o período compreendido entre o preparo de solo e a colheita.

Tabela 23: Radiação incidente

\begin{tabular}{lcc}
\hline & \multicolumn{3}{c}{ RADIAÇ̃̃O SOLAR MEDIA DIÁRIA } \\
\hline OUTUBRO & cal/cm.cm & Mcal/ha \\
NOVEMBRO & 229,8 & 22980 \\
DEZEMBRO & 228,59 & 22859 \\
JANEIRO & 198,15 & 19815 \\
Média & 214,11 & 21411 \\
\hline
\end{tabular}

O valor utilizado para a análise econômica foi o preço mínimo da saca de milho que é de $R \$ 7,14$. O preço da terra considerado para a análise "SER" foi de US\$ 840,00 , válido para o estado de Goiás, para áreas aráveis, no ano de 1997-98 (Agrianual 1998), e a taxa de juros de $30 \%$ ao ano. 


\section{RESULTADOS}

A tabela 24 apresenta os resultados de cada sistema quanto à produtividade por hectare, os quais fundamentaram todos os índices, de segurança alimentar, produtividade energética e rentabilidade líquida dos sistemas.

Tabela 24: Produtividade por sistema

\begin{tabular}{lc}
\hline & Produção Média \\
\cline { 2 - 2 } & $\mathrm{kg} /$ hectare \\
\hline Plantio Direto Adubação T & 5893,25 \\
Plantio Direto Adubação EG & 5928 \\
Grade Aradora Adubação T & 5729,25 \\
Grade Aradora Adubação EG & 5823,25 \\
\hline
\end{tabular}

As tabelas 25, 26, 27 e 28 apresentam as planilhas econômicas para os sistemas de produção GAEG, PDEG, GAT e PDT, respectivamente. Estes resultados fundamentam a elaboração dos índices de rentabilidade dos sistemas.

As tabelas $29,30,31$ e 32 apresentam as planilhas energéticas para os sistemas de produção GAEG, PDEG, GAT e PDT, respectivamente. Estes resultados fundamentam a elaboração dos índices de energia dos sistemas.

As tabelas 33, 34, 35 e 36 apresentam as análises "SER" para os sistemas de produção GAEG, PDEG, GAT e PDT, respectivamente. Estes são os resultados finais obtidos pela metodologia e que permitem a aferição da sustentabilidade dos sistemas segundo a metodologia proposta.. 
Tabela 25: Custo de produção do sistema com gradagem e adubação EG

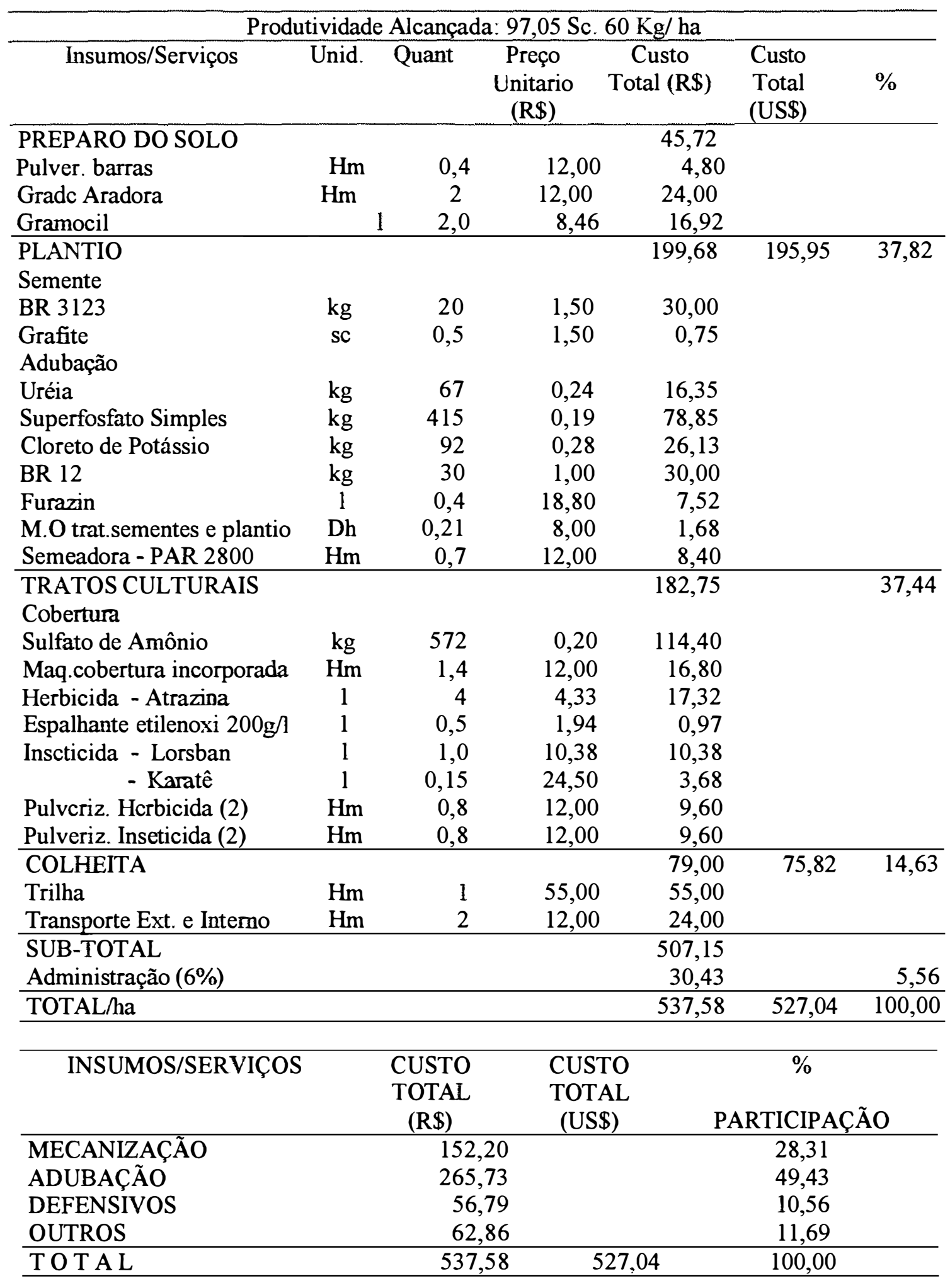


Tabela 26: Custo de produção do sistema com plantio direto e adubação EG

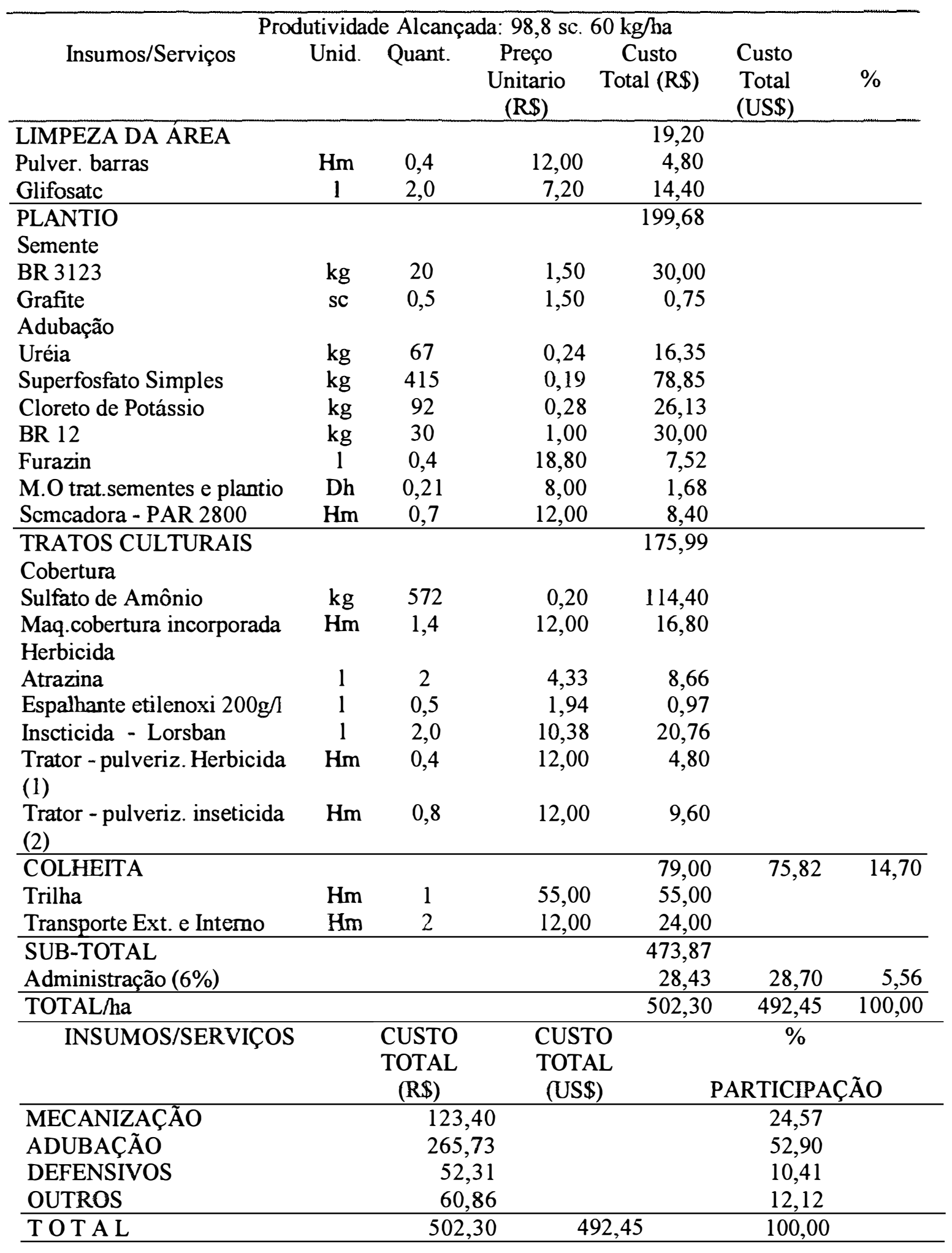


Tabela 27: Custo de produção do sistema com Gradagem e adubação T

\begin{tabular}{|c|c|c|c|c|c|c|}
\hline Proc & utivida & de Alcanç & dda: $95,5 \mathrm{sc}$. & $60 \mathrm{~kg} / \mathrm{ha}$ & & \\
\hline Insumos/Serviços & Unid. & Quant & $\begin{array}{l}\text { Preço } \\
\text { Unitario } \\
\text { (R\$) }\end{array}$ & $\begin{array}{c}\text { Custo } \\
\text { Total (R\$) }\end{array}$ & $\begin{array}{l}\text { Custo } \\
\text { Total } \\
\text { (US\$) }\end{array}$ & $\%$ \\
\hline PREPARO DO SOLO & & & & 45,72 & & \\
\hline Pulver. barras & $\mathrm{Hm}$ & 0,4 & 12,00 & 4,80 & & \\
\hline Gramocil & 1 & 2,0 & 8,46 & 16,92 & & \\
\hline Grade Aradora & $\mathrm{Hm}$ & 2 & 12,00 & 24,00 & & \\
\hline PLANTIO & & & & 94,70 & 92,93 & 22,23 \\
\hline Semente & & & & & & \\
\hline BR 3123 & $\mathrm{~kg}$ & 20 & 1,50 & 30,00 & & \\
\hline Grafite & sc & 0,5 & 1,50 & 0,75 & & \\
\hline Adubação & & & & & & \\
\hline Uréia & $\mathrm{kg}$ & 67 & 0,24 & 16,35 & & \\
\hline BR 12 & $\mathrm{~kg}$ & 30 & 1,00 & 30,00 & & \\
\hline Furazin & 1 & 0,4 & 18,80 & 7,52 & & \\
\hline M.O trat.sementes e plantio & $\mathrm{Dh}$ & 0,21 & 8,00 & 1,68 & & \\
\hline Scmcadora - PAR 2800 & $\mathrm{Hm}$ & 0,7 & 12,00 & 8,40 & & \\
\hline TRATOS CULTURAIS & & & & 182,75 & 202,51 & 48,44 \\
\hline Cobertura & & & & & & \\
\hline Sulfato de Amônio & $\mathrm{kg}$ & 572 & 0,20 & 114,40 & & \\
\hline Maq.cobertura incorporada & $\mathrm{Hm}$ & 1,4 & 12,00 & 16,80 & & \\
\hline Herbic & 1 & 4 & 4,33 & 17,32 & & \\
\hline Espalhante Etilenoxi 200 & 1 & 0,5 & 1,94 & 0,97 & & \\
\hline $\mathrm{g} / \mathrm{l}$ & & & & & & \\
\hline Inseticida - Lorsban & 1 & 1,0 & 10,38 & 10,38 & & \\
\hline - Kara & 1 & 0,15 & 24,50 & 3,68 & & \\
\hline Pulveriz. inseticida (2) & $\mathrm{Hm}$ & 0,8 & 12,00 & 9,60 & & \\
\hline Pulveriz. Herbicida (2) & $\mathrm{Hm}$ & 1,2 & 12,00 & 9,60 & & \\
\hline COLHEITA & & & & 79,00 & 75,82 & 18,13 \\
\hline Trilha & $\mathrm{Hm}$ & 1 & 55,00 & 55,00 & & \\
\hline Transporte Ext e Interno & $\mathrm{Hm}$ & 2 & 12,00 & 24,00 & & \\
\hline SUB-TOTAL & & & & 402,17 & & \\
\hline Administração (6\%) & & & & 24,13 & 23,28 & 5,57 \\
\hline TOTAL/ha & & & & 426,30 & 417,94 & 100,00 \\
\hline INSUMOS/SERVIÇOS & & CUSTO & CUS1 & & $\%$ & \\
\hline & & TOTAL & TOTA & & & \\
\hline & & $(\mathrm{R} \$)$ & (USS & & ARTICIPA & \\
\hline MECANIZAÇÃO & & 152 & & & 35,70 & \\
\hline ADUBAÇÃO & & 160 & & & 37,71 & \\
\hline DEFENSIVOS & & & & & 13,32 & \\
\hline OUTROS & & & & & 13,27 & \\
\hline TOTAL & & 426 & & 17,94 & 100,00 & \\
\hline
\end{tabular}


Tabela 28: Custo de produção do sistema com plantio direto e adubação T

\begin{tabular}{|c|c|c|c|c|c|c|}
\hline \multicolumn{7}{|c|}{ Produtividade Alcançada: $97,8 \mathrm{sc} .60 \mathrm{Kg} / \mathrm{ha}$} \\
\hline Insumos/Serviços & Unid. & Quant & $\begin{array}{l}\text { la: } 97,8 \text { sc. } 60 \\
\text { Preço } \\
\text { Unitario } \\
(\mathrm{R} \$)\end{array}$ & $\begin{array}{c}\text { Custo } \\
\text { Total (R\$) }\end{array}$ & $\begin{array}{c}\text { Custo } \\
\text { Total } \\
\text { (US\$) }\end{array}$ & $\%$ \\
\hline$\overline{\text { LIMPEZA DA ÁREA }}$ & & & & 19,20 & & \\
\hline Pulvcr. barras & $\mathrm{Hm}$ & 0,4 & 12,00 & 4,80 & & \\
\hline Glifosate & 1 & 2 & 7,20 & 14,40 & & \\
\hline PLANTIO & & & & 94,70 & 92,93 & 22,35 \\
\hline \multicolumn{7}{|l|}{ Semente } \\
\hline BR 3123 & $\mathrm{~kg}$ & 20 & 1,50 & 30,00 & & \\
\hline Grafite & sc & 0,5 & 1,50 & 0,75 & & \\
\hline \multicolumn{7}{|l|}{ Adubação } \\
\hline Uréia & $\mathrm{kg}$ & 67 & 0,24 & 16,35 & & \\
\hline BR 12 & $\mathrm{~kg}$ & 30 & 1,00 & 30,00 & & \\
\hline Furazin & 1 & 0,4 & 18,80 & 7,52 & & \\
\hline M.O trat.sementes e plantio & $\mathrm{Dh}$ & 0,21 & 8,00 & 1,68 & & \\
\hline Semeadora - PAR 2800 & $\mathrm{Hm}$ & 0,7 & 12,00 & 8,40 & & \\
\hline TRATOS CULTURAIS & & & & 175,99 & & \\
\hline \multicolumn{7}{|l|}{ Cobertura } \\
\hline Sulfato de Amônio & $\mathrm{kg}$ & 572 & 0,20 & 114,40 & & \\
\hline $\begin{array}{l}\text { Maq.cobertura incorporada } \\
\text { Herbicida - }\end{array}$ & $\mathrm{Hm}$ & 1,4 & 12,00 & 16,80 & & \\
\hline Atrazina & 1 & 2 & 4,33 & 8,66 & & \\
\hline Espalhante Etilenoxi $200 \mathrm{~g} / 1$ & 1 & 0,5 & 1,94 & 0,97 & & \\
\hline Inseticida - Lorsban & 1 & 2,0 & 10,38 & 20,76 & & \\
\hline Pulverização. Herbicida (1) & $\mathrm{Hm}$ & 0,4 & 12,00 & 4,80 & & \\
\hline Pulverização. inseticida (2) & $\mathrm{Hm}$ & 0,8 & 12,00 & 9,60 & & \\
\hline COLHEITA & & & & 79,00 & 75,82 & 18,24 \\
\hline Trilha & $\mathrm{Hm}$ & 1 & 55,00 & 55,00 & & \\
\hline Transporte Ext. e Interno & $\mathrm{Hm}$ & 2 & 12,00 & 24,00 & & \\
\hline SUB-TOTAL & & & & 368,89 & & \\
\hline Administração (6\%) & & & & 22,13 & & 5,57 \\
\hline TOTAL/ha & & & & 391,02 & 383,35 & 100,00 \\
\hline \multirow[t]{2}{*}{ INSUMOS/SERVIÇOS } & & CUSTO & & \multicolumn{2}{|l|}{$\%$} \\
\hline & & $\begin{array}{l}\text { TOTAL } \\
\text { (R\$) }\end{array}$ & $\begin{array}{r}\text { TOTAI } \\
\text { (US\$) }\end{array}$ & & \multicolumn{2}{|c|}{ PARTICIPACCÃO } \\
\hline MECANIZAÇÁ̆O & \multicolumn{3}{|c|}{123,40} & & \multicolumn{2}{|l|}{31,56} \\
\hline ADUBACุÃO & \multirow{2}{*}{\multicolumn{3}{|c|}{$\begin{array}{r}160,75 \\
52,31\end{array}$}} & & \multicolumn{2}{|l|}{41,11} \\
\hline DEFENSIVOS & \multirow{2}{*}{\multicolumn{3}{|c|}{$\begin{array}{l}52,31 \\
54,56\end{array}$}} & & \multirow{2}{*}{\multicolumn{2}{|c|}{19,27}} \\
\hline OUTROS & & & & & & \\
\hline TOTAL & \multicolumn{3}{|c|}{390,02} & 33,25 & \multicolumn{2}{|l|}{100,00} \\
\hline
\end{tabular}


Tabela 29: Análise energética do sistema com Gradagem e adubação EG

\begin{tabular}{|c|c|c|c|c|}
\hline \multicolumn{5}{|c|}{ ANÁLISE ENERGÉTICA } \\
\hline CULTURA & milho & PRODUÇÃO & 5823,25 & \\
\hline MANEJO & Grade & $\mathrm{kcal} / \mathrm{kg}$ & 3610 & \\
\hline ADUBAÇÃO & EG & Energia & 21021932,5 & \\
\hline \multirow[t]{2}{*}{ Insumos/Serviços } & Unidade & Quantidade & Custo Energético & Total \\
\hline & & & \multicolumn{2}{|c|}{ dados em kcal } \\
\hline Gradagem & ha & 2 & 47975,5 & $\overline{95951}$ \\
\hline Semente & $\mathrm{kg}$ & 20 & 7220 & 144400 \\
\hline Grafite & $\mathrm{kg}$ & 0,5 & 7800 & 3900 \\
\hline Uréia & $\mathrm{kg}$ & 67 & 18643 & 1249081 \\
\hline SPS & $\mathrm{kg}$ & 415 & 2340 & 971100 \\
\hline $\mathrm{KCl}$ & $\mathrm{kg}$ & 92 & 1718 & 158056 \\
\hline Micronutrientes & US\$ & 29,4 & 10141 & 298145,4 \\
\hline Furazin & 1 & 0,4 & 86910 & 34764 \\
\hline Mão de obra tratamento & h.h & 0,15 & 300 & 45 \\
\hline Semeadura & ha & 1 & 31536,5 & 31536,5 \\
\hline Sulf. De Amônio & $\mathrm{kg}$ & 572 & 5250 & 3003000 \\
\hline Adubação cob. & ha & 1 & 31536,5 & 31536,5 \\
\hline Herbicidas & 1 & 6 & 99910 & 599460 \\
\hline Espalhante & US\$ & 0,95 & 10141 & 9633,95 \\
\hline Inseticidas & 1 & 1,15 & 86910 & 99946,5 \\
\hline Pulverização & ha & 5 & 10035 & 50175 \\
\hline Colheita & ha & 1 & 168463 & 168463 \\
\hline Transporte & $\mathrm{km} . \mathrm{t}$ & & & 0 \\
\hline$\overline{\text { Total }}$ & & & \multicolumn{2}{|r|}{6949193,85} \\
\hline Balanço O/I & & & \multicolumn{2}{|r|}{3,03} \\
\hline Produtividade cultural & & & \multicolumn{2}{|r|}{0,84} \\
\hline & Total & $\%$ \\
\hline Mecanização & & & 209199 & 3,01 \\
\hline Adubos & & & 5679382,4 & 81,73 \\
\hline Defensivos & & & 743804,45 & 10,70 \\
\hline
\end{tabular}


Tabela 30: Análise energética do sistema com plantio direto e adubação EG

\begin{tabular}{|c|c|c|c|c|}
\hline \multicolumn{5}{|c|}{ ANÁLISE ENERGÉTICA } \\
\hline CULTURA & milho & PRODUÇÃO & 5928 & \\
\hline MANEJO & PD & $\mathrm{kcal} / \mathrm{kg}$ & 3610 & \\
\hline ADUBAÇÃO & EG & Energia & 21400080 & \\
\hline \multirow[t]{2}{*}{ Insumos/Serviços } & Unidade & Quantidade & Custo Energético & Total \\
\hline & & & \multicolumn{2}{|c|}{ dados em kcal } \\
\hline Semente & $\mathrm{kg}$ & 20 & 7220 & 144400 \\
\hline Grafite & $\mathrm{kg}$ & 0,5 & 7800 & 3900 \\
\hline Uréia & $\mathrm{kg}$ & 67 & 18643 & 1249081 \\
\hline SPS & $\mathrm{kg}$ & 415 & 2340 & 971100 \\
\hline $\mathrm{KCl}$ & $\mathrm{kg}$ & 92 & 1718 & 158056 \\
\hline Micronutrientes & US\$ & 29,4 & 10141 & 298145,4 \\
\hline Furazin & 1 & 0,4 & 86910 & 34764 \\
\hline Mão de obra tratamento & h.h & 0,15 & 300 & 45 \\
\hline Semeadura & ha & 1 & 31536,5 & 31536,5 \\
\hline Sulf. De Amônio & $\mathrm{kg}$ & 572 & 5250 & 3003000 \\
\hline Adubação cob. & ha & 1 & 31536,5 & 31536,5 \\
\hline Herbicidas & 1 & 4 & 99910 & 399640 \\
\hline Espalhante & US\$ & 0,95 & 10141 & 9633,95 \\
\hline Inseticidas & 1 & 2 & 86910 & 173820 \\
\hline Pulverização & ha & 4 & 10035 & 40140 \\
\hline Colheita & ha & 1 & 168463 & 168463 \\
\hline Transporte & $\mathrm{km} \cdot \mathrm{t}$ & & & 0 \\
\hline Total & & & & 6717261,35 \\
\hline Balanço O/I & & & & 3,19 \\
\hline \multirow[t]{2}{*}{ Produtividade cultural } & & & & 0,88 \\
\hline & & & Total & $\%$ \\
\hline Mecanização & & & 103213 & 1,54 \\
\hline Adubos & & & 5679382,4 & 84,55 \\
\hline Defensivos & & & 617857,95 & 9,20 \\
\hline
\end{tabular}


Tabela 31: Análise energética do sistema com Gradagem e adubação T

\begin{tabular}{|c|c|c|c|c|}
\hline \multicolumn{5}{|c|}{ ANÁLISE ENERGÉTICA } \\
\hline CULTURA & milho & PRODUÇÃO & 5729,25 & \\
\hline MANEJO & Grade & $\mathrm{kcal} / \mathrm{kg}$ & 3610 & \\
\hline ADUBAÇÃO & $\mathrm{T}$ & Energia & 20682592,5 & \\
\hline \multirow[t]{2}{*}{ Insumos/Serviços } & Unidade & Quantidade & Custo Energético & Total \\
\hline & & & \multicolumn{2}{|c|}{ dados em kcal } \\
\hline Gradagem & ha & 2 & 47975,5 & 95951 \\
\hline Semente & $\mathrm{kg}$ & 20 & 7220 & 144400 \\
\hline Grafite & $\mathrm{kg}$ & 0,5 & 7800 & 3900 \\
\hline Uréia & $\mathrm{kg}$ & 67 & 18643 & 1249081 \\
\hline Micronutrientes & US\$ & 29,4 & 10141 & 298145,4 \\
\hline Furazin & 1 & 0,4 & 86910 & 34764 \\
\hline M.0. trat./plantio & h.h & 0,15 & 300 & 45 \\
\hline Semeadura & ha & 1 & 31536,5 & 31536,5 \\
\hline Sulf. De Amônio & $\mathrm{kg}$ & 572 & 5250 & 3003000 \\
\hline Adubação cob. & ha & 1 & 31536,5 & 31536,5 \\
\hline Herbicidas & 1 & 6 & 99910 & 599460 \\
\hline Espalhante & US\$ & 0,95 & 10141 & 9633,95 \\
\hline Inseticidas & 1 & 1,15 & 86910 & 99946,5 \\
\hline Pulverização & ha & 5 & 10035 & 50175 \\
\hline Colheita & ha & 1 & 168463 & 168463 \\
\hline Transporte & $\mathrm{km} . \mathrm{t}$ & & & 0 \\
\hline Total & & & & 5820037,85 \\
\hline Balanço O/I & & & & 3,55 \\
\hline \multirow{2}{*}{\multicolumn{2}{|c|}{ Produtividade cultural }} & & & 0,98 \\
\hline & & & Total & $\%$ \\
\hline Mecanização & & & 377662 & 6,49 \\
\hline Adubos & & & 4252081 & 73,06 \\
\hline Defensivos & & & 743804,45 & 12,78 \\
\hline
\end{tabular}


Tabela 32: Análise energética do sistema com plantio direto e adubação T

\begin{tabular}{|c|c|c|c|c|}
\hline \multicolumn{5}{|c|}{ ANÁLISE ENERGÉTICA } \\
\hline CULTURA & milho & PRODUÇÃO & 5893,25 & \\
\hline MANEJO & PD & $\mathrm{kcal} / \mathrm{kg}$ & 3610 & \\
\hline ADUBAÇÃO & $\mathrm{T}$ & Energia & 21274632,5 & \\
\hline \multirow[t]{2}{*}{ Insumos/Serviços } & Unidade & Quantidade & Custo Energético & Total \\
\hline & & & \multicolumn{2}{|c|}{ dados em kcal } \\
\hline Semente & $\mathrm{kg}$ & 20 & 7220 & 144400 \\
\hline Grafite & $\mathrm{kg}$ & 0,5 & 7800 & 3900 \\
\hline Uréia & $\mathrm{kg}$ & 67 & 18643 & 1249081 \\
\hline Micronutrientes & US\$ & 29,4 & 10141 & 298145,4 \\
\hline Furazin & 1 & 0,4 & 86910 & 34764 \\
\hline M.O. trat./plantio & h.h & 0,15 & 300 & 45 \\
\hline Semeadura & ha & 1 & 31563,5 & 31563,5 \\
\hline Sulf. De Amônio & $\mathrm{kg}$ & 572 & 5250 & 3003000 \\
\hline Adubação cob. & ha & 1 & 31536,5 & 31536,5 \\
\hline Herbicidas & 1 & 4 & 99910 & 399640 \\
\hline Espalhante & US\$ & 0,95 & 10141 & 9633,95 \\
\hline Inseticidas & 1 & 2 & 86910 & 173820 \\
\hline Pulverização & ha & 4 & 10035 & 40140 \\
\hline Colheita & ha & 1 & 168463 & 168463 \\
\hline Transporte & $\mathrm{km} \cdot \mathrm{t}$ & & & 0 \\
\hline Total & & & & 5588132,35 \\
\hline Balanço O/I & & & & 3,81 \\
\hline Produtividade cultural & & & & 1,05 \\
\hline & & & Total & $\%$ \\
\hline Mecanização & & & 271703 & 4,86 \\
\hline Adubação & & & 4252081 & 76,09 \\
\hline Defensivos & & & 617857,95 & 11,06 \\
\hline
\end{tabular}


Tabela 33: Análise do método "SER" para a avaliação do sistema com Gradagem e adubação EG

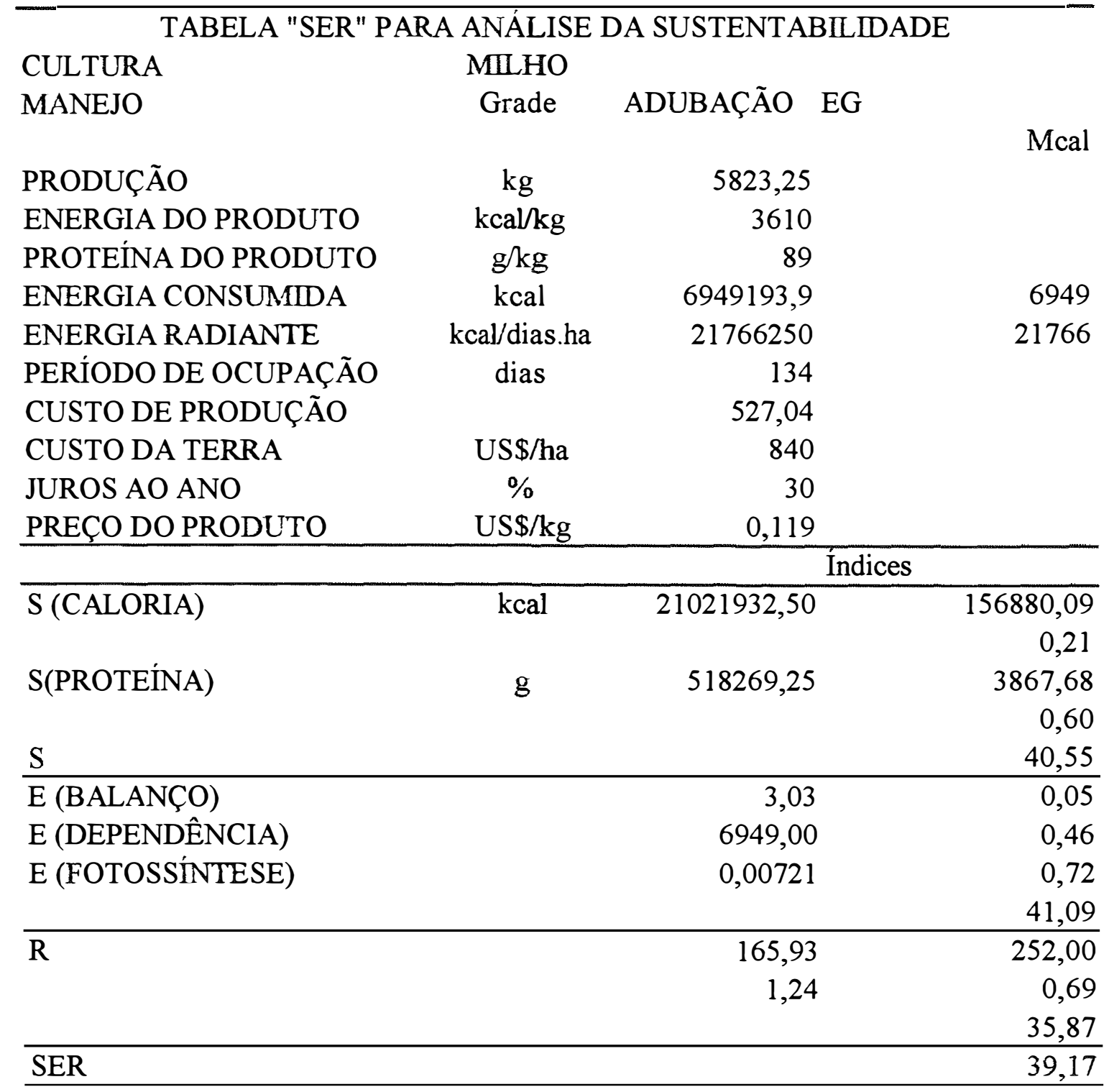


Tabela 34: Análise do método "SER" para a avaliação do sistema com Plantio direto e adubação EG

\begin{tabular}{|c|c|c|c|}
\hline \multicolumn{4}{|c|}{ TABELA "SER" PARA ANÁLISE DA SUSTENTABILIDADE } \\
\hline CULTURA & MILHO & & \\
\hline \multirow[t]{2}{*}{ MANEJO } & PD & ADUBAÇÃO EG & \\
\hline & & & Mcal \\
\hline PRODUÇÃO & $\mathrm{kg}$ & 5928 & \\
\hline ENERGIA DO PRODUTO & $\mathrm{kcal} / \mathrm{kg}$ & 3610 & \\
\hline PROTEÍNA DO PRODUTO & $\mathrm{g} / \mathrm{kg}$ & 89 & \\
\hline ENERGIA CONSUMIDA & kcal & 6717261,35 & 6717 \\
\hline ENERGIA RADIANTE & $\mathrm{kcal} /$ dia.ha & 21766250 & 21766 \\
\hline PERÍODO DE OCUPAÇÃO & dias & 134 & \\
\hline CUSTO DE PRODUÇÃO & US\$ & 492,45 & \\
\hline CUSTO DA TERRA & US\$/ha & 840 & \\
\hline JUROS AO ANO & $\%$ & 30 & \\
\hline \multirow[t]{2}{*}{ PREÇO DO PRODUTO } & US $\$ / \mathrm{kg}$ & 0,119 & \\
\hline & & \multicolumn{2}{|c|}{ Índices } \\
\hline \multirow[t]{2}{*}{ S (CALORIA) } & kcal & 21400080 & 159702,09 \\
\hline & & & 0,22 \\
\hline \multirow[t]{2}{*}{ S(PROTEÍNA) } & $\mathrm{g}$ & 527592 & 3937,25 \\
\hline & & & 0,61 \\
\hline $\mathrm{S}$ & & & 41,28 \\
\hline$\overline{\text { E (BALANÇO) }}$ & & 3,19 & 0,05 \\
\hline E (DEPENDÊNCIA) & & 6717 & 0,47 \\
\hline \multirow[t]{2}{*}{ E (FOTOSSÍNTESE) } & & 0,0073 & 0,73 \\
\hline & & & 41,81 \\
\hline \multirow[t]{3}{*}{$\mathrm{R}$} & & 212,98 & 252,00 \\
\hline & & 1,59 & 0,69 \\
\hline & & & 46,04 \\
\hline SER & & & 43,05 \\
\hline
\end{tabular}


Tabela 35: Análise do método "SER" para a avaliação do sistema com Gradagem e adubação T

\begin{tabular}{|c|c|c|c|}
\hline \multicolumn{4}{|c|}{ TABELA "SER" PARA ANÁLISE DA SUSTENTABILIDADE } \\
\hline CULTURA & MILHO & & \\
\hline \multirow[t]{2}{*}{ MANEJO } & Grade & ADUBAÇÃO T & \\
\hline & & & Mcal \\
\hline PRODUÇÃO & $\mathrm{kg}$ & 5729,25 & \\
\hline ENERGIA DO PRODUTO & $\mathrm{kcal} / \mathrm{kg}$ & 3610 & \\
\hline PROTEÍNA DO PRODUTO & $\mathrm{g} / \mathrm{kg}$ & 89 & \\
\hline ENERGIA CONSUMIDA & $\mathrm{kcal}$ & 5820037,9 & 5820 \\
\hline ENERGIA RADIANTE & $\mathrm{kcal} / \mathrm{dia} \cdot \mathrm{ha}$ & 21766250 & 21766 \\
\hline PERÍODO DE OCUPAÇÃO & dias & 134 & \\
\hline CUSTO DE PRODUÇÃO & US\$ & 417,94 & \\
\hline CUSTO DA TERRA & US\$/ha & 840 & \\
\hline JUROS AO ANO & $\%$ & 30 & \\
\hline \multirow[t]{2}{*}{ PREÇO DO PRODUTO } & US\$/kg & 0,119 & \\
\hline & & \multicolumn{2}{|c|}{ Indices } \\
\hline \multirow[t]{2}{*}{ S (CALORIA) } & $\mathrm{kcal}$ & 20682592,5 & 154347,71 \\
\hline & & & 0,21 \\
\hline \multirow[t]{2}{*}{ S(PROTEÍNA) } & g & 509903,25 & 3805,25 \\
\hline & & & 0,59 \\
\hline $\mathrm{S}$ & & & 39,90 \\
\hline$\overline{\text { E (BALANÇO) }}$ & & 3,55 & $\overline{0,06}$ \\
\hline E (DEPENDÊNCIA) & & 5820 & 0,49 \\
\hline \multirow[t]{2}{*}{ E (FOTOSSÍNTESE) } & & 0,0071 & 0,71 \\
\hline & & & 42,07 \\
\hline \multirow[t]{3}{*}{$\mathrm{R}$} & & 263,84 & 252,00 \\
\hline & & 1,969 & 0,69 \\
\hline & & & 57,04 \\
\hline SER & & & 46,34 \\
\hline
\end{tabular}


Tabela 36: Análise do método "SER" para a avaliação do sistema com Plantio direto e adubação $\mathrm{T}$

\begin{tabular}{|c|c|c|c|}
\hline \multicolumn{4}{|c|}{ TABELA "SER" PARA ANÁLISE DA SUSTENTABILIDADE } \\
\hline CULTURA & MILHO & & \\
\hline \multirow[t]{2}{*}{ MANEJO } & PD & ADUBAÇÃO T & \\
\hline & & & Mcal \\
\hline PRODUÇÃO & $\mathrm{kg}$ & 5893,25 & \\
\hline ENERGIA DO PRODUTO & $\mathrm{kcal} / \mathrm{kg}$ & 3610 & \\
\hline PROTEÍNA DO PRODUTO & $\mathrm{g} / \mathrm{kg}$ & 89 & \\
\hline ENERGIA CONSUMIDA & $\mathrm{kcal}$ & 5588132,35 & 5588 \\
\hline ENERGIA RADIANTE & $\mathrm{kcal} / \mathrm{dia} \cdot \mathrm{ha}$ & 21766250 & 21766 \\
\hline PERÍODO DE OCUPAÇÃO & dias & 134 & \\
\hline CUSTO DE PRODUÇÃO & US\$ & 383,35 & \\
\hline CUSTO DA TERRA & US\$/ha & 840 & \\
\hline JUROS AO ANO & $\%$ & 30 & \\
\hline \multirow[t]{2}{*}{ PREÇO DO PRODUTO } & US\$/kg & 0,119 & \\
\hline & & & Índices \\
\hline \multirow[t]{2}{*}{$\overline{S \text { (C.ALORIA) }}$} & kcal & 21274632,5 & 158765,91 \\
\hline & & & 0,21 \\
\hline \multirow[t]{2}{*}{ S(PROTEÍNA) } & $\mathrm{g}$ & 524499,25 & 3914,17 \\
\hline & & & 0,61 \\
\hline$\underline{S}$ & & & 41,04 \\
\hline E (BALANÇO) & & 3,81 & 0,06 \\
\hline E (DEPENDÊNCIA) & & 5588,00 & 0,50 \\
\hline \multirow[t]{2}{*}{ E (FOTOSSÍNTESE) } & & 0,00729 & 0,73 \\
\hline & & & 43,14 \\
\hline \multirow[t]{3}{*}{$\overline{\mathrm{R}}$} & & 317,95 & 252,00 \\
\hline & & 2,37 & 0,69 \\
\hline & & & 68,73 \\
\hline SER & & & 50,97 \\
\hline
\end{tabular}


Tabela 37-: Resumo das tabelas "SER"

\begin{tabular}{cccccccccc}
\hline \multicolumn{10}{c}{ RESUMO DOS RESULTADOS DAS TABELAS "SER" } \\
\hline & $\mathrm{S}$ & $\%$ & $\mathrm{E}$ & $\%$ & $\mathrm{R}$ & $\%$ & SER & $\%$ \\
\hline SISTEMA & & & & & & & & \\
GAEG & 40,55 & 99,65 & 41,09 & 97,77 & 35,87 & 69,09 & 39,17 & 87,27 \\
PDEG & 41,28 & 101,44 & 41,81 & 99,48 & 46,04 & 88,67 & 43,05 & 95,92 \\
GAT & 39,90 & 98,05 & 42,07 & 100,10 & 57,04 & 109,86 & 46,34 & 103,25 \\
PDT & 41,04 & 100,85 & 43,14 & 102,65 & 68,73 & 132,38 & 50,97 & 113,56 \\
MÉDIA & 40,69 & & 42,03 & & 51,92 & & 44,88 & \\
\hline
\end{tabular}

Os resultados e valores apresentados nas tabelas 24 a 37 são discutidos no item seguinte. A análise destes sistemas de produção, segundo a metodologia proposta, é uma maneira de demonstrar o potencial de uso desse método por técnicos, agricultores e demais profissionais ligados ao setor agrícola. 


\section{DISCUSSÕES}

\subsection{Sustentabilidade na agricultura}

Pode-se observar que as diversas manifestações em torno da expressão sustentabilidade evidenciam uma mudança de pensamento, apoiada pela necessidade urgente de repensar a produção agrícola. No entanto, a noção de agricultura sustentável permanece cercada de imprecisões, permitindo englobar desde aqueles que se contentam com simples ajustes no atual padrão produtivo, até aqueles que vêem nessa noção um objetivo de longo prazo que possibilite mudanças estruturais, não só na produção mas também em toda a sociedade.

Pode-se concluir que a sustentabilidade na agricultura, ou a sustentabilidade como conceito, não saiu do plano das idéias. Existem vários parâmetros que são considerados como bases para a sustentabilidade, que foram discutidos neste trabalho.

Existem políticas públicas já sugeridas para a promoção da sustentabilidade na agricultura, não podem, e não devem, entretanto ser implementadas sem uma ampla discussão na sociedade e junto aos setores rurais. A segurança alimentar está em jogo, não se pode modificar drásticamente os atuais sistemas de produção sem correr o risco de comprometer o abastecimento de alimentos à população. Ao mesmo tempo a necessidade de se promover grandes mudanças nos sistemas parece clara para a maior parte dos técnicos do setor.

No entanto, a noção de agricultura sustentável permanece cercada de incertezas, permitindo incluir desde aqueles que se contentam com algumas poucas mudanças no atual padrão produtivo, até aqueles que vêem nesse conceito um objetivo de longo prazo que implique mudanças estruturais, não só na produção mas também em toda a sociedade. No momento, todos parecem concordar que a agricultura sustentável é ainda 
um anseio; o que varia, é a expectativa em relação ao grau das mudanças contidas nesse objetivo, os parâmetros que a envolvem e, consequentemente, seu prazo de estabelecimento.

Os sistemas agrícolas que foram construídos ao longo das últimas décadas contribuíram grandemente para aliviar a fome e elevar os padrões de vida. Até certo ponto, cumpriram seus objetivos. Mas as novas realidades revelam as contradições inerentes a estes sistemas. Elas requerem sistemas agrícolas que dediquem atenção tanto às pessoas como às tecnologias, tanto aos recursos naturais como à produção, tanto ao longo quanto ao curto prazo.

Em virtude das várias situações em que os diferentes sistemas de produção se encontram, não há um consenso quanto às características inerentes à sustentabilidade. Pode-se constatar que a sustentabilidade na agricultura, ou a sustentabilidade como conceito, não saiu do plano das idéias. Existem vários parâmetros que são considerados como bases para a sustentabilidade e que foram discutidos na revisão da literatura.

Dentre os diversos autores que citam fatores que determinam a sustentabilidade, ou a insustentabilidade de um sistema de produção, ou agroecossistema, depreende-se, que um sistema deve ter: a) Retorno financeiro adequado para os agricultores; b) Manutenção da capacidade produtiva; c) Minimização de impactos adversos sobre o meio ambiente; d) Manutenção da homeostase e da capacidade evolutiva; e) Manutenção da disponibilidade dos recursos naturais como terra e água; f) Preservação da biodiversidade; g) Minimização do uso de insumos; h) Satisfação das necessidade humanas de alimentação; i) Otimização da reciclagem de nutrientes; j) Preservação do saber local; k) Redução de perdas por pragas e doenças; 1) Desenvolvimento participativo de tecnologias e m) Manejo dos fluxos de radiação solar, água e ar.

Quão importantes, ou quanto essas bases contribuem para a sustentabilidade dos processos permanece uma incógnita, são assim linhas gerais da construção da agricultura sustentável. A subjetividade, ou pouca clareza, dos fatores e modificações que o objetivo da sustentabilidade implicam é um obstáculo intransponível para que se possa traçar metas e orientar as mudanças rumo à mesma. 


\subsection{O método "SER"}

A metodologia "SER" é uma ferramenta de diagnóstico, entretanto, ferramentas não são úteis por si só, necessitam pessoas que queiram e saibam utilizá-las. Existem dois caminhos claros para reformular os sistemas agrícolas vigentes, as políticas públicas e a sensibilização e orientação ao agricultor. Legisladores e extensionistas, pela importância capital dos temas pelos quais são responsáveis, não podem prescindir, sob qualquer hipótese, do embasamento técnico e da participação da sociedade, em seu todo, mas principalmente do homem e da mulher do campo. Certamente, os indicadores econômicos não respondem adequadamente às questões acerca da capacidade de suporte de um sistema biofisico, visto que este sistema possui fatores que não podem ser adequadamente valorados economicamente.

A ação do técnico extensionista que já orientou a agricultura e o agricultor para uma visão fragmentada do sistema agrícola pode contribuir para a construção da visão sistêmica. $\mathrm{O}$ método é baseado na análise de sistemas produtivos como um todo, não se prende à produtividade ou rentabilidade do sistema, propõe uma interligação do manejo da propriedade com o planeta e seus recursos, indica problemas relacionados à sustentabilidade do sistema de produção. Todas essas características do método aqui proposto podem ser exploradas pelo técnico extensionista para estimular o agricultor a assumir novas posturas e paradigmas na sua maneira de ver e fazer agricultura.

A estrutura deste método de avaliação para sistemas de produção é basicamente norteada pelos aspectos essenciais à sustentabilidade de acordo com as visões, apresentadas na revisão, de cientistas, agricultores e outros públicos interessados na questão. Segurança alimentar é apenas o aspecto mais emergencial da função social da agricultura, é a visão restrita à demanda da sociedade, cada vez mais urbana. Inúmeros outros fatores podem afetar a sustentabilidade social dos agroecossistemas, como a adaptabilidade das tecnologias, a qualidade de vida das pessoas envolvidas com o processo agrícola, a justiça social no campo, a distribuição de terras, a perspectiva de continuidade da atividade pelas futuras gerações e a preservação do saber nativo. Portanto, existem fatores que não estão sendo diretamente mensurados e considerados 
no índice gerado por este método, entretanto, existem relações indiretas do resultado com estes parâmetros e fica como sugestão para continuidade dos trabalhos.

O método, entretanto, atende aquele que é o objetivo maior, a missão dada pela sociedade à agricultura, pois inclui em sua estrutura a maior parte dos fundamentos teóricos essenciais à segurança alimentar.

Mesmo que se possa avaliar, através do método o grau de sustentabilidade da agricultura, falta encontrar um caminho para que efetivamente transformem-se os procedimentos e camiminhe a sociedade rumo à sustentabilidade. Existem dois caminhos básicos, complementares, o das políticas públicas e o da educação ambiental. A utilização deste método pode contribuir para esses dois caminhos, indicando rumos para agricultores, técnicos e formuladores das políticas públicas e, tão importante quanto isto, é a promoção da reflexão holística sobre o processo agrícola por parte de quem o usa, seja técnico ou agricultor.

As características que interessam conhecer são todas aquelas que possibilitam conhecer-se aquelas que são próprias do sistema e das pessoas que o criaram e o conduzem. O que possibilita compreender o processo decisório; que possibilita transformação em um sentido positivo; que possibilita conhecer os anseios das pessoas; que possibilita conhecer o ambiente. Há a necessidade de diagnosticar-se, portanto, inúmeros fatores dentro de um sistema de produção. Tal diagnose exige uma multiplicidade de processos como entrevistas, mapas construídos coletivamente, fotos aéreas além de outros.

O índice "SER" para sustentabilidade não deve ser analisado isoladamente, os valores para Segurança Alimentar, Eficiência Energética e Rentabilidade devem ser considerados conjuntamente de modo a permitir uma avaliação dos pontos mais positivos e negativos do sistema de produção analisado.

O método "SER" é uma proposta de abordagem que têm como característica a construção contínua e a interação com os usuários do método. Quanto mais discutir-se e aplicar-se um método "multifuncional" para a análise dos sistemas de produção mais questões relacionadas ao processo agrícola poderão ser trazidas à tona e compor a estrutura da metodologia. 


\subsection{Energia e sustentabilidade}

A energia é essencial a qualquer processo. Dispêndio energético é uma condição básica para qualquer processo bio - fisico, como podemos compreender através das leis da termodinâmica. Não há atividade que ocorra sem que a entropia do sistema aumente e a energia se torne menos disponivel. Apesar da energia não poder ser criada ou destruída, formas de energia de alta disponibilidade estão cada vez mais escassas. Esta percepção implica que o sistema agrícola não só seja visto como um todo, mas também que seja entendido como parte de um todo maior.

Os valores ou custos energéticos de bens ou serviços podem ser mensurados com precisão bastante razoável.

Existem graves problemas ambientais que podem tornar insustentável a vida humana, como o efeito estufa e a poluição do ar, das águas e do solo. A otimização energética da atividade agrícola não redime o técnico ou proprietário rural desta preocupação; entretanto, em geral a emissão de gases estufa e poluição associam-se a processos ineficientes quanto ao uso da energia como pulverizações e mecanização excessivas.

Insumos que contém, ou que exigem, grandes quantidades de energia para serem produzidos, possuem nos processos que os geraram, ou mesmo no seu uso, externalidades negativas maiores que os menos intensivos em energia. Mineração, fabrico e uso de agroquímicos e queima de combustíveis fósseis associam-se a outras causas de insustentabilidade, além do aumento da entropia do sistema.

A economia trabalha parâmetros como taxas de juros, inflação, políticas de crédito, oferta e demanda produrindo assim análises totalmente circunstanciais do sistema produtivo. Análises energéticas, por sua vez, levam em consideração parâmetros biofisicos, imutáveis na natureza; a eficiência energética de um sistema de produção

permanece relativamente constante através dos anos. O profissional da área agrícola deverá ser capaz de otimizar os processos da agricultura sob as óticas, econômica e biofisica. Caso só saiba delinear sistemas observando indicadores de mercado, o próprio 
mercado se incumbirá de considerá-lo, futuramente, inútil como profissional. A agricultura deixou, aos poucos, de ser a "arte de colher o sol" para se tornar um processo de transformação de petróleo, gás natural e eletricidade em energias assimiláveis pelo organismo humano. Acompanhando esta evolução, nossa profissão deixou a arte de lado e tornou-nos formuladores de receitas. A crescente escassez de recursos e a conscientização dos problemas ambientais no mundo exige que aprendamos a trabalhar dentro da técnica, com um olho na economicidade e outro na eficiência energética.

As discussões em torno da eficiência energética dos sistemas de produção e as diversas técnicas agrícolas surgiram e cresceram a partir das crises do petróleo da década de 70, principalmente nos EUA. Neste país, em função da chamada "revolução verde", já se encontravam sistemas de produção altamente dependentes dos insumos energéticos. No Brasil, estudos sobre o tema são raros, visto que o processo de "modernização" em nossa agricultura é relativamente recente e os preços do petróleo no mercado internacional estão estabilizados nos últimos anos. Entretanto, a perspectiva da escassez de energia nos diversos setores da sociedade permanece e impele a pesquisa agrícola a desenvolver e avaliar sistemas e técnicas de produção objetivando a eficiência no uso da energia no processo agrícola.

Em relação à entropia e sua relação com a diversidade é possível afirmar que os ecossistemas são compostos de interações ecológicas extremamente intrincadas que lhes garantem a estabilidade; há uma harmonia e proporcionalidade perfeitas entre organismos produtores e consumidores de diversas ordens. A natureza tenta impor a sua ordem, que, para nossas necessidades como produtores é desordem. Define-se estabilidade como a variação da produtividade pelo tempo, relacionada à replicabilidade e previsibilidade na atividade agrícola. A perda da diversidade dos sistemas, de modo geral, conduz à sua instabilização. Deste processo, advém a necessidade de um maiores investimentos energéticos, com o objetivo de garantir a preservação do sistema, o que acarreta em uma piora da eficiência energética.

Os agroecossitemas são estabelecidos nos ambientes naturais com o objetivo de produzir um máximo de alimentos e fibras para a manutenção da sociedade. Este máximo é limitado pelas características genéticas da cultura e pelos fatores de perdas de 
produção que são, em geral, fatores naturais/biológicos. Todos eles são somente o princípio da ação da natureza no sentido de restabelecer o equilíbrio, a diversidade do ambiente; esta ação se continuada leva à formação de um ecossistema equilibrado. A organização dos agroecossistemas termina por constituir um nicho com grande quantidade de energia organizada, sobre a qual processos mais entrópicos tendem a agir.

Quanto maior o tempo de estabelecimento do sistema antrópico, quanto maior a perspectiva de produtividade e quanto mais próximo do equador estiver o agroecossistema maiores serão as dificuldades do agricultor para proteger a cultura dos fatores biológicos/naturais.

Quanto à relação entre energia e o balanço de nutrientes pode-se afirmar que a agricultura moderna não prima pela ciclagem dos nutrientes; os restos vegetais são queimados ou manejados de forma imprópria. $\mathrm{O}$ aumento da lixiviação dos nutrientes e a erosão de solos contribuem para uma perda significativa, além, é claro, da grande exportação de nutrientes através da produção. Em sistemas nos quais a lixiviação de nutrientes e a perda de solo por erosão é muito alta a necessidade de entrada de nutrientes externos é crescente. Com relação ao manejo de solos, destacamos problemas como erosão acima de sua capacidade de suporte/gênese, perda da diversidade biológica, desestruturação fisica e salinização.

A conseqüência é o desbalanço de nutrientes, exigindo reposição brutal através dos fertilizantes químicos.

Um sistema de produção equilibrado deve ter perdas mínimas de nutrientes e a relação entre entradas e saídas deve manter-se em equilíbrio ao longo dos ciclos de produção. As perdas de nutrientes devem ser compensadas pelos gerentes do sistema agrícola para que este não perca a sua produtividade; estas reposições são em geral feitas com fertilizantes minerais. $\mathrm{O}$ fabrico de fertilizantes minerais implica diversos processos, ou seja, consumo energético, degradação de energia, que podem ser mensurados e contabilizados na análise energética.

A análise energética de sistemas de produção avalia o decréscimo da disponibilidade de recursos naturais apenas na medida em que esta redução afeta diretamente o potencial de um dado sistema produtivo. Em uma análise, em anos 
consecutivos, a menor disponibilidade quantitativa ou qualitativa de água e solo refletirá nos resultados do sistema. Neste aspecto encontramos uma lacuna na capacidade da análise energética, por não ser suficiente para avaliar os impactos ambientais de um sistema de produção quando estes afetam apenas outros locais, como no caso de poluição de cursos d'água.

Todos esses efeitos reunidos acarretam a ineficiência energética dos sistemas de produção. Os investimentos necessários para a agricultura convencional têm, em geral, elevado custo energético, ou seja, sua elaboração exige o gasto de diversas formas de energia, a maioria dessas, não renováveis.

As práticas agricolas que minimizam os efeitos adversos da agricultura sobre o ambiente não coadunam com a homogeneização de manejo, comum hoje em dia. As condições de clima e solo de cada local devem ser respeitadas, as especificidades da situação são as chaves para se orientar o manejo; este fato dificulta a prática da agricultura sustentável em áreas muito extensas. Na pequena produção são mais viáveis as atividades diversificadas, a reciclagem de restos orgânicos e o manejo cuidadoso do solo e da água. Nesta situação, pode-se reconhecer facilmente sistemas de produção eficientes quanto ao uso de recursos energéticos. Falar sobre erosão de solo, como grave problema para a sustentabilidade da produtividade agrícola, é por demais subjetivo se não conhece-se a capacidade daquele solo de regenerar-se. Se não se comparar a taxa de formação deste solo com as taxas de perda não temos qualquer fato que possa provar o temor quanto à erosão.

A excessiva perda de solo, a excessiva homozigose do sistema, o excessivo uso de agroquímicos e a perda da biodiversidade serão considerados simples temores, ou mero alarmismo, se não evidenciarem uma tendência real à insustentabilidade do sistema agrícola.

Energia, ou Eficiência energética dos agroecossistemas como parâmetro para a sustentabilidade ambiental é o seu indicador mais consistente; outros fatores, entretanto são primordiais para a avaliação mais adequada como o uso de recursos não-renováveis e outros danos ambientais que podem advir do processo agrícola. 


\subsubsection{Análise energética e valores para conversão}

Um agroecossistema possui um fluxo complexo de matéria e energia. Encontrase entradas de energia desde aquela relacionada a insumos e serviços até a energia da luz solar e da energia de edificações e benfeitorias da propriedade. As saídas do sistema são também igualmente complexas; ao produzirmos milho podemos dispor do produto tanto como silagem como quanto grão; o resultado do mesmo processo de produção seria completamente diferente. A produtividade de energia da cultura do milho é maior que a da soja, entretanto a soja possui um teor de proteína muito maior. Alguns sistemas de produção podem propiciar uma ótima produtividade, entretanto o uso inadequado de alguns recursos podem estar comprometendo a manutenção do nível de produtividade no futuro. O uso de alguns insumos e a implementação de alguns serviços em uma safra podem trazer benefícios em safras subsequentes apesar de "prejudicar" os resultados da análise daquela própria.

Estas questões vêm caracterizar a complexidade da elaboração de um diagrama das entradas e saídas de um sistema. Uma análise simplista, ou isolada de um sistema de produção, ou de uma safra de uma cultura não permite que se tire qualquer conclusão sobre a eficiência energética ou principalmente da sustentabilidade da atividade analisada.

Ao se analisar o sistema de produção não se deve considerar insumos produzidos dentro da propriedade como entradas exceto pelos bens e serviços externos que tenham sido utilizados para viabilizar sua produção. Esterco do gado da própria propriedade não é contabilizado como esterco; sua produção talvez tenha exigido rações ou adubos que devem ser contabilizados desta forma; neste caso a distribuição do esterco implicará diretamente apenas em um gasto energético de trabalho humano, gasto de máquinas e combustíveis. Caso o esterco venha de uma outra propriedade ele deve ser contabilizado diretamente como esterco.

Analisando-se uma safra (cultura em um ciclo), qualquer entrada deve ser contabilizada, mesmo que seja originária da própria propriedade.

Responder a algumas dessas questões quanto à metodologia de análises 
energéticas de agroecossistemas é um dos principais objetivos do presente trabalho. As respostas a outras questões dependem do objetivo da análise ou mesmo do caso do sistema de produção.

O valor energético dos investimentoss varia de local para local em função da distância do fornecedor e o valor energético final do produtos varia de local para local em função da distância do consumidor.

O tipo de energia utilizada para se gerar um bem ou serviço varia. Esta variação faz com que insumos com valores energéticos semelhantes estejam associados a uma maior ou menor entropia. É como a diferença entre ir-se correndo ou andando, comer-se proteína animal ou vegetal, do carro a álcool ou a gasolina. Para se percorrer 3.000 kilômetros podemos utilizar o avião ou o lombo do burro, mesmo que a energia dispendida fosse a mesma, o serviço aéreo utiliza toneladas de gasolina, ferro minerado e trabalhado, enquanto o lombo do burro necessitou apenas algumas centenas de quilos de capim. A discussão pode tornar-se ainda mais complexa se refletirmos sobre a emissão de metano pelo animal (ponto negativo), ou sobre o esterco produzido (ponto positivo) em comparação com a emissão de gases do avião (ponto negativo).

A análise de todas as externalidades de cada bem ou serviço é um grande fator de complicação, não permite também uma conclusão absoluta pois encontra-se, invariavelmente, processos fazendo parte de uma cadeia sem fim.

Bens ou serviços associados a processos de mineração, uso de energia de alta qualidade, gasto de recursos finitos, contaminação ou poluição não devem ter seus valores energéticos subestimados. A recíproca é verdadeira. Bens ou serviços mais naturais não deveriam ter valores energéticos supervalorizados.

A valoração adequada de cada bem ou serviço é essencial. Um sistema de produção que faça uso de mão-de-obra escrava, financeiramente vantajosa, não deveria ter um balanço energético positivo. Para que a análise cumpra com seus objetivos a valoração deve ser cuidadosamente analisada.

\section{a. Sementes e Outros Propágulos}

Semente não é grão, é um insumo para o qual muitas vezes há uma grande 
demanda energética durante a produção. Muitas culturas, entretanto, vem sendo implantadas com sementes obtidas na própria propriedade e com baixa tecnologia.

Existem, portanto, dois universos distintos: um no qual a semente é um insumo caro e de alta tecnologia e outro no qual a semente é um insumo de baixo custo e tecnologia. Essas diferenças não devem ser omitidas em uma análise energética.

A sementes de alta tecnologia, adquiridas fora da propriedade deveria ser atribuído um valor energético proporcional ao gasto dos sistemas de produção menos eficientes para aquela cultura; o ideal seria que fossem feitos estudos de caso para cada cultura com uma análise de processos dos sistemas de produção de sementes. Como esses dados não estão disponíveis para todas as culturas e a eles não têm acesso a maioria dos agricultores e técnicos, este método sugere uma regra geral na qual adota-se o valor igual ao dobro do valor calórico do grão.

A sementes de baixa tecnologia ou sementes produzidas na propriedade em estudo, deve ser atribuído o valor energético das calorias do grão.

Mudas, rizomas, estacas requerem uma avaliação cuidadosa. No caso da mandioca, seu propágulo, a maniva seria apenas um resto cultural, geralmente obtido na propriedade; não parece razoável que nesse caso seja considerado qualquer valor energético para o propágulo. Entretanto, em casos como o da batata, ou quando o propágulo é obtido de outra propriedade, a resposta não se apresenta tão simples.

A regra geral é que quando o propágulo possuir um valor energético facilmente determinável (batata, alho,...) este seja o valor considerado. Quando for um pedaço do vegetal que se caracterize como resto cultural, o valor deve ser $0 \mathrm{kcal}$, para material obtido na propriedade (no caso de análise do sistema de produção) e um valor genérico como matéria orgânica $15 \mathrm{kcal} / \mathrm{kg}$. Sugere-se, que caso o usuário do método julgue necessário, pode ser feita uma análise simples do processo de produção do propágulo. Sempre que necessário, a análise do processo da produção do propágulo deve ser realizada, principalmente no caso de mudas e propágulos de alta tecnologia. 


\section{b.Nitrogênio}

A liquefação/ solidificação do nitrogênio do ar, tão hábilmente realizada por bactérias fixadoras livres e simbiontes é um processo muito oneroso para a tecnologia humana. Os processos de fixação de nitrogênio por via industrial exigem enormes intensidades de calor e pressão que para serem geradas demandam formas e quantidades de energia que tornam este processo altamente entrópico. Em geral utiliza-se gás natural no processo, um recurso não renovável. No Brasil, as indústrias estão concentradas em uma região, no caso, a região litorânea do estado de São Paulo. Por causa destes fatos, os valores energéticos a serem considerados para o nitrogênio serão os mais altos encontrados na literatura como referência ao custo energético de sua produção. Alguns são calculados através da conversão baseada no valor de $25.000 \mathrm{kcal} / \mathrm{kg}$ de nitrogênio $100 \%$, outros foram calculados com dados específicos encontrados na literatura.

\section{c.Fósforo}

O fósforo é um recurso natural não renovável. O fósforo eliminado nas fezes, ou perdido junto à terra erodida, em geral, segue para o mar no qual vai se acumulando de forma irrecuperável. Existem previsões catastrofistas quanto ao abastecimento de fósforo para a humanidade para os próximos 50 anos. A cada década a dificuldade de extração aumenta devido ao aprofundamento das reservas disponíveis, a cada ano, maiores profundidades tornam-se economicamente viáveis; atualmente são exploradas reservas que 20 anos atrás eram inviáveis. Com certeza, exploração a maiores profundidades implica em maiores gastos energéticos e maiores danos ambientais.

O Brasil possui poucas reservas de fósforo e a maioria delas de baixa qualidade de pureza. A maior parte do fósforo utilizado no Brasil é importado, o que implica no transporte marítimo por longas distâncias. Em vista desses fatos, considerar-se-à para 0 fósforo os valores mais altos encontrados na literatura para produção de fertilizantes fosfatados por serem certamente os mais próximos da realidade e por refletirem de melhor maneira as implicações não consideradas quanto à escassez deste recurso. Alguns são calculados através da conversão baseada no valor de $3.000 \mathrm{kcal} / \mathrm{kg}$ de $\mathbf{P}_{\mathbf{2}} \mathbf{O}_{\mathbf{5}}$ $100 \%$, outros foram calculados com dados específicos encontrados na literatura. 


\section{d. Potássio}

O potássio é um recurso não-renovável cujas perspetivas de abastecimento não afetam a sustentabilidade da agricultura como o fósforo. Alguns são calculados através da conversão baseada no valor de $1.600 \mathrm{kcal} / \mathrm{kg}$ de $\mathbf{K}_{2} \mathbf{O} 100 \%$, outros foram calculados com dados específicos encontrados na literatura.

\section{e. Cálcio e Magnésio}

O processo de acidificação dos solos tropicais, principalmente quando intensamente utilizados é contínuo e inevitável. Haverá sempre a necessidade de corrigir-se solos agrícolas, quanto à acidez e à toxidez de alumínio. Cabe ressaltar que o uso de corretivos como calcário é um grande fator de ganho em produtividade das culturas, tanto pela adequação do $\mathrm{pH}$ e do $\mathrm{V} \%$, quanto pelo aumento da eficiência de uso da maioria dos nutrientes. Outro fato importante é a melhor distribuição das reservas, o que facilita seu transporte aos pontos de uso.

\section{f. Enxofre}

O enxofre é, em geral, adicionado através de outros adubos como Sulfato de Amônio, Sulfato de Potássio ou pelo enchimento de outros adubos quando à base de Gesso. Esta proposta não incluirá, por hora, um índice para conversão de materiais destinados exclusivamente à fertilização sulfúrica.

\section{g. Micronutrientes}

Como o próprio nome indica, são utilizados em pequenas quantidades. Não existem muitos trabalhos que indiquem o valor energético de micronutrientes, como estes podem ser encontrados em diversas formas, a solução mais razoável encontrada é de estimar o valor em função da matriz energética, ou seja $10.141 \mathrm{kcal} / \mathrm{US} \$$.

\section{h. Defensivos Agrícolas}

Os defensivos agrícolas existem, hoje em dia, em uma enorme diversidade. Novos 
princípios ativos são criados diariamente e lançados no mercado. Cada um deles possui um custo energético de produção distinto que implica em valores diferentes para o produto final, qualquer que seja ele, qualquer que seja sua forma. Talvez as indústrias pudessem divulgar esses valores no rótulo do produto, mas enquanto a análise energética não se populariza isto é pouco viável. O mais razoável é que se utilize, por hora, valores genéricos, aproximados. As variações em função da formulação, transporte, embalagem e princípios ativos, apesar de significativas comprometeriam a praticidade da análise energética. A adoção do maior valor se justifica pela distância que percorre o insumo no Brasil, cujo parque industrial é bastante concentrado no estado de São Paulo e pelo potencial poluidor inerente a estes materiais.

\section{i. Trabalho Humano}

A questão da determinação do valor energético do trabalho humano é, provavelmente, a mais complexa de todas. Nesta questão devemos refletir que o

processo agrícola encontra no homem seu começo, meio e fim. Muitos trabalhos humanos poderiam ser substituídos por máquinas e/ou substâncias químicas com alta demanda por energia. Esta possibilidade é considerada desejável por muitos que consideram indignas do homem atividades rudes como a capina. $\mathrm{O}$ filosofar sobre tal questão pode conduzir-nos a reflexões além dos objetivos modestos do presente trabalho, entretanto, perguntemo-nos se foi indigno o trabalho feito por nossos antepassados? São indignas as calosidades nas mãos, o suor no rosto e o cansaço no corpo?

$\mathrm{O}$ que este método considera é que todas as pessoas do mundo devem ter acesso às condições mínimas necessárias às suas vidas. Prescindir do trabalho humano na agricultura significa apenas evitar um gasto extra de energia muscular normalmente necessário nestes trabalhos. Trabalho intelectual na agricultura não deve ter um valor energético atribuído, outras atividades sejam elas braçais ou mecânicas, devem ter considerado um valor que represente a diferença entre o gasto de energia de um trabalho moderado a pesado e o gasto da condição de repouso e trabalhos leves de uma pessoa. $\mathrm{O}$ valor abaixo indicado é uma sugestão desta metodologia fundamentada em dados de 
Pimentel.

\section{j. Trabalho Animal}

A questão do trabalho animal já se afigura mais simples, o animal de tração é mantido totalmente com função de ajudar o homem a melhorar seu desempenho na atividade agrícola. É um mero insumo, a despeito de qualquer carinho que se possa nutrir pelo bicho. O custo de seu trabalho é necessariamente toda a sua demanda energética por alimentos. Caso decida-se por prescindir de seu uso, ele deixará de ser insumo para ser produto.

O gasto energético com operações com trabalho animal deveriam considerar o valor energético da hora trabalhada, o gasto energético com o homem que conduz a parelha e o desgaste dos implementos. O tempo considerado por operação seguiu os dados que podem ser observados no apêndice 12 .

O desgaste dos implementos deve ser considerado em função dos materiais que o compõem e da durabilidade destes materiais. Como em geral tratam-se de equipamentos leves consideraremos este valor desprezível neste método. Interessa-nos o valor maior resultante da soma de $2.400 \mathrm{kcal} /$ hora do animal e $300 \mathrm{kcal} /$ hora do trabalhador humano, ou seja $2.700 \mathrm{kcal} /$ hora trabalhada pelo conjunto.

\section{k. Operações com Máquinas e Transporte}

As operações com máquinas e transportes implicam grandes consumos de energia; em muitos sistemas de produção, o uso de implementos para preparo de solo, defesa da cultura e colheita é responsável pela maior parte do consumo de energia da cultura. A estes serviços estão associados custos diretos, os combustíveis, e indiretos, relacionados à depreciação dos materiais. Como cálculos como este, normalmente, são muito complexos e dificultam o uso por parte de técnicos e agricultores, o método de análise aqui proposto faz uma compilação e uma simplificação máxima dos valores das operações agrícolas mais comuns. Fontes de variação como tipo de solo, umidade, presença ou não de restos culturais e cuidados dispensados à prevenção do desgaste dos 
materiais são consideradas muito exclusivas de cada caso, cada sistema ou produtor.

Os dados da tabela 38 foram calculados com a soma da energia indireta com o desgaste dos materiais ( $\mathrm{kg} / \mathrm{hora}$ ), o número de horas médio para cada operação, a energia gasta pelo operador e o consumo de combustível. Todos este dados podem ser observados nos apêndices 11,12 e 13 Considerou-se que cada kg de material equivale a $18.000 \mathrm{kcal}$ e que cada hora do operador $300 \mathrm{kcal}$.

Os dados para colheita e manutenção de terraços são parte da proposta de Mello (1986), os demais dados foram calculados nesta proposta. Os dados de aração são calculados para arado de discos a uma profundidade de $18 \mathrm{~cm}$ em solo médio, a gradagem para grade leve em tandem. Considere-se que a escarificação profunda é equivalente ao cultivo com enxadas rotativas e a distribuição de materiais sólidos à semeadura. A composição dos dados pode ser observada na tabela 38 .

Tabela 38: Fatores de conversão de energia para diferentes operações mecânicas

\begin{tabular}{lccccc}
\hline & kg/hora & horas & E indireta & E. direta & E total/ha \\
\hline Aração & 1,3 & 2 & 47580 & 88430 & 136010 \\
Gradagem & 2,37 & 0,5 & 21685,5 & 26290 & 47975,5 \\
Pulverização & 0,94 & 0,5 & 8601 & 1434 & 10035 \\
Semeadura & 2,01 & 0,5 & 18391,5 & 13145 & 31536,5 \\
Cultivo & 0,98 & 0,5 & 8967 & 133242 & 142209 \\
Colheita & & & & & 168463 \\
Manutenção de terraços & & & & & 27567 \\
\hline
\end{tabular}

Os produtos devem ter acrescidos ao seu custo energético o valor do transporte na medida em que isto ocorra.

Todo insumo transportado por grandes distâncias deve ter o valor energético do transporte considerado; em materiais como o calcário, o valor energético do transporte pode superar o valor energético do material.

Considera-se para este método os valores sugeridos por Flück \& Baird (1982), por considerarem a energia direta e indireta dos diferentes sistemas de transporte. 


\section{Irrigação}

Os custos financeiros da irrigação poderão sofrer grandes influências nos próximos tempos, a partir do momento em que diversos paises, inclusive o Brasil, começam a discutir formas de taxar o uso da água captada nos cursos d'água e lençois freáticos, tanto para uso industrial, quanto urbano e agrícola.

O custo energético, entretanto, não sofrerá variações; os valores energéticos que se consideram neste método dependem da quantidade de água irrigada, do sistema de irrigação e da altura de recalque da água. São esses, indubitavelmente, as maiores fontes de variação desses valores. Os dados apresentados na tabela 15 são uma proposta desta metodologia fundamentada em dados que podem ser analisados nos apêndices $18,19 \mathrm{e}$ 20 .

\section{m. Terra}

Três questões devem ser discutidas quanto à valoração energética da terra:

1)A terra como uma área na qual o sistema de produção capta diversas formas de energia como luz solar, água da chuva e gases essenciais à produção. A intensidade com a qual esses recursos entram em uma área varia muito com à localização desta propriedade e com a época do ano. Precisamos decidir se devemos ou não considerar este valor, e em caso positivo, definir qual deva ser.

2)A terra pelo seu valor financeiro. Para possuir esta rede de captação de diversas formas de energia o agricultor precisa possuir esta terra, devendo tê-la comprado, arrendado ou herdado. Existem maneiras, já discutidas por Fluck \& Baird (1982), de considerar-se o valor energético baseado em seu custo.

3)A terra pode ter um valor considerado em função de sua depreciação (perdas) ou valorização (ganhos). Esta variação de valor energético refere-se às oscilações da qualidade desta terra. Não existem maneiras viáveis de considerarmos as perdas ou ganhos físicos ou biológicos de um solo; teoricamente estas variações refletem-se na eficiência energética da cultura ou do sistema ao longo de vários anos ou ciclos de análise. As variações da fertilidade do solo, entretanto, podem ser diretamente correlacionadas aos valores energéticos das fertilizações equivalentes a essas variações. 
Segundo o método proposto a terra não pode ser considerada em função de seu valor de mercado, uma vez que ela não é uma mercadoria que deva ser sub-utilizada para que sirva a aplicações financeiras ou imobiliárias. A terra é a base da vida na Terra e possui uma função social, claramente considerada por este método. A terra deve servir para garantir a segurança alimentar mundial e seu valor energético está associado ao custo de oportunidade da energia radiante que nela incide. A terra, ou o seu uso, não implica em um ônus energético, não implica necessariamente em um aumento do processo de consumo de matéria e energia de baixa entropia. A energia solar não é portanto considerada para efeito de cálculo da energia necessária à produção agrícola; entretanto a radiação solar incidente é o parâmetro que utilizaremos neste método para avaliarmos a eficiência fotossintética líquida dos sistemas de produção. As principais fontes de variação para a intensidade da radiação incidente, que será considerada neste método, para efeito de simplificação do uso, são latitude e estação.

Os valores para radiação solar variam entre 2739,7 e 5479,5 kcal.m ${ }^{-2}$.ou 27,4 e $54,8 \times 10^{6} \mathrm{kcal} . \mathrm{m}^{-2}$ por dia, em média no mundo.

$\mathrm{O}$ apêndice 21 é uma aproximação que pode ser utilizada sempre que não se dispuser de um dado local mais preciso. O ideal é utilizar dados de postos metereológicos próximos.

\section{n. Insumos Orgânicos}

Insumos orgânicos só devem ser considerados na análise energética quando forem obtidos fora da unidade de produção. Poderão ainda ser considerados como produtos quando forem exportados para outras unidades fora do sistema analisado, ou ainda quando forem comercializados.

Quando contabilizados, deverão ser utilizados valores iguais ao valor calórico da matéria orgânica acrescido da energia do transporte sempre que necessário.

Para a análise do sistema de produção, os insumos gerados dentro da propriedade em estudo não devem fazer parte da análise, as entradas energéticas restringem-se às externas à propriedade. 


\section{o. Outros Insumos}

Os valores adotados podem ser determinados através de análise de processo, matriz energética ou segundo o valor de algum produto correlato.

Sacaria de polietileno pode ter seu valor considerado segundo o valor genérico para polietileno, ou seja, $25.979,92 \mathrm{kcal} / \mathrm{kg}$.

Mulch plástico pode ser convertido pelo fator de conversão $2.275,33 \mathrm{kcal} / \mathrm{kg}$, igual ao valor geral para plásticos, encontrado na bibliografia.

O Grafite, utilizado nas semeaduras de grãos, pode ter considerado um valor energético próximo ao seu valor calórico que é o valor calórico do carvão ( 7.800 $\mathrm{kcal} / \mathrm{kg}$ ).

Substratos Organo-minerais, Vermiculita e outros insumos podem ser convertidos com o valor de $10.141 \mathrm{kcal} /$ US\$.

\section{p. Outros Serviços}

Os valores de serviços não indicados neste trabalho devem ser gerados através de análises de processo. A complexidade da análise dependerá do nível de precisão desejado.

\section{q. Produtos}

Duas questões afetam a análise dos produtos, a questão dos produtos múltiplos e a qualidade dos produtoss.

Produtos múltiplos: podem ser resíduos que não devem ser considerados na análise do sistema pois fazem parte dele. Em análises de glebas, o resíduo pode ser considerado como nutriente. Subprodutos vendidos ou retirados da propriedade devem ser considerados para a análise do produto.

Qualidade dos produtos: Valor biológico dos produtos, produtos mais saudáveis, com menor índice de contaminação com agroquímicos ou com melhores características organolépticas deveriam ter estas vantagens indexadas ao resultado, entretanto, cabe ressaltar que esta proposta considera como essencial o atendimento às necessidades da população. A partir do momento em que a agricultura atender às necessidade mínimas 
de toda a população, de modo sustentável, a complexificação da análise do produto poderá incluída à estrutura do método.

\subsection{Sobre os sistemas analisados}

O sistema melhor avaliado quanto ao índice "SER" foi o PDT (Plantio direto sem adubação de fósforo e potássio), em virtude de sua superioridade nos índices de energia e rentabilidade como pode ser observado na tabela 37 .

O milho é uma das culturas com maior potencial para a sustentabilidade, têm grande capacidade fotossintética, alto potencial de produção, adequados teores de proteína e valor calórico. Não tende, normalmente, a propiciar alta rentabilidade por hectare, como cultura alimentícia largamente explorada, seus preços mantém-se baixos, e a lucratividade na cultura depende, normalmente do cultivo em módulos acima de 100 hectares. Os índices para segurança e energia, entretanto, foram inferiores aos de rentabilidade, na média. A alta dependência de recursos energéticos e o baixo balanço foram os responsáveis pela piora do índice de energia, como podemos observar nas tabelas 33, 34, 35 e 36, que só não foram ainda mais baixos porque a eficiência fotossintética, natural para uma planta de metabolismo " $\mathrm{C}_{4}$ " como o milho, contribuiu para a melhoria destes. Quanto à segurança alimentar, os índices de todos os sistemas foram baixos. A explicação para este fato encontra-se na estrutura do método; a maioria dos sistemas é insustentável se obrigada a atender à demanda absurda de uma sociedade consumista de 10 bilhões de pessoas. Quando a expectativa da demanda modificar-se, seja por uma redução do crescimento populacional ou por uma modificação dos padrões de consumo, este índice melhorará para todas as culturas e, certamente, a cultura do milho, independente do sistema de produção, atingirá bons índices para segurança alimentar.

Os sistemas com plantio direto foram os mais produtivos dentre os avaliados, e consequentemente, os que obtiveram os melhores índices para segurança alimentar, como revela a tabela 37. A superioridade dos sistemas com plantio direto vêm desmentir a hipótese de que o sistema deva ser modificado após vários anos em virtude de 
compactação e/ou concentração sub-superficial de fertilizantes. A movimentação de solo com grade aradora não melhorou a sustentabilidade do sistema com relação a seus índices de segurança, energia ou rentabilidade.

Os sistemas com fertilização fundamentada na expectativa de exportação foram os menos eficientes energética e economicamente, segundo a metodologia de análise proposta.

Em média os melhores índices dos sistemas foram os índices de rentabilidade os quais apresentaram as maiores variações.

A adubação nitrogenada foi o item que mais afetou a análise energética, isto fez com que os índices aferidos não variassem tanto entre os sistemas avaliados. Fica evidente através da análise da planilha de consumo de energia dos sistemas que há a necessidade de se modificar os sistemas quanto ao uso de fertilizantes nitrogenados. $\mathrm{O}$ custo energético da adubação nitrogenada representou $76 \%$, como se vê na tabela 32 , do total do sistema de produção PDT. Este valor demonstra a possibilidade de melhorar os índices energéticos do sistema adotando-se práticas que minimizem o uso destes fertilizantes. Dentre estas práticas destaca-se a rotação com leguminosas, a adubação orgânica, a adubação verde e a consorciação com leguminosas.

Esta percepção não é possível através do uso exclusivo da análise econômica, onde os gastos com adubação variaram entre 37 e 53\% do total, como se observa nas tabelas 25, 26, 27 e 28, sendo que a adubação nitrogenada, na adubação EG (a mais onerosa) representam menos de 50\% do total dos gastos com fertilização. Assim, o item adubação nitrogenada não se evidenciou como problemático para o tomador de decisão. Através da análise energética pode-se perceber que a adubação nitrogenada foi o maior fator de insustentabilidade dos 4 sistemas de produção analisados.

As operações mecânicas comportaram-se de maneira oposta, prejudicaram a sustentabilidade dos sistemas, principalmente nos sistemas com gradagem, apenas quanto aos índices econômicos, como se pode obsevar nas planilhas econômicas e energéticas (Tabelas 25-32).

Os defensivos agrícolas tiveram peso homogêneo nas análises econômicas e energéticas, entre 9 e $12 \%$ dos investimentos energéticos totais e entre 8 e $13 \%$ do custo 
de produção (tabelas 25-32)

Em geral os sistemas com menores doses de adubação propiciaram os melhores índices quanto à energia e rentabilidade.

Certamente, esta análise, se feita em parceria com o agricultor, permitiria que este obtivesse todas estas constatações sobre sua propriedade ou modo de produção o que poderia, certamente, contribuir para o seu processo de tomada de decisão.

Assim, o processo de formulação do índice é tão importante quanto o próprio índice, através do processo, agricultores e técnicos buscam a análise global de seus sistemas de produção em busca de orientações para reformulação das atitudes e processos específicos.

\subsection{Considerações finais}

Face ao ineditismo e à originalidade do método proposto, pode-se inferir que a) Deveriam ser feitos trabalhos buscando-se a definição mais precisa dos valores energéticos de bens e serviços utilizados no setor agrícola; b) Seriam muito úteis trabalhos com cálculos comparativos dos gastos energéticos dos diferentes tratamentos (processamentos, embalagens) pós - colheita e formas de transporte dos produtos agrícolas e florestais; c) Seriam extremamente úteis para o aprimoramento do método proposto estudos de caso utilizando-o com diferentes categorias de produtores e diferentes sistemas de produção; d) Poderiam ser feitos trabalhos que tenham por objetivo acrescentar ao método proposto outros parâmetros como poluição de solo e água, conservação de estradas, qualidade de vida do produtor e dos trabalhadores rurais e e) Faz-se necessário o estudo das possibilidades de substituição das formas de energia utilizadas por formas renováveis de energia e das taxas de substituição de energias nãorenováveis por renováveis sob diferentes cenários de consumo. 


\section{CONCLUSÕES}

a) A análise dos índices e da planilha energética propostos podem orientar o processo de tomada de decisão de agricultores e técnicos, no sentido de promover alterações ou inovações no sistema de produção objetivando o aumento do grau de sustentabilidade.

b) O método proposto possibilita a adequada avaliação do grau de sustentabilidade de sistemas de produção, fornecendo um índice "multifuncional" para a sua respectiva análise. 


\section{BIBLIOGRAFIA}

AGRIANUAL 98. Anuário da Agricultura Brasileira. Organizadores: NEHMI, I.M.P.; FERRAZ,J.V. NEHMI FILHO,V.A 481 p.

ALHO, C.J.A. A Teia da vida: uma introdução à ecologia brasileira. Rio de Janeiro: Objetiva, 1992. 160p.

ALTIERI, M. Agroecologia: as bases científicas da agricultura alternativa. Rio de Janeiro: PTA/F ASE, 1989. 60p.

ALTIERI, M. Sustainability and the rural poor: a Latin American perspective. In: ALTIERI, M. Agroecology. Nova York: Westview Press Boulder, 1993. p.193-209. $227 \mathrm{p}$.

BEGOSSI, A. Aspectos de economia ecológica: modelos evolutivos, manejo comum e aplicações. In: ROMEIRO, A.R.; REYDON, B.P.; LEONARDI, M.L.A (Orgs.) Economia do meio ambiente: teoria, políticas e a gestão de espaços regionais. Campinas: UNICAMP/ I.E., 1996. p.43-51.

BENBROOK, C.M. A agricultura americana caminha para a sustentabilidade? Estudos Econômicos, v.24, p.115-155, 1994. Número especial.

BIRD, G.W.; IKERD, J. A agricultura sustentável: um sistema do século XXI. Estudos Econômicos, v. 24, p.95-114, 1994.Número especial. 
BONGAARTS,J. Population policy options in the developing world. Science, v.263, p.771-776, 1994.

BRIGGLE, L.W. Introduction to energy use in wheat production. In: PIMENTEL, D. (Ed.) Handbook of energy utilization in agriculture. Florida CRC Press/ Cornel University New York, 1980. 475p.. p.109-116.

BROWN, L.R. A nova ordem mundial In: BROWN, L.R. (Ed.) Qualidade de Vida 1991: Salve o planeta! São Paulo: Globo, 1991. cap.1,p.21-41.

BÜLL, L.T. Nutrição mineral do milho. In: BÜLL, L.T.; CANTARELLA, H. (Ed.) Cultura do milho: fatores que afetam a produtividade. Piracicaba: POTAFOS, 1993. p.63-145.

CAMINO, R.V.; MÜLLER, S. Sostenibilidad de la agricultura y los recursos naturales: bases para establecer indicadores - San José/Instituto Interamericano de Cooperación para la Agricultura: IICA/GTZ, 1993. 134p.

CAMPANHOLA, C.; LUIZ, A.J.B.; LUCCHIARI JÚNIOR, A. O problema ambiental no Brasil: agricultura. In: ROMEIRO, A.R.; REYDON, B.P.; LEONARDI, M.L.A (Orgs.) Economia do meio ambiente: teoria, políticas e a gestão de espaços regionais. Campinas: UNICAMP/I.E., 1996. p. 265-281.

CAVALCANTI, C. Condicionantes biofísicos da economia e suas implicações quanto à noção do desenvolvimento sustentável In: ROMEIRO, A.R.; REYDON, B.P.; LEONARDI, M.L.A (Orgs.) Economia do meio ambiente: teoria, políticas e a gestão de espaços regionais. Campinas: UNICAMP/ I.E., 1996. p. 61-82. 
CENTRO DE TECNOLOGIA DE ALTERNATIVAS POPULARES Construindo uma metodologia para o desenvolvimento rural sustentável. In: CONFERÊNCIA INTERNACIONAL "TECNOLOGIA E DESENVOLVIMENTO SUSTENTÁVEL”. Porto Alegre, 1995. Anais. Porto Alegre: UFRGS, 1995. p.1-14.

COLE, L.C. Jogando roleta russa com os ciclos biogeoquímicos. In: A crise ambiental: a luta do homem para viver consigo.1974. p.11-23.

COMITRE, V. A questão energética e o padrão tecnológico da agricultura brasileira. Informações Econômicas, v.25, n.12, p.29-35, Dez. 1995.

CONWAY, G.R. The properties of agroecosystems. Agricultural systems, v.24, p.95117, 1992.

COOK, E. Man, energy, society. San Francisco: W.H. FREEMAN and Co, 1976.

COOMBS,J.; HALL,D.O; CHARTIER,P. Plant as solar collectors optimizing productivity for energy: an assessment study. Reidel Publishing Company, 1983. 210p.

CUNHA, A.S. Uma avaliação da sustentabilidade da agricultura nos cerrados. Brasília: IPEA, 1994. 256p.

DALY, H. Allocation, distribution and scale: towards na economics that is efficient, just, and sustainable. Ecological Economics, v.6, p.185-193, 1992.

EHLERS, E. Agricultura sustentável: Origens e perspectivas de um novo paradigma. São Paulo: Livros da Terra, 1996. 178p. 
EHRLICH, P. Ecological economics and the carrying capacity of earth. In: JANSSON, A. et al. (Ed.) Investing in natural capital. Covelo: Island Press, 1994. p.38-56.

FANCELLI, A.L. Sistemas de produção. Cursos Agrozootécnicos; SEBRAE-SP, 1994. $197 \mathrm{p}$.

FAO. Relatório da conferência da FAO/Holanda sobre agricultura e meio ambiente, 1991. Agricultura sustentável. n.45, p.16, 1992.

FAO Yearbook Production 1997. Rome, v. 51, n.142. 1998. 241p. FAO Statistics Series.

FAO The state of food and agriculture: rural non-farm income in developing countries. Rome, 1998. 373p.

FAO. Traditional systems of veterinary medicine for small farmers in Nepal. Bangkok, 1984. (FAO - RAPA).

FLAVIN, C.; LENSSEN, N. Planejando um sistema energético sustentável In: BROWN, L.R. (Ed.) Qualidade de Vida 1991: Salve o planeta! São Paulo: Globo, 1991.cap.2, p.43-64.

FRANCO, G. Tabela de composição química dos alimentos. 8.ed. Rio de Janeiro: Atheneu Editora. 1989. 230p.

FLORES, M. et al. Pesquisa para a agricultura auto-sustentável. Revista Brasileira. de Economia e Sociologia Rural, v.29, n.1, p.1-21. 1991. 
FLUCK, R.C.; BAIRD, C.D. Agricultural energetics. Gainesville: University of Flórida/Agricultural Engineering Department and Institute of Food and Agricultural Sciences. 1982. 197p.

GALJART, B. Difusão cultural, modernização e subdesenvolvimento. In: Queda, O; Szmrecsányi, T. (Orgs.) Vida rural e mudança social: leituras básicas de sociologia rural. São Paulo: Editora Nacional, 1972. cap.5, p.70-79.

GIPS, T. What is sustainable agriculture? In: INTERNATIONAL SCIENTIFIC CONFERENCE OF THE INTERNATIONAL FEDERATION OF ORGANIC AGRICUlture MOVEMENTS, 6., Santa Cruz, 1986. Proceeding. Santa Cruz: Agroecology Program/University of California, v.1, 1986.p.63-74.

GIRT, J. The sustentainable development of agriculture in Latin America and the Caribbean: strategic recommendation. Instituto Interamericano de Cooperação para Agricultura, 1990.

GOEDERT, W.J. Uso e manejo dos recursos naturais do cerrado: solo e clima. In: SIMPÓSIO SOBRE O CERRADO, 5.,Brasília, 1979. Anais. Brasília: Editerra, 1980. p.475-498.

GOLDEMBERG, J. Energia, meio ambiente e desenvolvimento. Trad. De A. Koch. São Paulo: Editora da Universidade de São Paulo, 1998. 234p.

GOMDE, J. de C.; KLUTHCOUSKI, J.; YOKOYAMA, L.P.; OLIVEIRA, I.P. de; DUTRA, L.G.; PINHEIRO, B.da S.; SILVA, A E.; DA BALBINO, L.C. Validação e tranferência de tecnologia no cerrado: novo enfoque. Goiânia: EMBRAPACNPAF-APA, 1995. 31p. (EMBRAPA-CNPAF. Documentos, 61). 
GORGATTI NETO, A.; SOUSA DIAS, J.M.C. Política Energética para a Agricultura In: Energia na agricultura: tecnologias poupadoras de insumos, integração de sistemas energéticos, produção de alimentos. Jaboticabal: FUNESP, 1985. cap.1, p.4-22.

HALL, C.A S; HALL, N.H.P. The efficiency of land and energy use in tropical economics and agriculture. In: Edwards,C.A (Ed.) Agriculture and the environment. Columbus: Ed. Elsevier, 1993. p.1-31.

HOBBELINK, H. Biotecnologia: muito além da revolução verde. AGE/POA, 1990. $143 p$.

INSTITUTO INTERAMERICANO DE COOPERACIÓN PARA LA AGRICULTURA/DEUTSCHE GESELLSCHAFT FÜR TECHNISCHE ZUSAMMENARBEIT. Tecnologia y sostenibilidad de la agricultura en America Latina: desarrolo de um marco conceptual. São José: CID, 1992. p.29-30.

KARLEN, D.L.; DUFFY, M.D.; COLVIN, T.S. Nutrient, Labor, Energy and Economic Evaluations of Two Farming Systems in Iowa. Journal of Production in Agriculture, v.8, n. 4, p. 540-546, 1995.

KLUTHCOUSKI, J. Efeito de manejo em alguns atributos de um latossolo roxo sob cerrado e nas características produtivas de milho, soja, arroz e feijão, após oito anos de plantio direto. Piracicaba, 1998. 179p. Tese (Doutorado) - Escola Superior de Agricultura "Luiz de Queiroz", Universidade de São Paulo.

JANUZZI, G.de M. (Org.). Introdução ao estudo do planejamento de sistemas energéticos. Campinas: NEPAM/UNICAMP, 1994. 50p. (Textos NEPAM: Apoio à Coletividade n. 01) 
LEACH, G. Energy and food production. International institute for Environment and Development. New Hampshire, 1975. 151p.

LENSSEN, N. A provisão de energia nos países em desenvolvimento sustentável In: BROWN, L.R. (Ed.) Qualidade de Vida 1991: Salve o planeta! São Paulo: Globo, 1993. cap. 6, p. 141-163.

LEONARDI, M.L.A. Educação ambiental e teorias econômicas: primeiras aproximações. In: ROMEIRO, A.R.; REYDON, B.P.; LEONARDI, M.L.A (Orgs.) Economia do meio ambiente: teoria, políticas e a gestão de espaços regionais. Campinas: UNICAMP/ I.E., 1996. p. 241-262

LOCKERETZ, W. (Ed.) Agriculture and Energy. New York: Academic Press Inc., 1977.

LOOMIS,R.S.; CONNOR, D.J. Crop Ecology: productivity and management in agricultural systems. Cambridge University Press, 1996. 538p.

LOPES, A.S. Capacidade suporte de ecossistemas. In: TAUK, S.M. et al. (Org.) Análise ambiental: estratégias e ações. Rio Claro: UNESP, 1995. cap.2, p.103-118.

MAALOUF, W. D. Recursos humanos e desenvolvimento agrícola sustentado. São Paulo: Fundação Salim Farah Maluf, 1993. 47p.

MALAGODI, M.A.S. Estudo sobre um programa de reflorestamento ciliar: subsídios para compreensão das relações entre extensão rural e educação ambiental. Piracicaba, 1999. 309p. Dissertação (M.S.)-Escola Superior de Agricultura "Luiz de Queiroz", Universidade de São Paulo. 
MALAVOLTA, E. Manual de química agrícola adubos e adubação. 3.ed. São Paulo: Editora Agronômica Ceres, 1981.600p.

MARQUES, J.F.; COMUNE, A.E. A teoria neoclássica e a valoração ambiental. In: ROMEIRO, A.R.; REYDON, B.P.; LEONARDI, M.L.A (Orgs.) Economia do meio ambiente: teoria, políticas e a gestão de espaços regionais. Campinas: UNICAMP/ I.E., 1996. p.21-42.

MARTEN, G.G. Productivity, stability, sustainability, equitability and autonomy as properties for agroecosystem assessment. Agricultural systems v.26, p.291-316, 1988.

MAY, P.H. Avaliação integrada da economia e do meio ambiente: propostas conceituais e metodológicas. In: ROMEIRO, A.R.; REYDON, B.P.; LEONARDI, M.L.A (Orgs.) Economia do meio ambiente: teoria, políticas e a gestão de espaços regionais. Campinas: UNICAMP/ I.E., 1996. p.54-82.

MELLO, R. Análise energética de agroecossistemas: o caso de Santa Catarina. Florianópolis, 1986. 139p. Dissertação (M.S.)-Universidade Federal de Santa Catarina.

MIELNICZUCK, J. A sustentabilidade agrícola e o plantio direto. In: CONGRESSO BRASLEEIRO DE PLANTIO DIRETO PARA UMA AGRICULTURA SUSTENTÁVEL, 1. Anais. Ponta Grossa, 1996.

NATIONAL RESEARCH COUNCIL. Alternative agriculture. Washington: National Academy Press, 1991. p.3. 
ODUM, E.P. Ecologia. São Paulo: Editora da Universidade de São Paulo, 1969. 201p.

ODUM, E.P. Fundamentos da Ecologia. Lisboa: Fundação Calauste, 1959. 567p.

PENEIREIRO, F. Agricultura Sustentável / Apresentado na Disciplina Sistemas de Produção da ESALQ-USP, Piracicaba, 1995.

PEREIRA, L.R.; BOUGLÉ, B.R.; PORTELLA, J.A. Sistema de Produção Trigo-SojaResultados Trigo, 1976. In: REUNIÃO NACIONAL DE PESQUISA DE TRIGO,13., Cruz Alta, 1984. Anais. Cruz Alta, 1984.

PIMENTEL, D. (Ed.) Handbook of energy utilization in agriculture. Florida CRC Press/Cornel University New York: Boca Raton, 1980. 475p.

PIMENTEL, D. et al. Food production and the energy crises. Science, v.182. p.443-449, Nov. 1973.

PIMENTEL, D.; BERARDI, G.; FAST, S. Energy efficiencies of farming wheat, corn and potatoes organically. In: Organic farming and its role in a sustainable agriculture 1984. p.151-161.

PRIMAVESI, O. A compactação de solos agrícolas. Informações Agronômicas, n.29, p.1-3, Mar. 1985.

PRIMAVESI, A. Manejo ecológico do solo: a agricultura em regiões tropicais. 9.ed. São Paulo: Nobel, 1990. 549p.

QUEDA, O Extensão rural no Brasil: da Anunciação ao milagre da modernização agrícola. Piracicaba, 1987. Tese (Livre-Docência). Escola Superior de Agricultura 
“Luiz de Queiroz", Universidade de São Paulo.

REIJNTJES, C.; HAVERKORT, B.; WATERS-BAYER, A. Agricultura para o futuro: uma introdução à agricultura sustentável e de baixo uso de insumos externos. Rio de Janeiro: AS-PTA - ILEIA-ETC Trad. de J. C. Comerford. 1994, $324 \mathrm{p}$.

ROMEIRO, A.R.; REYDON, B.P.; LEONARDI, M.L.A (Orgs.) Economia do meio ambiente: teoria, políticas e a gestão de espaços regionais. Campinas: UNICAMP/ I.E., 1996. 384p.

ROMEIRO, A R.; SALLES FILHO, S. Dinâmica de inovações sob restrição ambiental. ROMEIRO, A.R.; REYDON, B.P.; LEONARDI, M.L.A (Orgs.) Economia do meio ambiente: teoria, políticas e a gestão de espaços regionais. Campinas: UNICAMP/ I.E., 1996. p.83-122.

SANTOS, H.P. Efeito da rotação de culturas no rendimento, na eficiência energética e econômica do trigo, em plantio direto. Piracicaba, 1992. 136p. Tese (Doutorado)Escola Superior de Agricultura "Luiz de Queiroz", Universidade de São Paulo.

SANTOS, H.P.; FANCELLI, A.L.; REIS, E.M. Balanço energético de sistemas de rotação de culturas para trigo, em plantio direto. Pesquisa Agropecuária Brasileira, v.29, n.7, p.1067-1073, Jul. 1994.

SCHUMACHER, E. F. O negócio é ser pequeno: um estudo de economia que leva em conta as pessoas. Trad. Octávio Alves Velho. Rio de Janeiro: Zahar Editores, 1977. 261p.

SERRA, G.E. et al. Avaliação da energia investida na fase agrícola de algumas culturas. São Paulo: USP/ Instituto de Física, 1979. 86 p. (Relatório Final à 
Secretaria de tecnologia Industrial, Ministério da Indústria e Comércio).

SMYTH, A.J.; DUMANSKI, J. A framework for evaluating sustainable land management. Can. J. Soil Science, v.75, p.401-406. 1995.

SORRENTINO, M.; CHAVES, A.D.M. Agricultura familiar sustentável: contribuições para o plano de gestão ambiental da ESALQ. Piracicaba, 1998. 191p. (Relatório final apresentado à Comissão Científica da FAPESP).

SORRENTINO, M. Educação Ambiental e universidade: um estudo de caso. São Paulo, 1995. Tese (Douturado)-Faculdade de Educação da Universidade de São Paulo.

SOTERO, P. Mundo perde guerra contra a miséria (desenvolvimento) - comentários sobre WDR (World Development Report) do BIRD. Estado de São Paulo. Caderno Internacional. São Paulo, 16 set. 1999. p.A13-A16.

STANHILL, G. Energy and agriculture. Advanced Series in Agriculture Sciences, Heidelberg: Springer Verlag, n.14, 192p. 1984.

STRAHM, R.H. Warum sie so arm sind: arbeitsbuch zur entwicklung der unterentwicklung in der dritten welt mit schaubildern und kommentaren. Taschenbuch: Peter- Hammer, 1989. 217p.

TEICH, D. H. ; NOGUEIRA, P. O bebê número 6 bilhões : demografia. Veja, ano 32, n.39, setembro de 1999. Edição 1617. Abril. p. 84-89.

TRIGO, E.; KAIMOWITZ, D.; FLORES, R. Bases para uma agenda de trabalho visando o desenvolvimento agropecuário sustentável. Estudos econômicos, v.24, p.31-97, 1994. Número especial. 
VEIGA, J.E. da Problemas da transição à agricultura sustentável Estudos Econômicos, v.24, p.9-29, 1994. Número especial.

VIEIRA, M.J. et al. Cultivo mínimo comparado a outros sistemas In: FERREIRA, M.E. Energia na Agricultura: tecnologias poupadoras de insumos, integração de sistemas energéticos, produção de alimentos. Jaboticabal: FUNESP, 1984, p.33-100.

WÜNSCH, J.A. Diagnóstico e tipificação de sistemas de produção: procedimento para ações de desenvolvimento regional. Piracicaba, 1995. 178p. Dissertação (M.S.)Escola Superior de Agricultura "Luiz de Queiroz", Universidade de São Paulo. 


\section{APÊNDICES}

Apêndice 1: Planilha para análise de investimentos financeiros e energéticos do método 'SER"

\begin{tabular}{|c|c|c|c|c|c|c|}
\hline & $\begin{array}{c}\text { Valor em } \\
\text { kcal/unidade }\end{array}$ & unidade & $\begin{array}{l}\text { Custo em } R \$ \\
\text { por unidade }\end{array}$ & $\begin{array}{c}\text { Quantidade } \\
\text { utilizada }\end{array}$ & $\begin{array}{l}\mathrm{R} \$ \\
\text { total }\end{array}$ & $\begin{array}{l}\text { Kcal } \\
\text { total }\end{array}$ \\
\hline Semente & & $\mathrm{kg}$ & & & & \\
\hline Semeadura & & ha & & & & \\
\hline Aração & & ha & & & & \\
\hline Gradagem & & ha & & & & \\
\hline Sub-solagem & & ha & & & & \\
\hline Escarificação & & ha & & & & \\
\hline Pulverização & & ha & & & & \\
\hline Colheita & & ha & & & & \\
\hline Adubação & & ha & & & & \\
\hline $\mathrm{N}$ & & $\mathrm{kg}$ & & & & \\
\hline $\mathrm{P}_{2} \mathrm{O}_{5}$ & & $\mathrm{~kg}$ & & & & \\
\hline $\mathrm{K}_{2} \mathrm{O}$ & & $\mathrm{kg}$ & & & & \\
\hline Calcáreo & & $\mathrm{kg}$ & & & & \\
\hline $\mathrm{S}$ & & $\mathrm{kg}$ & & & & \\
\hline Micronutrientes & & $\mathrm{kg}$ & & & & \\
\hline Cupim/Formicida & & $\mathrm{kg}$ & & & & \\
\hline Herbicida & & $\mathrm{kg}$ & & & & \\
\hline Inseticida & & $\mathrm{kg}$ & & & & \\
\hline Fungicida & & $\mathrm{kg}$ & & & & \\
\hline Esterco & & $\mathrm{kg}$ & & & & \\
\hline Capina & & ha & & & & \\
\hline Irrigação & & $\mathrm{mm} / \mathrm{ha}$ & & & & \\
\hline Trabalho & & h.h & & & & \\
\hline Espalhante & & $\mathrm{kg}$ & & & & \\
\hline Grafite & & $\mathrm{kg}$ & & & & \\
\hline Transporte & & t. $\mathrm{km}$ & & & & \\
\hline Outros & & & & & & \\
\hline Produtos & & $\mathrm{kg}$ & & & & \\
\hline
\end{tabular}


Apêndice 2: Conversão de Unidades

\begin{tabular}{|c|c|c|c|c|c|c|}
\hline & BTU & Kcal & joules & hp & tep & kWh \\
\hline BTU & - & 0,252 & 1.055 & 0,00039 & & 0,00029 \\
\hline kcal & 4 & -- & 4.184 & $5,0 \times 10^{-7}$ & & $3,8 \times 10^{-7}$ \\
\hline Joules & 0,00095 & 0,000239 & -- & $3,7 \times 10^{-7}$ & & $2,8 \times 10^{-7}$ \\
\hline $\begin{array}{l}\text { Hp } \\
\text { tep }\end{array}$ & 2500 & $\begin{array}{c}640 \\
10,7 \times 10^{9}\end{array}$ & $\begin{array}{r}2.700 .000 \\
45 \times 10^{9}\end{array}$ & -- & - & $\begin{array}{c}0,75 \\
12,5 \times 10^{3}\end{array}$ \\
\hline kWh & 3400 & 860 & 3.600 .000 & 1,3 & & - \\
\hline
\end{tabular}

Apêndice3: Políticas para a sustentabilidade

\begin{tabular}{|c|c|c|c|}
\hline Tipo de política & Propósito Geral & Instrumento & Impacto esperado \\
\hline \multirow{3}{*}{ 1.Macrocconômica } & $\begin{array}{l}\text { Ajustar preços } \\
\text { relativos }\end{array}$ & Desvalorização & $\begin{array}{l}\text { Mais rentável investir em agricultura } \\
\text { Menos rentável usar capital } \\
\text { importado } \\
\text { Mais rentável investir em atividade } \\
\text { de longa maturação }\end{array}$ \\
\hline & & Baixar taxas de juros & $\begin{array}{l}\text { Mais rentávcl investir cm agricultura } \\
\text { Menos rentável usar capital } \\
\text { importado }\end{array}$ \\
\hline & $\begin{array}{l}\text { Financiar atividade } \\
\text { estatal }\end{array}$ & Impostos/ Orçamento & $\begin{array}{l}\text { Garantir recursos para implementar } \\
\text { políticas de sustentabilidadc }\end{array}$ \\
\hline 2.Setorial & $\begin{array}{l}\text { Ajustar } \\
\text { relativos }\end{array}$ & $\begin{array}{l}\text { Eliminar controle de } \\
\text { preços de alimentos } \\
\text { Crédito subsidiado para } \\
\text { pratica sustentável } \\
\text { Taxar água de irrigação } \\
\text { Não subsidiar desmate e } \\
\text { agroquímicos } \\
\text { Evitar construir estradas } \\
\text { de colonização } \\
\text { F. Subsidiar replantio de } \\
\text { florestas naturais }\end{array}$ & $\begin{array}{l}\text { Mais rentável investir em agricultura } \\
\text { Maior investimento em conservação } \\
\text { dos solos, culturas perenes, etc... } \\
\text { Uso mais eficiente da água } \\
\text { Menor desmatamento } \\
\text { Uso mais racional de agroquímicos } \\
\text { Reduzir o desmatamento em áreas } \\
\text { de colonização }\end{array}$ \\
\hline 3.Modelo jurídico & $\begin{array}{l}\text { Reorientação no } \\
\text { uso dos recursos }\end{array}$ & $\begin{array}{l}\text { Titulação de terras e } \\
\text { garantia de propricdade } \\
\text { Criar áreas protegidas } \\
\text { rcspcitando populaçõcs } \\
\text { locais } \\
\text { Leis de patrimônio } \\
\text { genético } \\
\text { Leis sobre uso de } \\
\text { praguicidas } \\
\text { Ordenamento territorial }\end{array}$ & $\begin{array}{l}\text { Maior investimento em atividades de } \\
\text { longa maturação } \\
\text { Conservação de solos e da } \\
\text { biodivcrsidadc } \\
\text { Maior investimento na conservação } \\
\text { da diversidade genética } \\
\text { Uso mais racional de praguicidas } \\
\text { Conservação do recurso solo }\end{array}$ \\
\hline $\begin{array}{l}\text { 4. Políticas contra a } \\
\text { pobreza }\end{array}$ & $\begin{array}{l}\text { Melhorar o acesso } \\
\text { às oportunidades }\end{array}$ & Criação de empregos & $\begin{array}{l}\text { População mais consciente do } \\
\text { problema } \\
\text { Incorporação da população no } \\
\text { manejo dos recursos } \\
\text { Reduzir pressão para impedir que se } \\
\text { realizem atividades depredadoras do } \\
\text { ambiente }\end{array}$ \\
\hline
\end{tabular}

Fonte: Trigo et al. (1994) 
Apêndice 4: Áreas cultivadas no mundo

\begin{tabular}{lccc}
\hline \multirow{2}{*}{ Área e Uso de terras no Mundo } & 1980 & 1990 & 1996 \\
\cline { 2 - 4 } & \multicolumn{3}{c}{ Área em hectare x 1000 } \\
\hline Área Total & 13.399 .739 & 13.399 .739 & 13.387 .019 \\
Área de Terra & 13.043 .693 & 13.043 .644 & 13.048 .407 \\
Área arável + Culturas permanentes & 1.428 .833 & 1.499 .949 & 1.511 .330 \\
Área arável & 1.328 .479 & 1.381 .983 & 1.381 .917 \\
Culturas permanentes & 100.354 & 117.966 & 129.413 \\
Não cultiváveis & 11.614 .850 & 11.543 .695 & 11.537 .077 \\
\hline Fonte: FAO (1998) Yearbook Production vol. 51 1997. FAO Statistics Series $\mathrm{n}^{\circ} 142$ \\
Rome, 1998 241p.
\end{tabular}

Apêndice 5: Cenários de consumo e estrutura do abastecimento

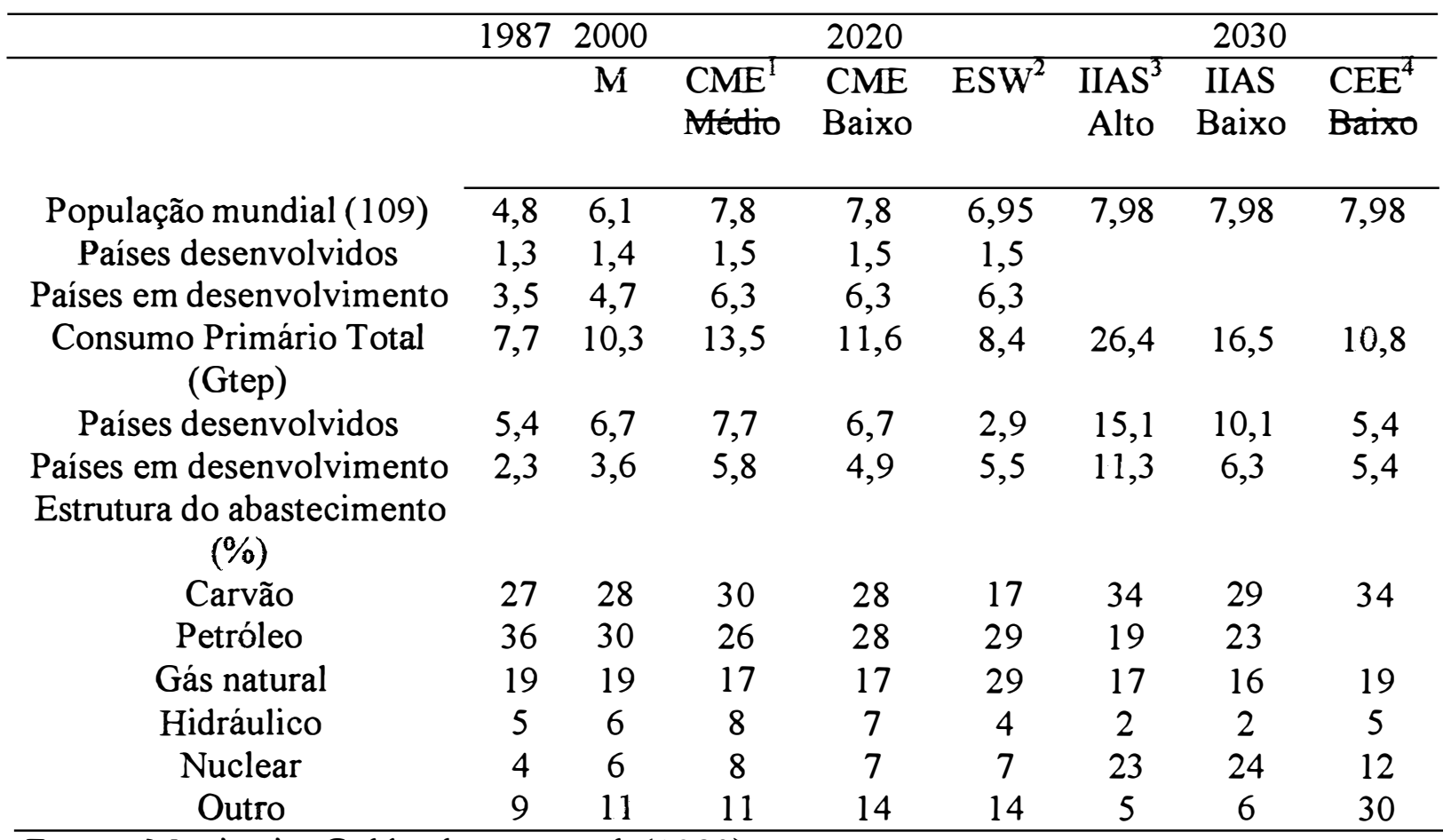

Fontes: Martin cita Goldemberg, J. et al. (1989)

${ }^{1} \mathrm{CME}=$ Conferência Mundial da Energia

${ }^{2}$ IIASA = International Institut for Applied System Analysis

${ }^{3} \mathrm{ESW}=$ Energy for a Sustainable World

4 CEE 
Apêndice 6: Cenários de consumo

\begin{tabular}{ccc}
\hline & $\begin{array}{c}\text { Cenário C do WEC } \\
(2020)\end{array}$ & $\begin{array}{c}\text { RIGES } \\
(2025)\end{array}$ \\
\hline Combustíveis fósseis & 6,2 & 5,82 \\
Sólido & 2,1 & 2,00 \\
Liquido & 2,7 & 1,72 \\
Gasoso & 2,4 & 2,1 \\
Nuclear & 0,7 & 0,33 \\
Renováveis & 3,4 & 5,02 \\
Hidreletricidade & 0,9 & 0,68 \\
Novos renováveis & 1,4 & -- \\
Intermitentes & -- & 0,84 \\
Tradicionais & 1,1 & -- \\
Nova biomassa & -- & 3,3 \\
H2 Solar & -- & 0,2 \\
Geotérmico & -- & 0,04 \\
Total & 11,3 & 11,21 \\
\hline Fonte: Goldemberg (1998) cita World Energy Council e Renewable Intensive Global \\
Energy Scenarios (RIGES) &
\end{tabular}

Apêndice7: Consumo per capita de energia em diferentes regiões

\begin{tabular}{|c|c|c|c|c|}
\hline & \multicolumn{2}{|c|}{1970} & \multicolumn{2}{|c|}{1990} \\
\hline Região & $\begin{array}{c}\text { Consumo de } \\
\text { Energia }\end{array}$ & Per capila & $\begin{array}{l}\text { Consumo de } \\
\text { Energia }\end{array}$ & Per capila \\
\hline & hexajoules & $\begin{array}{l}\text { Gigajoules por } \\
\text { pessoa }\end{array}$ & hexajoules & $\begin{array}{l}\text { Gigajoules por } \\
\text { pessoa }\end{array}$ \\
\hline $\begin{array}{c}\text { Países em } \\
\text { desenvolvimento }\end{array}$ & 30 & 12 & 84 & 21 \\
\hline $\begin{array}{c}\text { Países } \\
\text { Industrializados }\end{array}$ & 129 & 180 & 154 & 185 \\
\hline $\begin{array}{l}\text { Países do Leste } \\
\text { europeu }\end{array}$ & 44 & & 72 & 167 \\
\hline TOTAL & 203 & 55 & 310 & 59 \\
\hline
\end{tabular}

Fonte: ONU, World population prospects 1990 
Apêndice 8: Energia dispendida em diversas atividades

\begin{tabular}{llll}
\hline TRABALHO LEVE & \multicolumn{3}{l}{ TRABALHO MODERADO } \\
\hline Escrever & 20 & Dormir & $45-110$ \\
Ficar relaxado & 20 & Tomar banho & $125-215$ \\
Datilografar & 55 & Carpintaria & $150-180$ \\
Tocar violino & $40-50$ & Caminhar & $130-240$ \\
Lavar louça & 60 & & \\
Passar ferro & 60 & & \\
Geral: 300 & & Geral : 400 \\
\hline TRABALHO PESADO & \multicolumn{4}{l}{ TRABALHO MUITO PESADO } \\
\hline Marchar & $280-400$ & Pedreiro & 350 \\
Andar de bicicleta & $180-600$ & Correr & $800-1000$ \\
Remar & $120-600$ & Escalar & $400-900$ \\
Nadar & $200-700$ & Esquiar & $500-950$ \\
Geral: 500 & & Subir escadas & 1000 \\
\hline
\end{tabular}

Fonte: Pimentel (1974); Cook(1976)

Apêndice 9: Custo energético de alguns defensivos de uso agrícola

\begin{tabular}{cccc}
\hline & $\mathrm{MJ} / \mathrm{kg}$ & $\mathrm{Kcal} / \mathrm{kg}$ & $\mathrm{kcal} / \mathrm{g}$ \\
\hline MCPA & 127,7 & 30,52 & 0,031 \\
Diuron & 274,5 & 65607,07 & 65,607 \\
Atrazina & 188,3 & 45004,78 & 45,005 \\
Trifluralina & 150,9 & 36065,97 & 36,066 \\
Paraquat & 459,4 & 109799,24 & 109,799 \\
$2,4-\mathrm{D}$ & 87 & 20793,50 & 20,793 \\
$2,4,5-\mathrm{T}$ & 135 & 32265,77 & 32,266 \\
Dicamaba & 295 & 70506,69 & 70,507 \\
Glifosate & 454 & 108508,60 & 108,509 \\
Diquat & 400 & 95602,29 & 95,602 \\
Captan & 115 & 27485,66 & 27,486 \\
Carbofuran & 454 & 108508,60 & 108,509 \\
\hline
\end{tabular}

Fonte: Flück \& Baird (1982) 
Apêndice 10: Energia para diferentes combustíveis

\begin{tabular}{lcccc}
\hline Fontes: & Pimentel (1980) & Serra (1979) & Cook (1976) & Mello (1986) \\
\cline { 2 - 5 } Gasolina & 10.110 & 11.110 & --- & 9.449 \\
Diesel & 11.414 & 10.900 & --- & 10.358 \\
Álcool & -- & --- & 7.100 & --- \\
Eletricidade & $2.863 \mathrm{kcal} / \mathrm{kwh}$ & --- & --- & --- \\
\hline
\end{tabular}

Apêndice 11: Combustivel demandado em função do implemento

\begin{tabular}{|c|c|c|}
\hline OPERAÇÃO & $\begin{array}{c}\text { Combustivel } \\
\text { Demandado } \\
(\mathrm{MJ} / \mathrm{ha})\end{array}$ & $\begin{array}{c}\text { Combustível } \\
\text { Demandado } \\
\text { kcal/ha }\end{array}$ \\
\hline Preparo do Solo & & \\
\hline \multicolumn{3}{|l|}{ Arado de Discos ( $18 \mathrm{~cm}$ profundidade) } \\
\hline Solo leve & $125-250$ & $29875-59750$ \\
\hline Solo médio & $210-370$ & $50190-88430$ \\
\hline solo pesado & $320-665$ & $76480-158935$ \\
\hline Disco (8-13 $\mathrm{cm}$ de profundidade) & $105-235$ & $25095-56165$ \\
\hline $\begin{array}{c}\text { Arado de aivecas ( } 18-23 \mathrm{~cm} \text { de profundi//) } \\
\text { Grade }\end{array}$ & $115-530$ & $27485-126670$ \\
\hline tandem leve & $55-110$ & $13145-26290$ \\
\hline Tandem pesado & $110-185$ & $26290-44215$ \\
\hline Denteada & $10-35$ & $2390-8365$ \\
\hline $\begin{array}{c}\text { Enxada Rotativa ( } 8-10 \mathrm{~cm} \text { profundi//) } \\
\text { Semeadura }\end{array}$ & $370-745$ & \\
\hline Disco para grãos & $15-55$ & $3585-13145$ \\
\hline \multicolumn{3}{|l|}{ Aplicadores Químicos } \\
\hline Aplicador de NH3 & $65-95$ & $15535-23422$ \\
\hline Pulverizador & $0,3-0,6$ & $71,7-143,4$ \\
\hline Pulverizador amplo & $3-6$ & $717-1434$ \\
\hline \multirow{2}{*}{\multicolumn{3}{|c|}{$\begin{array}{l}\text { Colheita de grãos } \\
\text { Colhedora }\end{array}$}} \\
\hline & & \\
\hline Milho & $260-390$ & $62140-93210$ \\
\hline Grãos pequenos & $105-320$ & $25095-76480$ \\
\hline Colheita de forragens & $\mathrm{MJ} / \mathrm{t}$ & \\
\hline Forragens verdes & $10-30$ & $2390-7170$ \\
\hline Silagem de milho & $20-50$ & $4780-11950$ \\
\hline
\end{tabular}

Fonte: Loomis \& Connor (1996) 
Apêndice 12: Tempo de operação na produção de cereais sob vários sistemas (h/ha)

\begin{tabular}{cccc}
\hline & \multicolumn{3}{c}{ Sistema de Produção } \\
\hline Operação & Manual & Tração Animal & Mecanizado \\
\cline { 2 - 4 } Preparo de Solo & $500-1000$ & & \\
Enxada & & $16-27$ & 2 \\
Arado & & $3-5$ & 0,5 \\
Grade & $2-4$ & & \\
Semeadura & 10 & $1-6$ & 0,5 \\
A lanço & 2 & $1-2$ & 0,3 \\
Máquina & 65 & $3-5$ & 1 \\
Fertilização & $4-5$ & 2 & 0,5 \\
Controle de Daninhas & & & \\
Capina Manual & & & \\
Pulverização & 1000 & 500 & 2 \\
Colheita & & & \\
Fenação & & & \\
Máquina & & & \\
Colhedora & & &
\end{tabular}

Fonte: Loomis \& Connor (1996).

(1) Baseado em uma colheita de 6 t/ha.

Apêndice 13: Desgaste de máquinas por hora trabalhada

\begin{tabular}{lccc}
\hline MÁQUINA/IMPLEMENTO & Peso em kg & Vida útil em horas & Kg/hora* \\
\hline TRATOR 60 HP & 4700 & 8084 & 0,58 \\
TRATOR 70 HP & 4400 & 8081 & 0,54 \\
TRATOR 80 HP & 5300 & 8625 & 0,61 \\
TRATOR 100 HP & 7100 & 8082 & 0,88 \\
ARADO DE DISCOS & 800 & 1223 & 0,65 \\
GRADE DE DISCOS TANDEM & 2100 & 1223 & 1,72 \\
ARADO DE AIVECAS & 800 & 1223 & 0,65 \\
PULVERIZADOR & 200 & 700 & 0,29 \\
SEMEADORA - ADUBADORA & 1000 & 734 & 1,36 \\
ENXADAS ROTATIVAS & 400 & 1223 & 0,33 \\
\hline
\end{tabular}

Fonte: Pimentel (1980) 
Apêndice 14: Energia direta em diversas formas de transporte

\begin{tabular}{cccc}
\hline \multicolumn{4}{c}{ Custo energético do Transporte } \\
\hline MJ $/ \mathrm{t} . \mathrm{km}$ & $\mathrm{kcal} / \mathrm{t} . \mathrm{km}$ & $\mathrm{kcal} / \mathrm{kg} . \mathrm{km}$ \\
Ferroviário & 0,540 & 129,063 & 0,129 \\
Rodoviário & 1,780 & 425,430 & 0,425 \\
Fluvial & 0,370 & 88,432 & 0,088 \\
\hline
\end{tabular}

Fonte: Hirst (1973) citado por Fluck \& Baird (1982)

Apêndice 15: Custo energético de diferentes matérias primas

\begin{tabular}{ccc}
\hline Matéria - prima & \multicolumn{3}{c}{ Energia } \\
\hline Alumínio & 262,00 & $\mathrm{kcal} / \mathrm{kg}$ \\
Aço & 46,40 & 62619,50 \\
Papel & 23,40 & 11089,87 \\
Plásticos & 9,52 & 5592,73 \\
Madeira & 2,50 & 2275,33 \\
Pedra brita e cascalho & 0,07 & 597,51 \\
Cimento Portland & 9,30 & 16,97 \\
Polietileno & 108,70 & 2222,75 \\
\end{tabular}

Fonte: Flück \& Baird (1982)

Apêndice 16: Energia contida em algumas substâncias

\begin{tabular}{llc}
\hline Substância & Fórmula & Calor por grama (kcal) \\
Metano & $\mathrm{CH}_{4}$ & 13,2 \\
Óleo & & 10,0 \\
Lipídio & $\mathrm{C}_{57} \mathrm{H}_{104} \mathrm{O}_{6}$ & 9,1 \\
Carbono (carvão) & $\mathrm{C}$ & 7,8 \\
Álcool etílico & $\mathrm{C}_{2} \mathrm{H}_{6} \mathrm{O}$ & 7,1 \\
Proteína & $\mathrm{C}_{1864 \mathrm{H}_{3012} \mathrm{O}_{576} \mathrm{~N}_{468} \mathrm{~S}_{21}}$ & 5,7 \\
Glicose & $\mathrm{C}_{6} \mathrm{H}_{12} \mathrm{O}_{6}$ & 4,1 \\
\hline Fonte: Cook (1976) & &
\end{tabular}


Apêndice 17: Teores de proteína e valores calóricos para diversos produtos

\begin{tabular}{|c|c|c|}
\hline PRODUTO & Kcal $/ \mathrm{kg}$ & Proteína $(\mathrm{g} / \mathrm{kg})$ \\
\hline Abacate & 1.620 & 18 \\
\hline Alface & 130 & 9 \\
\hline Amendoim & 5.300 & 285 \\
\hline Arroz & 3.504 & 81 \\
\hline Banana & 1.200 & 15 \\
\hline Batata & 920 & 17 \\
\hline Bovinos & 2.503 & 187 \\
\hline Brócoli & 370 & 33 \\
\hline Café & 2.355 & 135 \\
\hline Cana & 640 & 5 \\
\hline Carne de Frango & 1.067 & 197 \\
\hline Carne de Peixe & 860 & 192 \\
\hline Cenoura & 500 & 12 \\
\hline Centeio & 3.413 & 91 \\
\hline Chuchu & 913 & 25 \\
\hline Couve - flor & 300 & 25 \\
\hline Feijão & 3.370 & 215 \\
\hline Girassol & 5.843 & 254 \\
\hline Laranja & 526 & 5 \\
\hline Leite & 630 & 31 \\
\hline Mamão & 680 & 2 \\
\hline Mandioca & 1.470 & 20 \\
\hline Milho & 3.610 & 89 \\
\hline Ovos & 1.630 & 123 \\
\hline Repolho & 250 & 14 \\
\hline Silagem & 3.090 & 80 \\
\hline Soja & 4.000 & 340 \\
\hline Tomate & 200 & 10 \\
\hline Trigo & 3.440 & 110 \\
\hline
\end{tabular}

Fonte: Franco (1989)

Apêndice 18: Custo energético, por hectare irrigado, para irrigação de $915 \mathrm{~mm}$

\begin{tabular}{llllllll}
\hline \multicolumn{7}{c}{ Mcal/915 mm irrigados } \\
\hline Superficie & \multicolumn{1}{c}{0} & \multicolumn{1}{c}{5} & \multicolumn{1}{c}{10} & \multicolumn{1}{c}{20} & \multicolumn{1}{c}{50} & \multicolumn{1}{c}{75} & 100 \\
\cline { 2 - 8 } Gotejamento & 818,2 & 1000 & 1181,8 & 1454,5 & 2454,5 & 3272,72 & 4000 \\
Aspersão/pivot & 2454,5 & 2636,4 & 2818,18 & 3000 & 4000 & 4818,2 & 5636,4 \\
& 3090,9 & 3272,7 & 3454,5 & 3818,2 & 4909,1 & 5818,2 & 6727,3 \\
\hline
\end{tabular}

Fonte: ${ }^{1}$ Fluck \& Baird (1982) 
Apêndice 19: Energia direta utilizada para o recalque

\begin{tabular}{ccccc}
\hline Recalque & $\begin{array}{c}\text { MJ } \\
\text { (energia direta) }\end{array}$ & kcal & $\begin{array}{c}\text { Diesel (l) } \\
\text { 30\% de eficiência }\end{array}$ & kcal \\
\hline 10 & 14 & 3346 & 1,21 & 13.443 \\
50 & 70 & 16730 & 6,07 & 67.438 \\
100 & 140 & 33460 & 12,14 & 134.875 \\
200 & 280 & 66920 & 24,28 & 269.751 \\
300 & 420 & 100380 & 36,42 & 404.626 \\
\hline
\end{tabular}

Fonte: Pimentel (1980)

Apêndice 20: Energia empregada em diferentes sistemas de irrigação

\begin{tabular}{lcc}
\hline Sistema/energia & MJ/ha.ano & kcal/ha.ano \\
\hline Superficie (terra) & 466 & 111.374 \\
Superficie (condutos) & 1219 & 291.341 \\
Aspersão & 6018 & 1.438 .302 \\
Pivot & 1074 & 256.686 \\
Gotejamento & 4215 & 1.007 .385 \\
\hline
\end{tabular}

Fonte: Pimentel (1980)

Apêndice 21: Radiação solar média em função da época e latitude

\begin{tabular}{ccc}
\hline Paralelo & Primavera - Verão & Outono - Inverno \\
\hline $0-10$ & \multicolumn{2}{c}{ kcal/hectare/dia } \\
$10-20$ & 500 & 400 \\
$20-30$ & $400-500$ & $300-400$ \\
$30-40$ & $500-600$ & $200-300$ \\
$40-50$ & $500-600$ & $100-200$ \\
$50-60$ & $400-500$ & $0-100$ \\
Média & $300-400$ & 0 \\
\hline
\end{tabular}

Fonte: Mota (1981) 